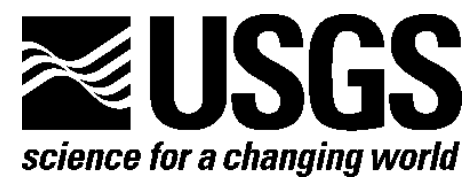

Plant Distributions in the Southwestern United States: A Scenario Assessment of the Modern-Day and Future Distribution Ranges of 166 Species

By Kathryn A. Thomas, Patricia P. Guertin, and Leila Gass

Open-File Report 2012-1020

U.S. Department of the Interior

U.S. Geological Survey 


\section{U.S. Department of the Interior \\ KEN SALAZAR, Secretary}

\section{U.S. Geological Survey \\ Marcia K. McNutt, Director}

U.S. Geological Survey, Reston, Virginia: 2012

For more information on the USGS-the Federal source for science about the Earth,

its natural and living resources, natural hazards, and the environment,

visit http://www.usgs.gov or call 1-888-ASK-USGS.

For an overview of USGS information products, including maps, imagery, and publications, visit http://www.usgs.gov/pubprod

To order this and other USGS information products, visit http://store.usgs.gov

Suggested citation:

Thomas, K.A., Guertin, P.P., and Gass, L., 2012, Plant distributions in the southwestern United States; a scenario assessment of the modern-day and future distribution ranges of 166 species: U.S. Geological Survey Open-File Report 2012-1020, 83 p. and 166-page appendix, available at http://pubs.usgs.gov/of/2012/1020/.

Any use of trade, product, or firm names is for descriptive purposes only and does not imply endorsement by the U.S. Government.

Although this report is in the public domain, permission must be secured from the individual copyright owners to reproduce any copyrighted material contained within this report. 


\section{Contents}

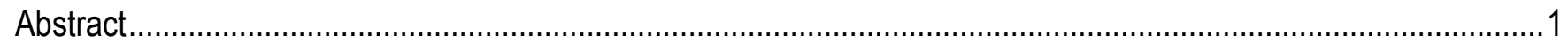

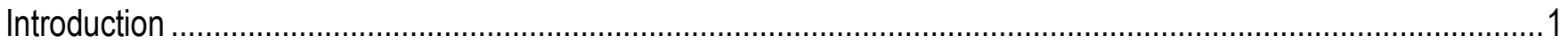

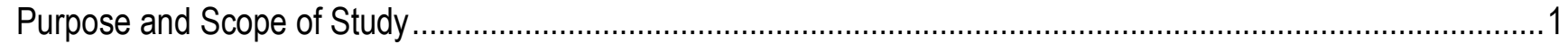

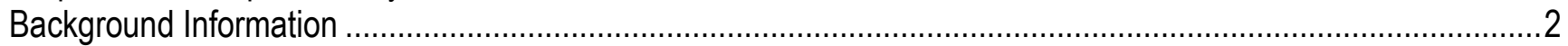

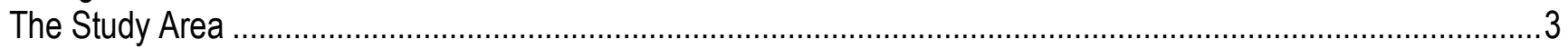

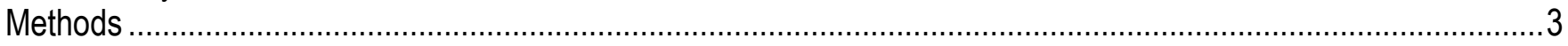

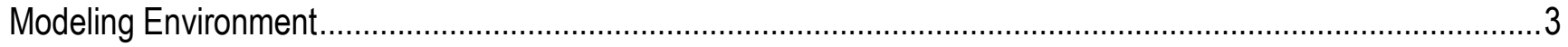

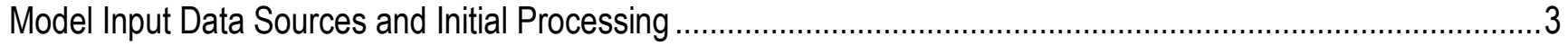

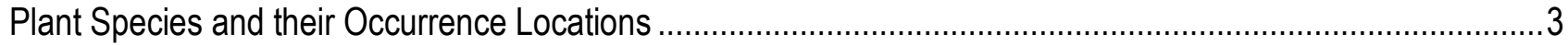

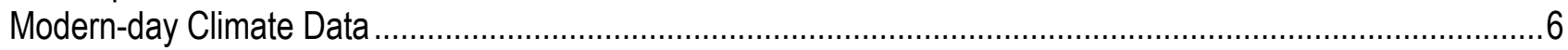

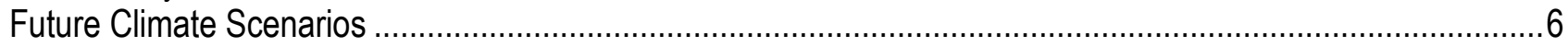

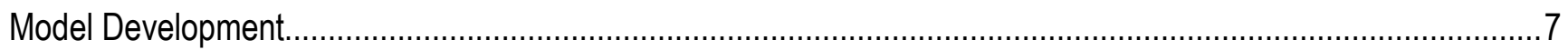

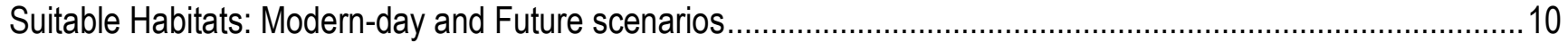

Model Agreement for Suitability Classes ...........................................................................................

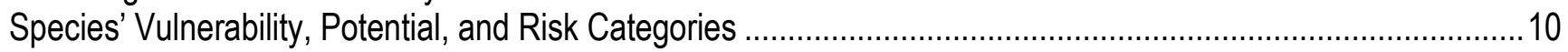

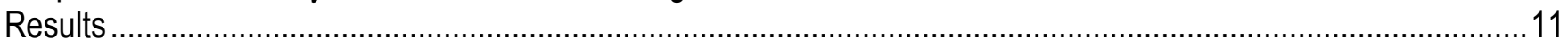

Model Performance Metrics.........................................................................................................

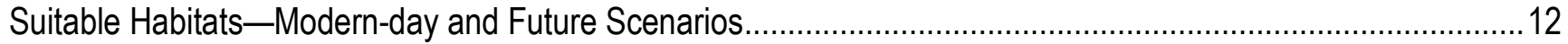

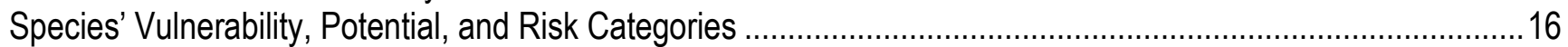

Species Vulnerability to Loss of Modern-day Suitable Habitat...................................................................16

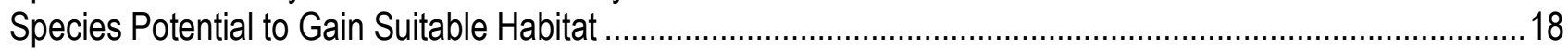

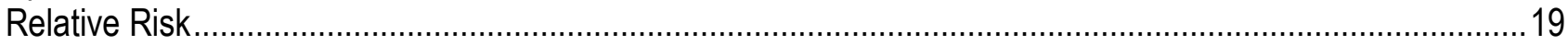

Summary and Discussion ……………………………

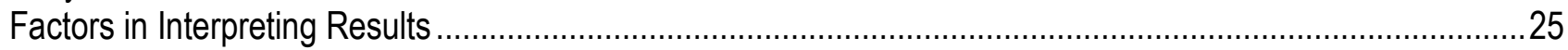

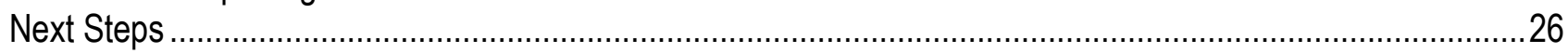

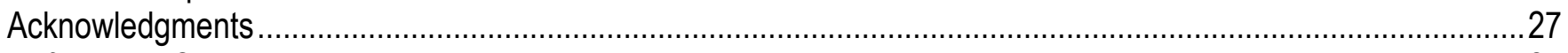

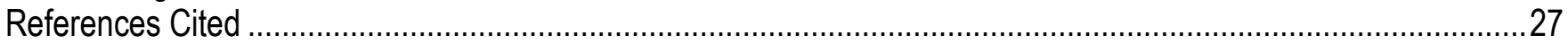

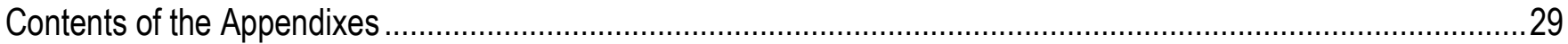

Appendix A Assessment results for the 166 plant species: Summary tables ..................................................2

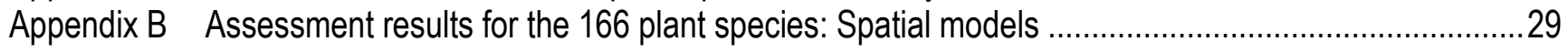

Appendix A Assessment Results for the 166 Plant Species: Summary Tables ...................................................

Appendix B Assessment Results for the 166 Plant Species: Spatial Models Figures 1 to 166 . .................................83

\section{Figures}

1. Map showing Southwest study area and ecoregions............................................................................

2. Example of map results reported for each species in appendix B ............................................................. 15 


\section{Tables}

1. Field studies supplying species' location data.

2. 2007 Intergovernmental Panel on Climate Change scenarios represented by Climate Wizard climate grids and used to predict future suitable habitat.

3. General circulation models incorporated into Climate Wizard climate grids used to predict future suitable habitat.

4. Climate scenarios used to predict suitable habitat for modern-day and future conditions.

5. Future suitable habitat $(\mathrm{SH})$ suitability classes and their relations to modern-day and future model suitability predictions.

6. Species were assigned to one of nine risk categories that represented three levels of vulnerability to loss of modern-day habitat and three levels of potential to gain of new habitat.

7. An illustrative subsection of summary data presented in appendix A, table 1 .

8. An illustrative subsection of summary data presented in appendix A, table 2 .

9. The average percentage and standard deviation for tree, shrub, and grass species of the total area predicted for each suitability class by all three model results concurrently to the total areas predicted by all three combined.

10. An illustrative subsection of summary data presented in appendix A, Model agreement for future suitable habitat.

11. An illustrative subsection of summary data presented in appendix A, table 4 for the suitable habitat (SH) vulnerability and potential scores for a species.

12. Assignment of tree species to risk categories.

13. Assignment of shrub species to risk categories. 21

14. Assignment of grass species to risk categories. 


\title{
Plant Distributions in the Southwestern United States: A Scenario Assessment of the Modern-day and Future Distribution Ranges of 166 Species
}

\author{
By Kathryn A. Thomas, Patricia P. Guertin, and Leila Gass
}

\section{Abstract}

The authors developed spatial models of the predicted modern-day suitable habitat (SH) of 166 dominant and indicator plant species of the southwestern United States (herein referred to as the Southwest) and then conducted a coarse assessment of potential future changes in the distribution of their suitable habitat under three climate-change scenarios for two time periods. We used Maxent-based spatial modeling to predict the modern-day and future scenarios of SH for each species in an over 342million-acre area encompassing all or parts of six states in the Southwest-Arizona, California, Colorado, Nevada, New Mexico, and Utah. Modern-day SH models were predicted by our using 26 annual and monthly average temperature and precipitation variables, averaged for the years 1971-2000. Future SH models were predicted for each species by our using six climate models based on application of the average of 16 General Circulation Models to Intergovernmental Panel on Climate Change emission scenarios B1, A1B, and A2 for two time periods, 2040 to 2069 and 2070 and 2100, referred to respectively as the 2050 and 2100 time periods.

The assessment examined each species' vulnerability to loss of modern-day SH under future climate scenarios, potential to gain SH under future climate scenarios, and each species' estimated risk as a function of both vulnerability and potential gains. All 166 species were predicted to lose modernday SH in the future climate change scenarios. In the 2050 time period, nearly 30 percent of the species lost 75 percent or more of their modern-day suitable habitat, 21 species gained more new SH than their modern-day SH, and 30 species gained less new SH than 25 percent of their modern-day SH. In the 2100 time period, nearly half of the species lost 75 percent or more of their modern-day SH, 28 species gained more new SH than their modern-day SH, and 34 gained less new SH than 25 percent of their modern-day SH. Using nine risk categories we found only two species were in the least risk category, while 20 species were in the highest risk category. The assessment showed that species respond independently to predicted climate change, suggesting that current plant assemblages may disassemble under predicted climate change scenarios.

This report presents the results for each species in tables (Appendix A) and maps (14 for each species) in Appendix B.

\section{Introduction}

\section{Purpose and Scope of Study}

Rapidly changing climate predicted for the 21 st century may profoundly affect population sizes and distribution of biota (Solomon and others, 2007). Species may respond differentially to new climate 
patterns depending upon their individual response to changes in temperature and precipitation, among other factors. Concerned policymakers, resource managers, and the public are interested in having the best possible understanding of the sorts of ecological and biogeographical changes that may result. As a response to that need, the author's assessed potential changes in the geographic location of suitable habitat of dominant and indicator plant species in the arid and semi-arid Southwest, resulting from climate change.

This study is unique, because it evaluates plant response using three different climate change scenarios, presenting a range of potential climate windows under which a plant's habitat may be defined. The report documents the methods used to develop spatial models of SH for 166 plant species, both for modern-day and predicted future climate, and conducts an assessment of each species' vulnerability to loss of $\mathrm{SH}$, potential to gain $\mathrm{SH}$, and overall risk under different climate change scenarios. While overall results are discussed in the report body the appendices provide summary results for each plant, both in table and map format. These data provide resources for researchers and resource managers in the Southwest to examine how SH for plants may change in their area of concern or responsibility and to take account of uncertainty in future climate predictions. The data also provide a basis for predicting how entire ecosystems may respond to future climate change. The approach taken here can be applied to other geographic areas with the use of plant occurrence, modern-day climate data, and future climate predictions appropriate to that area.

\section{Background Information}

The general prediction for climate change in the Southwest is for warmer temperatures and a more arid climate (Seager and others, 2007: Overpeck and Udall, 2010). The Southwest supports a high proportion of public lands that are managed, in part or fully, for their biological diversity (Ernst and others, 2007), highlighting the need for information about the potential response of species in order to inform future conservation management decisions. Studies on potential shifts in distribution ranges of suitable habitat for plants in the Southwest have been limited. Shafer and others (2001) modeled the future simulated distribution of plant species in western North America, including some species in the Southwest, and predicted areas with no change, contraction, or extension of the species distribution. Cole and others $(2007,2011)$ focused on the predicted response of single species, Pinus edulis and Yucca brevifolia, and incorporated analysis of their potential to migrate to new suitable habitat.

Predictive modeling is one tool to assess the potential geographic response of species to future climate change. One regional approach is to examine how the distribution of modern-day SH of a species compares to predictions of the species' SH under future climate scenarios. Spatial redistribution of a species' SH in the future, due to changing climate, provides an estimate of the geographic "footprint" of habitat potentially available to the species for new occupation, without consideration of other edaphic, dispersal, or biological factors that may influence the species' actual occupancy. Comparing modern-day with predicted future SH provides a view of potential new habitats (increased $\mathrm{SH}$ ), modern-day habitats that may become less suitable for the species (decreased $\mathrm{SH}$ ), and modernday habitats that may remain suitable (maintained $\mathrm{SH}$ ). In addition, predictions of SH by our using different future climate scenarios illustrate the range of potential distribution shifts for a species regardless of which climate scenario actually develops.

We developed a spatial model of each species' modern-day SH based on annual and monthly average temperature and precipitation from 1971 to 2000 . These models represent the climatic envelope of SH habitat within which individuals of a species may occur where soil, microclimate, and biotic interactions are favorable. Individuals of a species will not occur at every location within the $\mathrm{SH}$. We developed spatial models of the potential future locations of the modern-day SH for three different climate change models over two time periods. The climate models represented the average of 16 
General Circulation Models applied to the 2007 Intergovernmental Panel on Climate Change (AR4) emission scenarios B1, A1B, and A2 (Solomon and others, 2007). The time periods were 2040 to 2069 and 2070 and 2100 , referred to respectively as the 2050 and 2100 time periods. We chose these climate models, because they were freely available and represent breadth of possible climate change currently predicted for the Southwest. Rather than attempting to choose one scenario that might be more applicable to the Southwest, we assess the potential range of SH predictions that might occur using different climate change predictions. We examined the certainty of model results by evaluating the area as maintained, decreasing, or increasing SH by one, two, or all three models for each time period.

We assessed the regional vulnerability of each of the 166 plants to potential future loss of SH by determining the proportion of predicted modern-day SH that becomes unsuitable under future climate change projections. We assessed the possibility of the species to adapt to changing climate by expanding into new SH by determining the proportional area of new SH that might become available for occupation compared to the area of the species' modern-day SH. Finally we examined the relative risk to the species over the 2050 time period using nine risk categories to classify the relations of the species' vulnerability to loss of SH and potential to gain SH. For all three assessments, we averaged the three climate-change-model results for each time period.

\section{The Study Area}

The study area consisted of all or parts of six southwestern states. We used the ecoregion units originally defined by Bailey (1995) and modified by The Nature Conservancy (unpub. data, 2005) to select areas within the six states that are part of major Southwest ecoregions (fig.1). The total study area for development of models was 342,098,664 acres (138,442,418 ha) and included all of Arizona and Utah, the majority of Nevada and New Mexico, the western part of Colorado, and the far eastern areas of California. Fourteen ecoregions are represented in all or part within the study area. Of these, six have 90 percent or more of their area within the study area-Arizona-New Mexico Mountains, Colorado Plateau, Great Basin, Mojave Desert, Southern Rocky Mountains, and Utah High Plateaus.

\section{Methods}

\section{Modeling Environment}

We used ESRI ArcGIS 9.2 and 9.3 to prepare data for model input and to process model output data. The study area was represented by a raster grid comprised of 1,945,672 standardized cells and with Albers NAD83 projection. We refer to this grid in this report as the standard grid as it was used to standardize all input data to the same extent, cell size $\left(843.5 \mathrm{~m}^{2}\right)$, and projection.

\section{Model Input Data Sources and Initial Processing}

\section{Plant Species and their Occurrence Locations}

We compiled a list of dominant and/or indicator native tree, shrub, and grass species and their presence locations from 30 field studies, each consisting of multiple observation sites, conducted throughout the study area (table 1). The studies selected met the following criteria: (1) each plant or site location was georeferenced and had an accuracy of at least $+/-100 \mathrm{~m}$; (2) the study was no older than 1990; and (3) the study listed, at the minimum, all dominant and associate perennial plants at each site. Nonnative species were not included as they are not normally considered dominant and/or indicator species in Southwest vegetation and the field studies did not systematically sample nonnative species. 

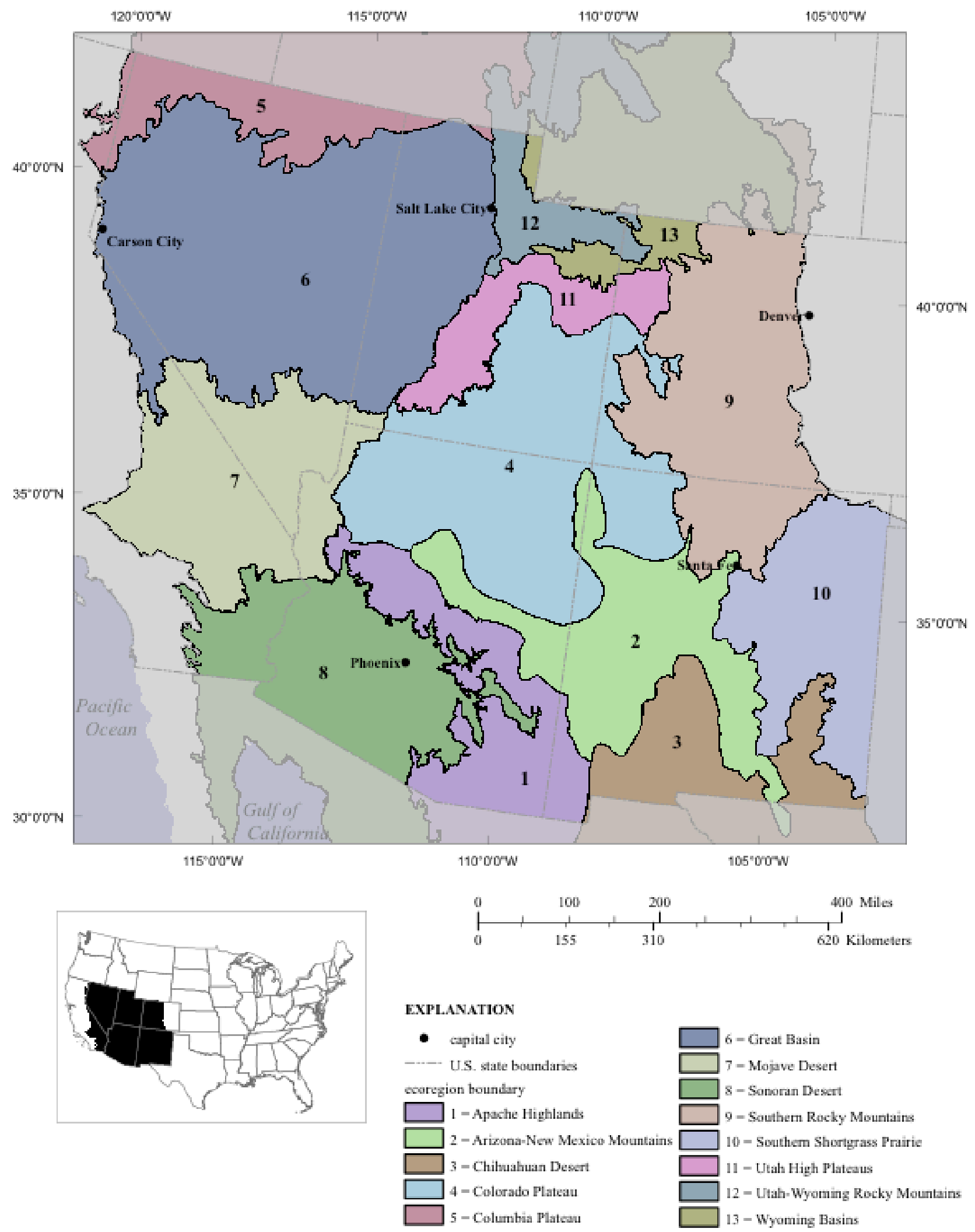

Figure 1. Map showing Southwest study area and ecoregions. 
Collectively the occurrence data documented on the sites in these studies represented the breadth of the study area and, although not designed to sample all environments within the study area, the studies included many remote environments. However, the sites did not appear to adequately represent wetland and riparian habitats, so dominant and indicator species for these habitats were not included as part of the target species.

Table 1. Field studies supplying species' location data.

\begin{tabular}{|c|c|}
\hline State & Study Name \\
\hline Arizona & USGS, Arizona Gap Analysis (First Generation) \\
\hline Arizona & USGS, Babbitt Ranches, Arizona - Benchmark Assessment \\
\hline Arizona & USGS, Field Studies Petrified Forest National Park, Arizona \\
\hline Arizona & NAU, Juniper Dataset, Arizona \\
\hline Arizona & USGS, SWReGAP - Arizona Field Observations \\
\hline Arizona & USGS/NPN Park Mapping, Sunset Crater National Monument \\
\hline Arizona & USGS/NPN Park Mapping, Tuzigoot National Monument \\
\hline Arizona & USGS/NPN Park Mapping, Walnut Canyon National Monument \\
\hline Arizona & USGS/NPN Park Mapping, Wupatki National Monument \\
\hline Arizona & $\begin{array}{l}\text { USGS/NPS Park Mapping Canyon de Chelly National Monument, } \\
\text { Arizona }\end{array}$ \\
\hline Arizona & USGS/NPS Park Mapping Petrified Forest National Park, Arizona \\
\hline California & 29 Palms - California, Field Survey \\
\hline California & 29 Palms, California - Range Survey \\
\hline California & CA Natural Heritage Vegetation Study, California \\
\hline California & USGS, Coaxil Cable Study, California \\
\hline California & Death Valley Tortoise Habitat Survey, California \\
\hline California & Field Survey (Watts) - California \\
\hline California & USGS, Field transects, California \\
\hline California & Ft. Irwin Vegetation Survey, California \\
\hline California & USGS, Mojave Desert Ecosystem Study, California \\
\hline California & USGS, Mojave Pipeline Study, California \\
\hline California & USGS, Owlshead Vegetation Study, California \\
\hline Colorado & SWReGAP - Colorado Field Observations \\
\hline Colorado & USGS/NPS Park Mapping Mesa Verde National Park, Colorado \\
\hline Nevada & Nevada Test Site Studies (Oestler), Nevada \\
\hline Nevada & SWReGAP - Nevada Field Observations \\
\hline Nevada & Yucca Mtn. Vegetation Study, Nevada \\
\hline New Mexico & SWReGAP - New Mexico Field Observations \\
\hline Utah & SWReGAP - Utah Field Observations \\
\hline Utah & USGS/NPN Park Mapping Program, Zion National Park \\
\hline
\end{tabular}


We used NatureServe Explorer (http://www.natureserve.org/explorer/) to define which species were dominant or an indicator for Southwest ecological systems. We used the Integrated Taxonomic Information System (ITIS, http:/www.itis.gov/) as the taxonomic authority for plant nomenclature. The final species list was comprised of 36 tree, 97 shrub, and 33 grass species.

We compared the occurrence records for each species to the standard grid and chose the centroid of each grid cell in which the species occurred to represent the location of that record. Where multiple occurrence records for a species occurred in a single standard grid cell, they were all represented by the same centroid. Any species with less than 50 centroids was not included in the analysis. The number of species' centroids for each species ranged from 51 (Rhus ovata) to 10,139 (Artemisia tridentata); see appendix A, table 1 for the number of centroids available for each species and the common name of each species. We used 128,619 species by location centroids overall.

\section{Modern-day Climate Data}

The available spatially interpolated climate data consisted of average precipitation and temperature (minimum and maximum), both monthly and annually, for the years 1971-2000. We obtained these data from the online Parameter-elevation Regressions on Independent Slopes Model (PRISM) datasets (Prism Climate Group 2004). The PRISM data represent temperature in Celsius and precipitation in millimeters, each multiplied by 100 . The native cell resolution of the PRISM data was maintained $\left(843.5 \mathrm{~m}^{2}\right)$ and was used to define the cell resolution of the standard grid. We obtained PRISM data in ASCII format for the entire continental United States and used the standard grid as an input mask to extract PRISM data for the study area.

Development of future SH models required input of the same type of climate variables as used to develop the modern-day SH models. As the downscaled data available for future SH models (see below) expressed average precipitation and temperature on a monthly and annual basis, we averaged the minimum and maximum PRISM data to convert these to an average value. The processed PRISM data contained 26 modern-day climate variables comprised as average precipitation (12 monthly and 1 annual) and average temperature (12 monthly and 1 annual).

\section{Future Climate Scenarios}

Future SH models were based on climate models of future temperature and precipitation developed by the Climate Wizard collaboration (http://www.climatewizard.org/) of The Nature Conservancy, The University of Washington, and The University of Southern Mississippi. We ran six future climate scenarios that were based on three AR4 emission scenarios (table 2) for the years 2040 2069 (the 2050 time period) and the years 2070-2099 (the 2100 time period). The emission scenarios represented low (B1), medium (A1B), and high (A2) projected future global temperature increases as described by the 2007 IPPC report (Solomon and others, 2007). Each emission scenario describes a potential "story-line" based on assumptions of how economic, technological, and population growth might develop in the future. Each Climate Wizard model consisted of an ensemble of the nonparametric quantile-rank average of the median values of all 16 general circulation models (GCM, table 3) applied to each of the three emission scenarios. The scenario data for monthly and annual temperature and precipitation had been statistically downscaled at $12 \mathrm{~km}$ resolution and were available for the entire USA in ASCII format. Temperature was represented in degrees Fahrenheit and precipitation in inches.

We used the standard grid as an input mask to extract the downloaded temperature and precipitation data for each scenario for the study area. A nearest neighbor algorithm was used during the extraction to resample the $12-\mathrm{km}$ native grid cell size to the standard grid cell size of $843 \mathrm{~m}^{2}$; note, this step did not increase the resolution of the downscaled climate scenarios. The temperature grids were converted from degrees Fahrenheit to degrees Celsius and the precipitation grids were converted from 
inches to millimeters. All values were multiplied by 100 so that they were in equivalent units to the PRISM data.

Table 2. 2007 Intergovernmental Panel on Climate Change scenarios represented by Climate Wizard climate grids and used to predict future suitable habitat.

\begin{tabular}{l|l}
\hline \multicolumn{1}{c|}{$\begin{array}{c}\text { Emission } \\
\text { Scenario }\end{array}$} & \multicolumn{1}{c}{ Description } \\
\hline & $\begin{array}{l}\text { Low population growth, service/information economy, clean and } \\
\text { efficient technologies, global temperature change estimated to be } \\
\text { B1 }\end{array}$ \\
\hline & $\begin{array}{l}\text { Low population growth, rapid economic growth, new and efficient } \\
\text { technologies, global temperature change estimated to be } 28^{\circ} \mathrm{C} \\
\left(1.7-4.4^{\circ} \mathrm{C} \text { range }\right)\end{array}$ \\
A1B & $\begin{array}{l}\text { High population growth, regional economic development, } \\
\text { technologies changing slowly, global temperature change } \\
\text { estimated to be } 3.4^{\circ} \mathrm{C}\left(2-5.4^{\circ} \mathrm{C} \text { range }\right)\end{array}$ \\
\hline
\end{tabular}

\section{Model Development}

We used the freely available maximum-entropy-based algorithm Maxent version 3.3.1 (Phillips and others, 2006; Elith and others, 2011) to create modern-day SH models and project future SH models. Maxent has been shown to be a high-performing approach to species distribution modeling (Phillips and others, 2009; Elith and others, 2006) and is designed to deal with "presence-only" occurrence datasets. Each "run" of Maxent requires input sample files, environmental layers files, and projection layer files. We used a "samples with data" or SWD input format because the environmental input layers and projection layer files were large. The default logistic output was maintained, which results in each unit (grid cell) of the predictive output files to consist of scores in a continuous range between 0 and 1 . These scores represent the relative probability of presence of the species in that unit.

Sample files: A sample file was created for each species consisting of the geographic coordinates for the species' centroids and the values of the modern-day climate data at each centroid. We used an ArcGIS shapefile of each species' centroid to extract the modern-day climate data for the centroids from the processed PRISM data. The table of species' centroid locations and corresponding climate data for each species was converted to comma delimited (.csv) format for input into Maxent.

"Background" Data: SWD requires a single input file of "background" locations and their respective modern-day climate values. We selected 10,000 random background centroids from the standard grid and added the geographic coordinates to each. We then extracted the modern-day climate data for each background centroid from the processed PRISM data and converted the resulting tables of background points and their respective climate variables to ASCII format for input in Maxent.

Projection Layers Files: Seven sets of projection layers files were developed, the modern-day climate conditions and the six future climate scenarios (table 4). We extracted the data for each standardized grid cell for the 26 climate variables for each modern-day or future scenario into tables and converted the values to ASCII format. Each projection layer set thus consisted of 26 ASCII files representing monthly average temperature (12 files), monthly average precipitation (12 files), yearly average temperature (1 file), and yearly average precipitation (1 file). 
Table 3. General circulation models incorporated into Climate Wizard climate grids used to predict future suitable habitat.

\begin{tabular}{|c|c|}
\hline Acronym & Origin \\
\hline BCCR-BCM2.0 & $\begin{array}{l}\text { Bjerknes Centre for Climate Research, University of Bergen, } \\
\text { Norway }\end{array}$ \\
\hline CGCM3.1(T47) & $\begin{array}{l}\text { Canadian Centre for Climate Modelling \& Analysis, Climate } \\
\text { Research Branch, Environment Canada }\end{array}$ \\
\hline CNRM-CM3 & $\begin{array}{l}\text { Centre National de Recherches Métérologigues, Météo } \\
\text { France, France }\end{array}$ \\
\hline CSIRO-Mk3.0 & CSIRO Atmospheric Research, Australia \\
\hline GFDL-CM2.0 & $\begin{array}{l}\text { National Oceanic and Atmospheric } \\
\text { Administration/Geophysical Fluid Dynamics Laboratory, } \\
\text { United States }\end{array}$ \\
\hline GFDL-CM2.1 & $\begin{array}{l}\text { National Oceanic and Atmospheric } \\
\text { Administration/Geophysical Fluid Dynamics Laboratory, } \\
\text { United States }\end{array}$ \\
\hline GISS-ER & $\begin{array}{l}\text { US National Aeronautics and Space Administration/ Goddard } \\
\text { Institute for Space Studies, United States }\end{array}$ \\
\hline INM-CM3.0 & $\begin{array}{l}\text { Institute for Numerical Mathematics, Russian Academy of } \\
\text { Science, Russia }\end{array}$ \\
\hline IPSL-CM4 & $\begin{array}{l}\text { Institut Pierre Simon Laplace, Center for Climate System } \\
\text { Research, France }\end{array}$ \\
\hline MIROC3.2 & $\begin{array}{l}\text { Center for Climate System Research, University of Tokyo; } \\
\text { National Institute for Environmental Studies; and Frontier } \\
\text { Research Center for Global Change, Japan Agency for } \\
\text { Marine-Earth Science and Technology }\end{array}$ \\
\hline ECHO-G & $\begin{array}{l}\text { Meteorological Institute of the University of Bonn, Germany; } \\
\text { Meteorological Research Institute of KMA, Korea; and Model } \\
\text { and Data Group }\end{array}$ \\
\hline $\begin{array}{l}\text { ECHAM5/MPI- } \\
\text { OM }\end{array}$ & Max Planck Institute for Meteorology, Germany \\
\hline MRI-CGCM2.3.2 & $\begin{array}{l}\text { Meteorological Research Institute, Japan Meteorological } \\
\text { Agency, Japan }\end{array}$ \\
\hline CCSM3 & National Center for Atmospheric Research, United States \\
\hline PCM & National Center for Atmospheric Research, United States \\
\hline UKMO-HadCM3 & $\begin{array}{l}\text { Hadley Centre for Climate Prediction and Research/ Met } \\
\text { Office, United Kingdom }\end{array}$ \\
\hline
\end{tabular}

Model Runs: We used the sample layer file for each species, the background layer file, and each of the projection layer files (table 4) as input to Maxent to develop the modern-day and future $\mathrm{SH}$ models for each of the 166 species. Modern-day SH models were tested in two ways within Maxent. Maxent automatically calculates a performance measure, the receiver operating characteristic (ROC) area under curve (AUC) metric, for the input sample data. An AUC value of 1 indicates perfect model performance, 0.5 a random prediction, and lower than 0.5 is worse than random (Elith and others, 2006). For the first model run, we used settings on Maxent to randomly divide the sample data into a test data set (20 percent) and a training dataset ( 80 percent) to obtain two AUC scores (test and training). For the second run, we incorporated all sample data for calculation of only a training AUC score. 
Table 4. Climate scenarios used to predict suitable habitat for modern-day and future conditions. Two runs were made for modern-day - one (test) with 20 percent of the data withheld from the training dataset for a test of model performance and the second with all data included in the training data set.

\begin{tabular}{c|c}
\hline $\begin{array}{c}\text { Run } \\
\text { Number }\end{array}$ & Scenario \\
\hline 1 & Modern-day - test \\
\hline 2 & Modern-day - main run \\
\hline 3 & B1 2050 \\
\hline 4 & A1B 2050 \\
\hline 5 & A2 2050 \\
\hline 6 & B1 2100 \\
\hline 7 & A1B 2100 \\
\hline 8 & A2 2100 \\
\hline
\end{tabular}

Each species had eight SH model runs (table 4): the modern-day with 20 percent test data withheld, the modern-day with no test data withheld, one for each of the three scenarios for the 2050 time period, and one for each of the three scenarios for the 2100 time period. We used the modern-day SH model with no sample data withheld as input for each of the future SH projections; the modern-day SH model with 20 percent test data was used only to test the model performance. The initial raw ASCII output for each prediction was converted to a raster grid with Albers Nad83 projection. The raster grids expressed SH with cell values ranging continuously from 0 to 1 (continuous models), with 0 indicating the lowest predictive certainty.

A breakpoint of 0.5 was applied to the raster model output to convert the continuous output values to binary representing unsuitable and suitable habitat. This 0.5 breakpoint is known as the default or conventional threshold (Franklin, 2009). A number of threshold approaches have been proposed. For example, Franklin (2009) lists 12 approaches in addition to the default approach. While Liu and others (2005) in a study comparing the performance of different approaches to determining the threshold breakpoint did not recommend the default method, Freeman and Moisen (2008) found the default method produces equally useful results when model performance is high and prevalence is not low. Prevalence is the proportion of sampled sites where a species is present (Santika, 2011).

To apply the threshold, we reclassified the predicted cell values to $<0.5=0,0.5-1.0=1$, where 0 indicated unsuitable habitat and 1 indicated suitable habitat. We conducted a second performance evaluation after applying the threshold by calculating for each model the number of centroids correctly identified as SH for the species. This check was used to estimate prevalence where all sample locations for the species were taken as the known occurrences and the number predicted correctly was used to determine the prevalence proportion, and where:

Overall threshold accuracy $=$ no. species' centroids correctly predicted as suitable/ no. all species' centroids

We used the same threshold levels to convert the continuous grid output to binary for the future $\mathrm{SH}$ models output, but we assigned a different reclassification value in preparation for the $\mathrm{SH}$ change assessment. We reclassified the predicted cell values for future SH models as $<0.5=10$ and $0.5-1.0=$ 20 , where 10 indicated unsuitable habitat and 20 indicated SH. Whereas modern-day SH model output had a continuous ( 0 to 1 cell values, relative probability) and a binary ( 0 or 1 cell values, unsuitable or suitable) representation, the future SH models had only binary representation of unsuitable or suitable (10 or 20 cell values). 


\section{Suitable Habitats: Modern-day and Future scenarios}

The modern-day binary-SH models for each species were added to each of the future binary-SH models for that species (using map algebra in ArcGIS's Spatial Analyst) to create six change grids, one for each of the future climate scenarios. A unique cell value of 10,11, 20, or 21 was assigned to each cell depending on the values of its constituent modern-day suitability and future suitability cell values (table 5).

A count of cells for each category was extracted for each species and was used to calculate four metrics for each species for each scenario:

1) Percent $\mathrm{SH}$ modern-day $=$ no. cells suitable $\mathrm{SH} /$ no. cells study area

2) Percent Maintained $\mathrm{SH}$ future $=$ no. cells maintained $\mathrm{SH} /$ no. cells $\mathrm{SH}$ modern-day

3) Percent Increased SH future $=$ no. cells increased SH /no. cells SH modern-day

4) Percent Decreased SH future $=$ no. cells decreased suitability SH /no. cells SH modernday

Table 5. Future suitable habitat (SH) suitability classes and their relations to modern-day and future model suitability predictions. Each suitability class represents the relation of $\mathrm{SH}$ in the future predictions compared to the $\mathrm{SH}$ in the modern-day prediction. The suitability classes were applied numerically to each standard grid cell.

\begin{tabular}{r|l|l|c}
\hline Future SH suitability class & $\begin{array}{c}\text { Modern-Day binary-SH } \\
\text { model cell value }\end{array}$ & \multicolumn{1}{|c}{$\begin{array}{c}\text { Future binary-SH } \\
\text { model cell value }\end{array}$} & $\begin{array}{c}\text { Future SH } \\
\text { model cell } \\
\text { value }\end{array}$ \\
\hline maintained unsuitability & 0 (unsuitable) & 10 (unsuitable) & 10 \\
\hline decreased suitability & 1 (suitable) & 10 (unsuitable) & 11 \\
\hline increased suitability & 0 (unsuitable) & 20 (suitable) & 20 \\
\hline maintained suitability & 1 (suitable) & 20 (suitable) & 21 \\
\hline
\end{tabular}

\section{Model Agreement for Suitability Classes}

To determine the certainty of each future SH model, we deconstructed each change grid into three grids representing each of the suitability classes in the change grid. For each component grid the suitability class represented - maintained, increased, or decreased - was reclassified to 1 and otherwise 0 . Next all grids for a suitability class, regardless of scenario, were combined for each time period. For each species, the scenario model agreement score was calculated as the number of cells in a suitability grid with $0,1,2$, or 3 grids predicting that suitability class. The raw count for each total was converted to a percent of all cells predicted for that suitability class in the grid. For the results where all three models agreed, we calculated the average percent and standard deviation for all trees, shrubs and grasses respectively

\section{Species' Vulnerability, Potential, and Risk Categories}

We developed a metric to represent each species' vulnerability to decreases in modern-day SH under changing climate that was based on the proportion of modern-day SH that is predicted to decrease for each time period. Decreases in SH were averaged for all three scenarios per time period:

\section{Vulnerability to loss $=$ Average area $\mathrm{SH}$ decreased/Modern-day area $\mathrm{SH}$}

We also developed a metric for the species' potential for adaptation under changing climate for each time period due to gain in $\mathrm{SH}$, using the average area for all three scenarios predicted as increased $\mathrm{SH}$ : 
Potential for gain = Average area SH increased suitability/Modern-day area SH

To examine the relative risk to each species we divided the vulnerability scores into three levels representing low, moderate to high, or very high predicted loss of modern-day SH. The thresholds for the three vulnerability level were assigned using the following breaks in the vulnerability scores:

Low loss: 0 to 0.25

Moderate to high: $>0.25$ to $\leq 0.75$

Very high : $>0.75$ to 1.00

We also divided the potential scores into three levels to represent predicted gain in SH in the future. The two potential levels were assigned with the following breaks in the potential scores:

Very high: $\geq 0.75$

Moderate to high: $>0.25$ and $<0.75$

Low: $0-0.25$

A very high potential score indicates that predicted future gains in SH are greater in area than the area of modern-day SH. On the other hand, a low potential score indicates that predicted future gains in $\mathrm{SH}$ are less than 25 percent in the area of modern-day SH. The combination of the levels of the vulnerability and potential categories created nine risk categories (table 6). This risk analysis was conducted only for the 2050 time period predictions.

\section{Results}

The data summaries (tables) and maps of model output described below appear for all 166 species in the two appendices to this report. Below, we report on the results considering all 166 species in aggregate. We also present representative results for five species from appendix A and one figure from appendix B to illustrate the results for each species available in the appendices.

\section{Model Performance Metrics}

Maxent generates an AUC performance score during each model run. Three AUC scores were obtained for the prediction of modern-day SH for each species: (1) AUC for 20 percent test data withheld, (2) AUC for the 80 percent remaining training data, and (3) AUC with no withheld data. AUC scores were consistently high for model performance: (1) 20 percent test, range of 0.828-0.998, (2) 80 percent training, range of $0.837-0.973$, and (3) no withheld training, range of $0.836-0.999$. Based on guidelines described by Swets (1988), AUC values above 0.9 are highly accurate and between 0.7 and 0.9 are useful. Of the 166 species models with no withheld training points, 154 had AUC scores above 0.9 . The other 12 species had AUC scores above 0.828. The individual scores for each species are listed in appendix A, table 1, and illustrated on table 7. 
Table 6. Species were assigned to one of nine risk categories that represented three levels of vulnerability to loss of modern-day habitat and three levels of potential to gain of new habitat.

\begin{tabular}{|c|c|c|c|}
\hline & \multicolumn{3}{|c|}{ Potential score } \\
\hline & Very high (>1.00) & $\begin{array}{l}\text { Moderate to High }(>0.25 \\
\text { and } \leq 0.75)\end{array}$ & Low (0-0.25) \\
\hline Low (0-.25) & $\begin{array}{l}\text { Species will maintain } 75 \\
\text { percent or more of modern- } \\
\text { day SH and will gain double } \\
\text { or more SH in the future. }\end{array}$ & $\begin{array}{l}\text { Species will maintain } 75 \\
\text { percent or more of } \\
\text { modern-day SH and will } \\
\text { gain } 25 \text { to } 75 \text { percent new } \\
\text { SH in the future. }\end{array}$ & $\begin{array}{l}\text { Species will maintain } 75 \\
\text { percent or more of } \\
\text { modern-day SH and will } \\
\text { gain } 0 \text { to } 25 \text { percent new } \\
\text { SH in the future. }\end{array}$ \\
\hline $\begin{array}{l}\text { Moderate to high } \\
(>0.25 \text { to } \leq 0.75)\end{array}$ & $\begin{array}{l}\text { Species will maintain } 25 \text { to } \\
75 \text { percent of modern-day } \\
\text { SH and will gain double or } \\
\text { more SH in the future. }\end{array}$ & $\begin{array}{l}\text { Species will maintain } 25 \\
\text { to } 75 \text { percent of modern- } \\
\text { day SH and will gain } 25 \text { to } \\
75 \text { percent new SH in the } \\
\text { future. }\end{array}$ & $\begin{array}{l}\text { Species will maintain } 25 \\
\text { to } 75 \text { percent of modern- } \\
\text { day SH and will gain } 0 \text { to } \\
25 \text { percent new SH in the } \\
\text { future. }\end{array}$ \\
\hline $\begin{array}{l}\text { Very high }(>0.75 \\
\text { to } 1.00)\end{array}$ & $\begin{array}{l}\text { Species will maintain less } \\
\text { than } 25 \text { percent of modern- } \\
\text { day SH and will gain double } \\
\text { or more SH in the future. }\end{array}$ & $\begin{array}{l}\text { Species will maintain less } \\
\text { than } 25 \text { percent of } \\
\text { modern-day SH and will } \\
\text { gain } 25 \text { to } 75 \text { percent new } \\
\text { SH in the future. }\end{array}$ & $\begin{array}{l}\text { Species will maintain less } \\
\text { than } 25 \text { percent of } \\
\text { modern-day SH and will } \\
\text { gain } 0 \text { to } 25 \text { percent new } \\
\text { SH in the future. }\end{array}$ \\
\hline
\end{tabular}

A performance metric was calculated for the overall accuracy of using a threshold of 0.50 to convert the continuous model output to binary. The choice of this threshold was successful in capturing 72.7 to 97.1 percent of the species' centroids used for each species (appendix A, table 1). This test was used as an estimate of prevalence and supported the use of the threshold using the criteria of Freeman and Moisen (2008).

\section{Suitable Habitats-Modern-day and Future Scenarios}

The proportion of the study area predicted as modern-day SH ranged from 0.3 to 31.5 percent among the species (appendix A, table 2; illustrated table 8). Species with the greatest proportion of the study area of predicted SH were Artemisia tridentata (31.5 percent), Gutierrezia sarothrae (28.3 percent), Juniperus osteosperma (22.2 percent), Achnatherum hymenoides (21.6 percent), and Bouteloua gracilis (20.4 percent). An additional 18 species have predicted modern-day SH proportion between 10 and 20 percent. Forty-eight species had greater than 5 percent but less than 10 percent predicted modern-day SH proportion of the study area. Only three species had predicted modern-day SH of less than 1 percent: Tetradymia spinosa (0.9 percent), Lupinus argenteus (0.7 percent), and Pinus strobiformis (0.3 percent).

The geographic location of predicted modern-day SH for each of the 166 species is represented by a map of the continuous values (appendix B, insert map A; illustrated on fig. 2, insert map A) and the binary representation (Appendix B, insert map B; illustrated on fig. 2, insert map B). 
Table 7. An illustrative subsection of summary data presented in appendix A, table 1. For each species the table lists its scientific and USDA PLANTS code, number of locations for each species used to develop predicted modern-day and future climate models, and model performance metrics. AUC indicates the receiver operator curve area under curve statistic. The standardized centroids for each species were randomly divided into a test data set containing 20 percent of the data (AUC20) and a training dataset with the remaining 80 percent (AUC20 training). All standardized centroids were incorporated in the second model run (AUC all training). The overall threshold accuracy score indicates the number of species' centroids correctly predicted as suitable using the 50 percent threshold criterion divided by the total number of centroids for the species.

\begin{tabular}{|c|c|c|c|c|c|c|c|}
\hline Species & 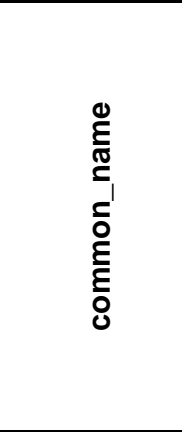 & 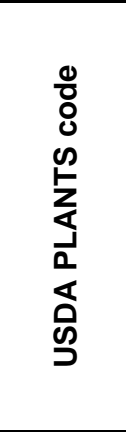 & 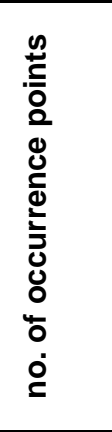 & 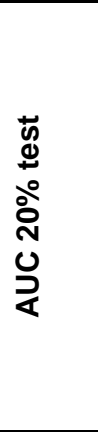 & 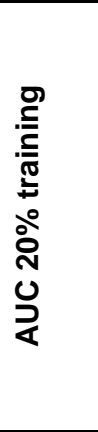 & 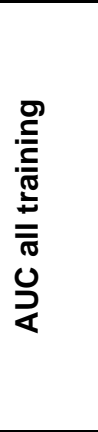 & 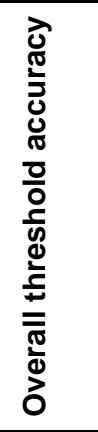 \\
\hline \multicolumn{8}{|l|}{ Trees } \\
\hline Pinus flexilis & limber pine & PIFL2 & 255 & 0.957 & 0.986 & 0.985 & 0.894 \\
\hline Yucca brevifolia & Joshua tree & YUBR & 470 & 0.977 & 0.989 & 0.988 & 0.913 \\
\hline \multicolumn{8}{|l|}{ Shrubs } \\
\hline Artemisia tridentata & $\begin{array}{l}\text { big } \\
\text { sagebrush }\end{array}$ & ARTR2 & 10139 & 0.834 & 0.843 & 0.839 & 0.874 \\
\hline \multicolumn{8}{|l|}{ Grasses } \\
\hline Bouteloua gracilis & blue grama & BOGR2 & 4538 & 0.899 & 0.902 & 0.901 & 0.838 \\
\hline
\end{tabular}

All species experienced a reduction of modern-day SH under the future scenarios. For scenario B1, the proportion of modern-day SH maintained in the future ranged from 0.5 to 90.8 percent for 2050 time period, and from 0 to 74.5 percent for the 2100 time period. For scenario A1B, the range was 0 to 78.0 percent for the 2050 period and 0 to 84.3 percent for the 2100 period. For scenario A2, the range was 0.6 to 90.4 percent and 0 to 74.2 percent for the respective time periods. Each species' predicted future SH is illustrated in appendix B for the 2050 period scenarios (B1, insert map C; A1B, insert map D; A2, insert map E) and for the 2100 period scenarios (B1, insert map F; A1B, insert map G; A2, insert map $\mathrm{H}$; illustrated fig. 2, insert maps $\mathrm{C}-\mathrm{H}$ ).

\section{Model Agreement for Suitability Classes}

Areas with all three models agreeing for a suitability class have the most certainty. The average percent agreement was highest for areas predicted to decrease in suitability, with the scores slightly higher for the 2100 time period (69.0-70.8 percent) than the 2050 time period (63.5-66.6 percent), table 9 . Average percentages were noticeably lower for the areas predicted to maintain or increase suitability. The lowest agreement was for the areas predicted to increase in suitability in the 2100 time period (19.6-30.7 percent). Overall, scores for trees were higher than scores for grasses; and scores for both trees and grasses were higher than scores for shrubs. The standard deviation was high for all averaged percentages indicating species predicted response was highly variable with respect to the climate change model used. 
Table 8. An illustrative subsection of summary data presented in appendix A, table 2. For each species, the table shows its predicted modern-day proportion of the study area (S) and the percent of the modern-day suitable habitat (SH) predicted to be decreasing suitability (DS), increasing suitability (IS), and maintained suitability (MS). The future scenarios were B1 (global temperature rise of $2.4^{\circ} \mathrm{C}$ ), A1B (global temperature rise of $2.8^{\circ} \mathrm{C}$ ), and $\mathrm{A} 2$ (global temperature rise of $3.4^{\circ} \mathrm{C}$ ) for the time period 2050 (2040-2069) and 2100 (2070-2100).

\begin{tabular}{|c|c|c|c|c|c|c|c|c|}
\hline \multirow[b]{3}{*}{ Species } & \multirow[b]{2}{*}{ 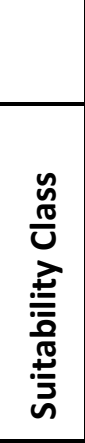 } & \multirow[b]{2}{*}{$\begin{array}{l}\text { Predicted } \\
\text { modern-day } \\
\text { SH ( percent } \\
\text { of study } \\
\text { area) }\end{array}$} & \multicolumn{6}{|c|}{$\begin{array}{l}\text { Predicted future SH (percent of modern-day SH area) by } \\
\text { scenario and time period }\end{array}$} \\
\hline & & & \multicolumn{2}{|c|}{ B1 (Low) } & \multicolumn{2}{|c|}{ A1B (Medium) } & \multicolumn{2}{|c|}{ A2 (High) } \\
\hline & & & 2050 & 2100 & 2050 & 2100 & 2050 & 2100 \\
\hline \multicolumn{9}{|l|}{ Trees } \\
\hline \multirow[t]{4}{*}{ Pinus flexilis } & $S$ & 4.1 & & & & & & \\
\hline & DS & & 86.4 & 95.8 & 94.5 & 95.7 & 95.9 & 98.7 \\
\hline & IS & & 20.4 & 8.8 & 11.1 & 19.2 & 5.1 & 6.5 \\
\hline & MS & & 13.6 & 4.2 & 5.5 & 4.3 & 4.1 & 1.3 \\
\hline \multirow[t]{4}{*}{ Yucca brevifolia } & $S$ & 3.9 & & & & & & \\
\hline & DS & & 72.3 & 88.6 & 75 & 84.8 & 60.1 & 94.9 \\
\hline & IS & & 46.3 & 31.1 & 99.3 & 139.9 & 108.1 & 53.4 \\
\hline & MS & & 27.7 & 11.4 & 25 & 15.2 & 39.9 & 5.1 \\
\hline \multicolumn{9}{|l|}{ Shrubs } \\
\hline \multirow[t]{4}{*}{$\begin{array}{l}\text { Artemisia } \\
\text { tridentata }\end{array}$} & $\mathrm{S}$ & 3.1 & & & & & & \\
\hline & DS & & 47.5 & 52.6 & 52.4 & 61.1 & 45.9 & 63.1 \\
\hline & IS & & 7.6 & 6.3 & 9.9 & 6.4 & 11 & 7.3 \\
\hline & MS & & 52.5 & 47.4 & 47.6 & 38.9 & 54.1 & 36.9 \\
\hline \multicolumn{9}{|l|}{ Grasses } \\
\hline \multirow[t]{4}{*}{ Pleuraphis mutica } & $\mathrm{S}$ & 5.0 & & & & & & \\
\hline & DS & & 80.4 & 88.9 & 85.5 & 96.6 & 85.5 & 98.3 \\
\hline & IS & & 87.1 & 92.1 & 120.7 & 71.1 & 92.7 & 106.2 \\
\hline & $\mathrm{MS}$ & & 19.6 & 11.1 & 14.5 & 3.4 & 14.5 & 1.7 \\
\hline
\end{tabular}




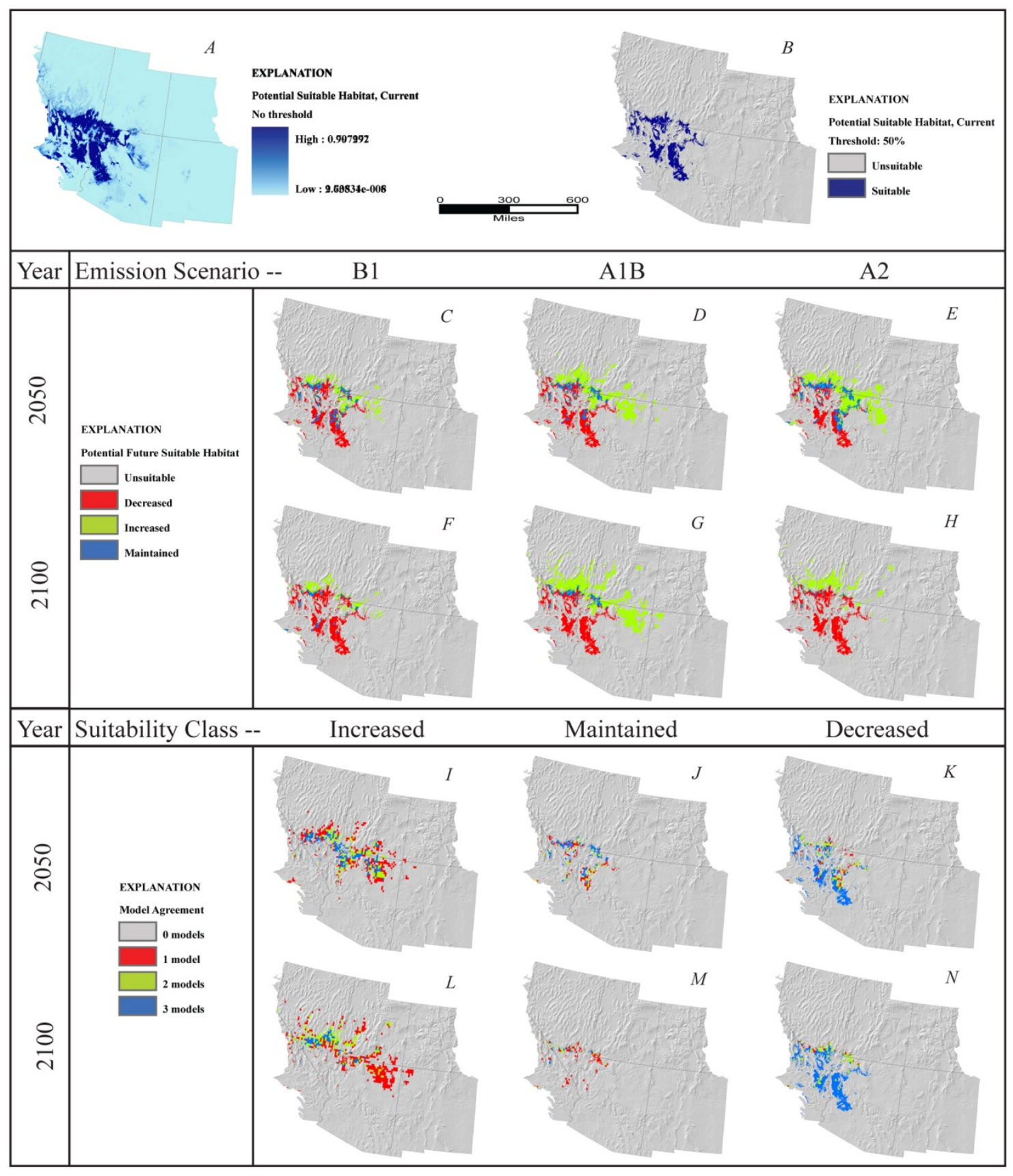

Figure 36. Yucca brevifolia. A, Potential suitable habitat for species based on average annual and monthly precipitation and temperature from 1971 to 2000, continuous model output with no threshold. B, Potential suitable habitat, binary output using .5 threshold. C-E, Potential suitable habitat predicted by year 2050 under emission scenario (C), B1, (D), A1B, (E), A2. F-H, Potential suitable habitat predicted by year 2100 under emission scenario (F), B1, (G), A1B, (H), A2. I-K, Number of 2050 emission scenario models predicting each suitability class, (I), increased suitability, $(\mathrm{J})$, maintained suitability, $(\mathrm{K})$, decreased suitability. L-N, Number of 2100 emission scenario models predicting each suitability class, (L), increased suitability, (M), maintained suitability, and $(\mathrm{N})$, decreased suitability.

Figure 2. Example of map results reported for each species in appendix B. 
Table 9. The average percentage and standard deviation for tree, shrub, and grass species of the total area predicted for each suitability class by all three model results concurrently to the total areas predicted by all three combined. The three classes are (1) DS, decreased suitability; (2) IS, increased suitability; and (3) MS, maintained suitability.

\begin{tabular}{|c|c|c|c|c|c|c|}
\hline & \multicolumn{6}{|c|}{ Average percent $+l$ - standard error } \\
\hline & \multicolumn{3}{|c|}{2050} & \multicolumn{3}{|c|}{2100} \\
\hline & DS & IS & MS & DS & IS & MS \\
\hline Trees & $63.5+\mid-19.7$ & $35.0+1-17.9$ & $47.2+1-21.2$ & $69.3+\mid-18.6$ & $30.7+\mid-17.5$ & $39.4+\mid-21.1$ \\
\hline Shrubs & $66.6+\mid-16.4$ & $26.9+\mid-13.8$ & $40.4+/-19.7$ & $69.0+\mid-17.0$ & $19.6+\mid-14.0$ & $24.1+\mid-18.8$ \\
\hline Grasses & $64.5+\mid-14.5$ & $28.1+\mid-9.2$ & $43.1+\mid-13.4$ & $70.8+\mid-15.2$ & $22.3+\mid-11.6$ & $30.2+\mid-18.2$ \\
\hline
\end{tabular}

The spatial distributions of model agreement for each species-scenario are illustrated in appendix B (insert maps I-N) and the corresponding area metrics listed in appendix A, table 3. These results are also illustrated with figure 2, insert maps I-N, and table 10.

\section{Species' Vulnerability, Potential, and Risk Categories}

\section{Species Vulnerability to Loss of Modern-day Suitable Habitat}

Overall, vulnerability scores ranged from 0.215 (the least vulnerable) to 0.995 (the most vulnerable) in the 2050 time period and from 0.248 to 0.999 in the 2100 time period (appendix A, table 4; illustrated on table 11). By our using the vulnerability classes applied to the risk analysis, only two species had low vulnerability scores $(0-.25)$, indicating 75 percent or more of their modern-day SH was predicted to be SH in the future under the average of the scenarios. Only one tree had low vulnerability, Prosopis velutina, with low scores occurring in both the 2050 and 2100 time period. The shrub, Shepherdia canadensis, had low vulnerability in the 2050 time period but no shrubs had low vulnerability in the 2100 time period. None of the grasses had low vulnerability in either time period. Many species had vulnerability scores in the moderate to high range $(>0.25$ to $\leq 0.75)$ indicating 25 to 75 percent of their modern-day SH would become unsuitable in the future. Twenty-seven of the tree species ( 75.0 percent of the trees considered) were in this range in the 2050 time period and 21 (58.3 percent) in the 2100 time period. Sixty-five (67.0 percent) of the shrubs were in this category in the 2050 time period and 40 (41.2 percent) in the 2100 time period. The grass species had 25 ( 75.8 percent) in this category in the 2050 time period and 18 (54.5 percent) in the 2100 time period.

The species most vulnerable to loss of modern-day SH were identified as those with vulnerability scores of 0.75 or greater, indicating that 25 percent or less of their modern-day SH would be maintained in future climates. Eight trees (22.2 percent) were identified in this category for the 2050 time period: Fraxinus velutina, Juglans major, Quercus arizonica, Quercus grisea, Pinus aristata, Pinus flexilis, Pinus monophylla, and Pinus strobiformis. These trees and Abies concolor, Picea pungens, Pinus ponderosa, Populus angustifolia, Quercus emoryi, Quercus grisea, and Yucca brevifolia were identified as most vulnerable for the 2100 time period, a total of 15 or 41.7 percent of the tree species. Of the shrubs 33 (34.0 percent) were identified as highly vulnerable in the 2050 time period and 57 (57.6 percent) in the 2100 time period. These species are not listed here for space considerations, but are identified in appendix A, table 4. Eight grass species (24.2 percent) were very highly vulnerable in the 2050 time period: Achnatherum speciosum Achnatherum thurberianum, Festuca arizonica, Pleuraphis mutica, Pleuraphis rigida, Schizachyrium scoparium, Sporobolus cryptandrus, and 
Sporobolus flexuosus. These grass species with the addition of Bouteloua curtipendula, Bouteloua eriopoda, Elymus elymoides, Festuca brachyphylla, Leymus cinereus, Muhlenbergia montana, and Poa fendleriana comprise the 15 (45.5 percent) most vulnerable grasses in the 2100 time period.

Table 10. An illustrative subsection of summary data presented in appendix $A$, table 3 . For each species, the number of future suitable habitat $(\mathrm{SH})$ models predicting one of three classes is shown as a percent of the total area predicted for that class by the three climate models combined for each time period. The three classes are (1) DS, decreased suitability; (2) IS, increased suitability; and (3) MS, maintained suitability. The total area predicted for each class was the spatial area predicted concurrently for that class for each species using the 2007 IPPC scenarios B1 (global temperature rise of $2.4^{\circ} \mathrm{C}$ ), A1B (global temperature rise of $2.8^{\circ} \mathrm{C}$ ), and $\mathrm{A} 2$ (global temperature rise of $3.4^{\circ} \mathrm{C}$ ) for the time period 2050 (2040-2069) and 2100 (2070-2100).

\begin{tabular}{|c|c|c|c|c|c|c|c|}
\hline \multirow[t]{3}{*}{ Species } & \multirow{3}{*}{ 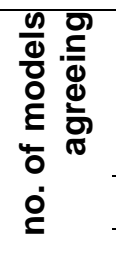 } & \multicolumn{6}{|c|}{$\begin{array}{l}\text { Model agreement for each suitable habitat class ( percent } \\
\text { of total area predicted for that suitability class) for two } \\
\text { time periods }\end{array}$} \\
\hline & & \multicolumn{3}{|c|}{2050} & \multicolumn{3}{|c|}{2100} \\
\hline & & DS & IS & MS & DS & IS & MS \\
\hline \multicolumn{8}{|l|}{ Trees } \\
\hline \multirow[t]{3}{*}{ Pinus flexilis } & 1 & 3.3 & 54.5 & 56.1 & 1.4 & 60.1 & 78.3 \\
\hline & 2 & 8.2 & 26.9 & 22.9 & 6.1 & 34.7 & 17.7 \\
\hline & 3 & 88.5 & 18.6 & 21.1 & 92.5 & 5.2 & 4 \\
\hline \multirow[t]{3}{*}{ Yucca brevifolia } & 1 & 13 & 47.4 & 36.8 & 4 & 60.5 & 68.5 \\
\hline & 2 & 20.5 & 26.6 & 23.3 & 15.4 & 28.3 & 17.9 \\
\hline & 3 & 66.5 & 26 & 39.9 & 80.6 & 11.3 & 13.6 \\
\hline Shrubs & & 0 & 0 & 0 & 0 & 0 & 0 \\
\hline \multirow[t]{3}{*}{ tridentata } & 1 & 17.6 & 32.2 & 15.5 & 21 & 35.7 & 35.4 \\
\hline & 2 & 16.2 & 22.8 & 16.8 & 28 & 19.8 & 26.5 \\
\hline & 3 & 66.2 & 45 & 67.6 & 51 & 44.5 & 38 \\
\hline Grasses & & 0 & 0 & 0 & 0 & 0 & 0 \\
\hline \multirow[t]{3}{*}{ Pleuraphis mutica } & 1 & 5.9 & 42.7 & 39.3 & 3.2 & 52.5 & 65.6 \\
\hline & 2 & 10.6 & 24.5 & 22.1 & 7.6 & 35.8 & 27.8 \\
\hline & 3 & 83.5 & 32.8 & 38.6 & 89.2 & 11.7 & 6.6 \\
\hline
\end{tabular}

When vulnerability for the species with the most area predicted SH under modern-day conditions-Artemisia tridentata, Gutierrezia sarothrae, Juniperus osteosperma, Achnatherum hymenoides, and Bouteloua gracilis - we see that these species are predicted to lose 44 to 54 percent of their modern-day SH in the 2050 time period and 54 to 67 percent by the 2100 time period. The three species with predicted modern-day SH of less than 1 percent-Tetradymia spinosa, Lupinus argenteus, and Pinus strobiformis - are predicted the lose 58 to 77 percent of their modern-day SH in the 2050 time period and 89 to 93 percent of their modern-day SH in the 2100 time period. 
Table 11. An illustrative subsection of summary data presented in appendix A, table 4 for the suitable habitat (SH) vulnerability and potential scores for a species. The vulnerability score represents the suitable habitat (SH) area, averaged over three climate scenarios, predicted to decrease in the future, divided by area predicted as SH for the species in modern-day. The higher the score, the more SH predicted to be lost and the higher the species' predicted vulnerability. The potential score is the $\mathrm{SH}$, averaged over three climate scenarios, predicted to be gained in the future divided by the area predicted as $\mathrm{SH}$ for the species in modern-day. The higher the potential score, the more SH is predicted to be gained during the future time period. A score greater than 1 indicates the species is predicted to have more $\mathrm{SH}$ in the future than was predicted for the modern day. PRISM climate data was used to predict modern-day SH and future climate scenarios were represented by IPPC scenarios B1 (global temperature rise of $2.4^{\circ} \mathrm{C}$ ), $\mathrm{A} 1 \mathrm{~B}$ (global temperature rise of $2.8^{\circ} \mathrm{C}$ ), and $\mathrm{A} 2$ (global temperature rise of $3.4^{\circ} \mathrm{C}$ ) for the time period 2050 (2040-2069) and 2100 (2070-2100).

\begin{tabular}{ccccc}
\hline & $\begin{array}{l}\text { Vulnerability } \\
\text { scores }\end{array}$ & \multicolumn{2}{l}{$\begin{array}{l}\text { Opportunity } \\
\text { scores }\end{array}$} \\
\hline time period & $\mathbf{2 0 5 0}$ & $\mathbf{2 1 0 0}$ & $\mathbf{2 0 5 0}$ & $\mathbf{2 1 0 0}$ \\
\hline \multicolumn{5}{c}{} \\
Trees & & & \\
\hline Pinus flexilis & -0.922 & -0.967 & 0.122 & 0.115 \\
\hline Yucca brevifolia & -0.691 & -0.894 & 0.846 & 0.748 \\
\hline Shrubs & & & & \\
\hline Artemisia tridentata & -0.486 & -0.59 & 0.095 & 0.067 \\
\hline Grasses & & & & \\
\hline Pleuraphis rigida & -0.837 & -0.969 & 0.644 & 0.406 \\
\hline
\end{tabular}

Species Potential to Gain Suitable Habitat

Species' potential scores ranged from 0.044 (least gain of suitable habitat) to 2.333 (most gain of suitable habitat) in the 2050 time period and from 0.006 to 4.019 in the 2100 time period (appendix A, table 4; illustrated table 11). Scores larger than 1.0 indicate that the species' gain of future SH area was predicted to be greater than the area of its predicted modern-day SH. For the 2050 time period, six tree species had scores greater than 1.0: Parkinsonia florida, Acer glabrum, Acer negundo Juniperus coahuilensis, Prosopis velutina, and Quercus havardii. In the 2100 time period, all of these trees, except Quercus havardii and with the addition of Prosopis glandulosa, had scores greater than 1.0. Ten shrub species were predicted to gain more SH than their modern-day SH for the 2050 time period:

Simmondsia chinensis, Atriplex obovata, Ziziphus obtusifolia, Atriplex filifolia, Ephedra torreyana, Ephedra trifurca, Fouquieria splendens, Lycium andersonii, Parthenium incanum, Shepherdia canadensis, and Suaeda moquinii. For the 2100 time period, all of the 2050 listed shrubs and Baccharis sarothroides, Eriogonum wrightii, Flourensia cernua, Larrea tridentata, and Paxistima myrsinites had potential scores greater than one. The grass species with the most predicted potential to gain $\mathrm{SH}$ for the 2050 time period were Dasyochloa pulchella, Muhlenbergia porteri, Elymus glaucus, and Pleauraphis mutica. For the 2100 time period, five grass species had predicted potential scores greater than 1.0: Boutleoua eriopoda, Dasyochloa pluchella, Hilaria belangeri, Koeleria macrantha, and Muhlenbergia porteri.

The lowest potential scores ( 0.25 and less) indicated those species that will gain no more than 25 percent of their modern-day SH in the future. For the trees this includes Abies concolor, Juniperus deppeana, Juniperus osteosperma, Picea engelmannii, Pinus flexilis, Pinus monophylla, Pinus 
ponderosa, and Pinus strobiformis for the 2050 time period. In the 2100 time period, the potential scores for Abies concolor, Juniperus deppeana, and Juniperus osetesperma were higher than 0.25 ; the other species remained in the low category with the addition of Abies lasiocarpa, Pinus contorta, and Populus tremuloides. Twenty-one shrubs had low potential scores in the 2050 time period; four of these had higher potential scores in the 2100 time period but, with the addition of other species with lower scores, there was a total of twenty-seven plant species in the low category in this time period. Eight grass species had low potential scores in both the 2050 and 2100 time periods: Achnatherum hymenoides, Achnatherum speciosum, Achnatherum thurberianum, Bouteloua gracilis, Elymus elymoides, Leymus cinereus, Poa secunda, and Schizachyrium scoparium,

\section{Relative Risk}

The risk analysis (tables 12,13, and 14) illustrates a complex interaction within the species between predicted vulnerability to loss of SH and potential to gain SH. Except for the two opposing ends of the categories - low vulnerability/high to very high potential of gain and very high vulnerability to loss SH/ low potential for gain SH where plant "winners" and plant "losers" can be predicted - the regional response of species can only be generally categorized by its relative potential to gain new SH and lose modern-day SH. 
Table 12. Assignment of tree species to risk categories. Risk categories consist of categorical rankings of a species' vulnerability and potential scores combined. Vulnerability is defined as the proportion of the area of suitable habitat $(\mathrm{SH})$ predicted to decrease in the 2050 time period averaged over three future climate change scenarios divided by the area predicted for the species as SH for modern-day climate conditions. Species that have are predicted to have 5 percent or more $\mathrm{SH}$ regionally in the modern day are indicated. Future climate scenarios were represented by IPPC scenarios B1 (global temperature rise of $2.4^{\circ} \mathrm{C}$ ), A1B (global temperature rise of $2.8^{\circ} \mathrm{C}$ ), and $\mathrm{A} 2$ (global temperature rise of $3.4^{\circ} \mathrm{C}$ ) for the time period 2050 (2040-2069) and 2100 (20702100).

\section{Potential}

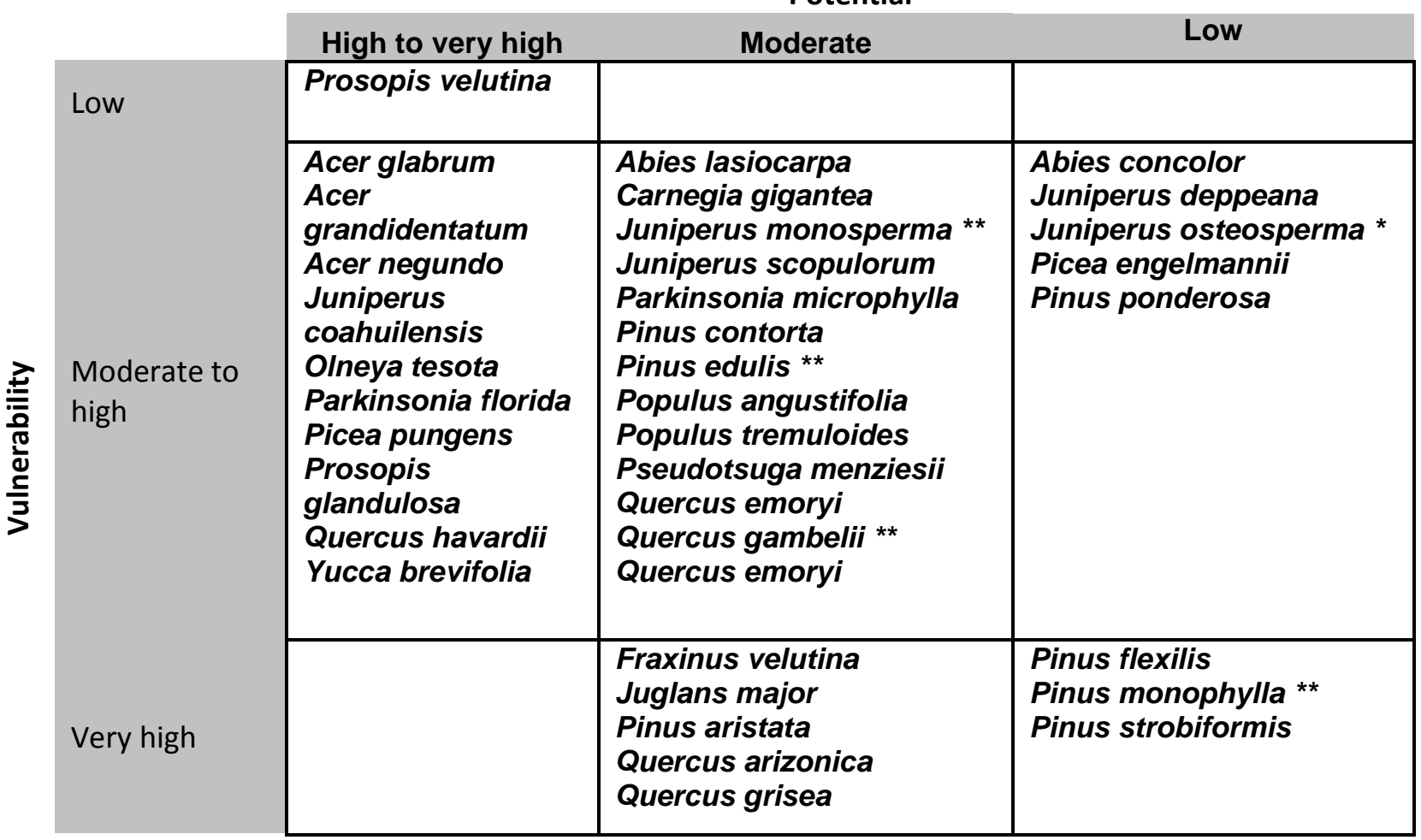

* Species is predicted to have SH in 20 percent of more of the study area under modern-day climate conditions

** Species is predicted to have SH in more than 10 percent and less than 20 percent of the study area under modern-day climate conditions 
Table 13. Assignment of shrub species to risk categories. Risk categories consist of categorical rankings of a species' vulnerability and potential scores combined. Vulnerability is defined as the proportion of the area of suitable habitat predicted to decrease in the 2050 time period averaged over three future climate change scenarios divided by the area predicted for the species as suitable habitat for modern-day climate conditions. Future climate scenarios were represented by IPPC scenarios B1 (global temperature rise of $2.4^{\circ} \mathrm{C}$ ), A1B (global temperature rise of $2.8^{\circ} \mathrm{C}$ ), and $\mathrm{A} 2$ (global temperature rise of $3.4^{\circ} \mathrm{C}$ ) for the time period 2050 (2040-2069) and 2100 (20702100).

\begin{tabular}{|c|c|c|c|}
\hline & \multicolumn{3}{|c|}{ Potential } \\
\hline & High to very high & Moderate & Low \\
\hline Low & Shepherdia canadensis & & \\
\hline Moderate to high & $\begin{array}{l}\text { Arctostaphylos uva-ursi } \\
\text { Artemisia filifolia } \\
\text { Atriplex obovata } \\
\text { Coleogyne ramosissima } \\
\text { Ephedra torreyana } \\
\text { Ephedra trifurca } \\
\text { Fouquieria splendens } \\
\text { Larrea tridentata ** } \\
\text { Parthenium incanum } \\
\text { Salix geyeriana } \\
\text { Simmondsia chinensis } \\
\text { Suaeda moquinii } \\
\text { Symphoricarpos } \\
\text { rotundifolius } \\
\text { Yucca elata } \\
\text { Ziziphus obtusifolia }\end{array}$ & $\begin{array}{l}\text { Acacia constricta } \\
\text { Acacia gregii } \\
\text { Ambrosia dumosa } \\
\text { Amelanchier alnifolia } \\
\text { Amelanchier utahensis } \\
\text { Arctostaphylos } \\
\text { pungens } \\
\text { Artemisia bigelovii } \\
\text { Artemisia frigida } \\
\text { Artemisia nova ** } \\
\text { Atriplex canescens ** } \\
\text { Atriplex confertifolia ** } \\
\text { Artemisia tridentata * } \\
\text { Atriplex gardneri } \\
\text { Atriplex polycarpa } \\
\text { Baccharis sarothroides } \\
\text { Cercocarpus montanus } \\
\text { Ephedra nevadensis } \\
\text { Encelia viridis ** } \\
\text { Eriogonum wrightii } \\
\text { Fallugia paradoxa } \\
\text { Grayia spinosa } \\
\text { Gutierrezia } \\
\text { microcephala } \\
\text { Gutierrezia sarothrae * } \\
\text { Juniperus communis } \\
\text { Krascheninnikovia } \\
\text { lanata ** } \\
\text { Lupinus argenteus } \\
\text { Mahonia repens } \\
\text { Mimosa aculeaticarpa } \\
\text { Opuntia engelmannii } \\
\text { Paxistima myrsinites } \\
\text { Prunus virginiana } \\
\text { Purshia mexicana }\end{array}$ & $\begin{array}{l}\text { Chrysothamnus } \\
\text { viscidiflorus ** } \\
\text { Robinia neomexicana } \\
\text { Symphoricarpos } \\
\text { oreophilus } \\
\text { Yucca baccata } \\
\text { Yucca glauca }\end{array}$ \\
\hline
\end{tabular}




\begin{tabular}{|c|c|c|c|}
\hline & \multicolumn{3}{|c|}{ Potential } \\
\hline & High to very high & Moderate & Low \\
\hline & & $\begin{array}{l}\text { Purshia tridentata ** } \\
\text { Quercus turbinella } \\
\text { Rhus trilobata } \\
\text { Ribes cereum } \\
\text { Ribes montigenum } \\
\text { Sarcobatus } \\
\text { vermiculatus ** } \\
\text { Symphoricarpos albus } \\
\text { Tetradymia spinosa } \\
\text { Vaccinium myrtillus } \\
\text { Vaccinium scoparium } \\
\text { Yucca angustissima } \\
\text { Yucca baccata } \\
\text { Yucca elata }\end{array}$ & \\
\hline Very high & Lycium andersonii & $\begin{array}{l}\text { Ambrosia deltoidea } \\
\text { Arctostaphylos patula } \\
\text { Arctostaphylos pringlei } \\
\text { Atriplex corrugata } \\
\text { Canotia holacantha } \\
\text { Chrysothamnus } \\
\text { depressus } \\
\text { Chrysothamnus greenei } \\
\text { Ericameria linearifolia } \\
\text { Flourensia cernua } \\
\text { Garrya wrightii } \\
\text { Hymenoclea salsola } \\
\text { Menodora spinescens } \\
\text { Opuntia basilaris } \\
\text { Purshia stansburiana } \\
\text { Rhus microphylla } \\
\text { Rosa woodsii } \\
\text { Salazaria mexicana } \\
\text { Tetradymia glabrata }\end{array}$ & $\begin{array}{l}\text { Artemisia arbuscula } \\
\text { Atriplex hymenelytra } \\
\text { Ceanothus greggii } \\
\text { Cercocarpus intricatus } \\
\text { Cercocarpus ledifolius } \\
\text { Encelia farinosa } \\
\text { Ericameria nauseosa } \\
\text { Eriogonum fasciculatum } \\
\text { Garrya flavescens } \\
\text { Lycium pallidum } \\
\text { Picrothamnus desertorum } \\
\text { Prunus fasciculata } \\
\text { Rhus ovata } \\
\text { Yucca schidigera }\end{array}$ \\
\hline
\end{tabular}

* Species is predicted to have SH in 20 percent of more of the study area under modern-day climate conditions

** Species is predicted to have SH in more than 10 percent and less than 20 percent of the study area under modernday climate conditions 
Table 14. Assignment of grass species to risk categories. Risk categories consist of categorical rankings of a species' vulnerability and potential scores combined. Vulnerability is defined as the proportion of the area of suitable habitat (SH) predicted to decrease in the 2050 time period averaged over three future climate change scenarios divided by the area predicted for the species as $\mathrm{SH}$ for modern-day climate conditions. Future climate scenarios were represented by IPPC scenarios B1 (global temperature rise of $2.4^{\circ} \mathrm{C}$ ), A1B (global temperature rise of $2.8^{\circ} \mathrm{C}$ ), and $\mathrm{A} 2$ (global temperature rise of $3.4^{\circ} \mathrm{C}$ ) for the time period 2050 (2040-2069) and 2100 (20702100).

\begin{tabular}{|c|c|c|c|}
\hline & \multicolumn{3}{|c|}{ Potential } \\
\hline & High to very high & Moderate & Low \\
\hline \multicolumn{4}{|l|}{ Low } \\
\hline $\begin{array}{r}\text { Moderate } \\
\text { to high }\end{array}$ & $\begin{array}{l}\text { Dasyochloa } \\
\text { pulchella } \\
\text { Elymus glaucus } \\
\text { Muhlenbergia } \\
\text { porteri } \\
\text { Hordeum jubatum }\end{array}$ & $\begin{array}{l}\text { Bouteloua curtipendula } \\
\text { Bouteloua hirsuta } \\
\text { Festuca brachyphylla } \\
\text { Festuca idahoensis } \\
\text { Festua thurberi } \\
\text { Hesperostipa comata ** } \\
\text { Muhlenbergia emersleyi } \\
\text { Pascopyrum smithii } \\
\text { Pleuraphis jamesii ** } \\
\text { Muhlenbergia montana } \\
\text { Poa fendleriana }\end{array}$ & $\begin{array}{l}\text { Achnatherum } \\
\text { hymenoides * } \\
\text { Bouteloua eriopoda } \\
\text { Bouteloua gracilis * } \\
\text { Elymus elymoides ** } \\
\text { Hilaria belangeri } \\
\text { Koeleria macrantha } \\
\text { Leymus cinereus } \\
\text { Poa secunda ** } \\
\text { Sporobolus airoides }\end{array}$ \\
\hline Very high & $\begin{array}{l}\text { Pleuraphis mutica } \\
\text { Sporobolus } \\
\text { flexuosus }\end{array}$ & $\begin{array}{l}\text { Festuca arizonica } \\
\text { Pleuraphis rigida } \\
\text { Sporobolus cryptandrus ** } \\
\text { Elymus trachycaulus }\end{array}$ & $\begin{array}{l}\text { Achnatherum speciosum } \\
\text { Achnatherum } \\
\text { thurberianum } \\
\text { Schizachyrium scoparium }\end{array}$ \\
\hline
\end{tabular}

* $\quad$ Species is predicted to have SH in 20 percent of more of the study area under modern-day climate conditions

** Species is predicted to have SH in more than 10 percent and less than 20 percent of the study area under modernday climate conditions 


\section{Summary and Discussion}

This study examines the potential response of 166 plant species to predicted climate change from the perspective of two time periods and three different potential emission scenarios. Predicted future habitat predictions were classified as decreasing, maintaining, or increasing suitability. Using these categories, we evaluated the concurrence among the different model results and calculated metrics indicating potential vulnerability, potential, and risk for each species using the average of the three emission scenarios for each time period.

Concurrence among the models showed that predictions for areas of decreasing suitability were much higher than predictions for maintained or decreased suitability. This indicates that the predictions of maintenance of suitable habitat or potential new suitable habitats are highly dependent upon the actual climate change trajectory that is used for predictions.

Suitable habitat is an indicator of the amount of actual habitat that is available for a plant species, but it does not reflect the actual occupancy of the species within that suitable habitat. In this study SH does not take into account the myriad biotic and abiotic interactions and conditions that influence the realized niche-space of a species within the SH. As an indicator, it is useful for determining a broad picture assessment of species occurrence and the potential impacts that could occur as a result of climate variation. The study makes no claims about the species' ability to adapt in situ to loss of SH or the species' ability to occupy potential SH.

In the first part of the study, vulnerability was defined as the proportion of modern-day SH that would be lost in each time period averaged over the three climate models. All 166 species were predicted to lose modern-day SH in the future climate change scenarios. In the 2050 time period, only two species were predicted to lose less than 25 percent of their modern-day SH and 49, or nearly 30 percent of the 166 species, were predicted to lose 75 percent or more of their modern-day suitable habitat. For the 2100 time period, only one species was predicted to lose less than 25 percent of its modern-day SH and nearly half, 88 of 166 species, were predicted to lose 75 percent or more of their modern-day SH.

The second part of the study examined the potential for a species to adapt as measured by the amount of new SH that might be gained in each time period averaged over the three climate models. The model results indicated that some species will have potential to occupy double or more of their modern-day habitat in the future; this includes 21 species in the 2050 time period and 28 in the 2100 time period. Other species will have very little potential to occupy new SH in the future; based on a threshold of 25 percent or less of potential SH, this includes 30 species in the 2050 time period and 34 species in the 2100 time period.

The third part of the study was a relative risk assessment, done only for the 2050 time period averaged over the three climate models. In this assessment, nine risk categories were used to classify the proportion of a species' vulnerability score to its potential score. The risk analysis showed that there are plants that are likely to be overall winners, others overall losers, and others for which losses and gains might be distributed across the region. Overall winners were predicted to be Prosopis velutina and Shepherdia canadensis. Overall losers included three tree species (Pinus flexilis, P. monophylla, and $P$. strobiformis), 14 shrub species (Artemisia arbuscula, Atriplex hymenelytra, Ceanothus greggii, Cercocarpus intricatus, Cercocarpus ledifolius, Encelia farinosa, Ericameria nauseosa, Eriogonum fasciculatum, Garry flavescnes, Lycium pallidum, Picrothamnus desertorum, Prunus faciculata, Rhus ovata, and Yucca schidigera), and three grass species (Achnatherum speciosum Achnatherum thurberianum, Schizachyrium scoparium). 


\section{Factors in Interpreting Results}

A model is only an approximation of expected conditions. The map output and derived metrics presented in this study indicate possible trends in the future. Their interpretation and use should be done with mindfulness of the various limitations inherently involved in developing the models and the other factors that ultimately influence a species' distribution. While we found our model output to be consistent, based on the high AUC metrics obtained, there are other points of consideration.

The initial model output is influenced by the quality of input data and the decisions made in calibrating the model runs. In this study the key input factors are the occurrence data and the climate data, both current and future climate change models. Corrections for bias in sample data (occurrence data) have been a topic of recent discussion within the Maxent modeling community (Phillips and others, 2009). Newer versions of Maxent than the one used in this study provide some correction approaches for occurrence data that were collected in a non-systematic manner. Although these approaches were not applied to the occurrence data in this study, typically these concerns are related to the non-systematic sampling bias associated with occurrence data derived from herbaria and museum records (Phillips and others, 2009). In this study, the collective set of studies and their associated sites constitute a broad representation of the study area and its associated environments. Additional filters were applied to eliminate species that may have been underrepresented due to the nature of the field studies used. Although a threshold of 50 or more occurrence records was used as an additional filter, some of the species with low numbers of occurrence records may be underrepresented. For example, Rhus ovata, with only 50 locations, often occurs in narrowly defined locations and the available location data may cause underestimation of its $\mathrm{SH}$ range.

There are a number of climate models available for future climate modeling. Virtually all of these derive from models reported in AR4. There is no definitive model of future climate change, because the science of climate modeling is constantly being refined and the drivers of climate change are dynamic and not stable, particularly with respect to human contribution to greenhouse gasses. The ongoing 5th IPPC plans to produce a new set of climate models in their 2014 reporting. Rather than choose one climate model thought to be best fitting to previous Southwest regional climate, for this project we chose to look at potential response framed by climate models representing lower projected climate change and models representing higher projected climate change. Users of these data should benefit by having the predictions of the responses of Southwest plant species to climate change based on different views of how climate might change in the future. This approach facilitates comparison and evaluation of the convergence or non-convergence of predicted species response across a range of possible climate change trajectories. Owing to the fact that climate change is not fully predictable, this view provides more information than that based on a single trajectory.

One feature of the ClimateWizard climate models to note is that these climate models have been statistically downscaled to $12-\mathrm{km}$ resolution from global climate models that were developed at 2.5- to 3.5-degree resolution. Temperature and precipitation are generally considered to be good proxies to topography in most cases; however, at the resolution of $12 \mathrm{~km}$, the user should remember that topographic variation is averaged and microsite variation is not captured within each grid cell of model results. This means that there may be micro-scale sites of SH suitability or unsuitability that were not captured with each grid cell of model results. The current distribution models were run at the standard

grid cell size of $843.5 \mathrm{~m}^{2}$, which corresponded to the available modern-day climate data. The future projections, although displayed at the standard grid cell size, have less resolution because of the 12-km resolution of the future climate models. For this reason decision-making should not be based on single grid cell results. 
Maxent may be conservative in its interpolation and predict more tightly to the species' occurrence input locations than other modeling approaches. The choice of threshold breakpoint becomes important in how any conservative bias is expressed in the $\mathrm{SH}$ predictions. A different threshold approach would have set the breakpoint lower in order to capture all possible suitable habitats, even if occupation frequency were very low.

The choice of threshold is a good indicator of the type of error that may occur in the model results. For the modern-day and future suitable habitat results, the chosen threshold reduces the probability of false positive predictions. In other words, there is less chance of a prediction of SH in areas not actually SH. However, for the potential SH, the opposite situation occurs where there is more chance of false negatives where potential SH exists but was not predicted. As noted by Freeman and Moisen (2008) and Franklin (2009), the continuous model output provides the unconstrained prediction and this output can be used to develop different views of predicted $\mathrm{SH}$.

It is important to note that a number of ecological and physiological factors are not included in this first-order assessment but that ultimately influence how a species responds to climate change. Within modern predicted SH, the actual distribution of a species will depend on factors such as edaphic and micro-topographic factors, biological interactions including mutualisms and predation, and various disturbance factors. These factors will also be of importance in the species' future occupation of any SH. In addition a species' ability to physiologically adapt to changing conditions, such as through changing phenology, can mitigate changes in habitat suitability. The ability of a species to occupy potential habitat is very dependent upon a species' ability to migrate to the new areas. Migration is a function of the species' dispersal characteristics, the establishment environment in the new habitat, and landscape features such as fragmentation and transport corridors. The authors acknowledge the importance of these factors and, for this reason, have labeled potential new SH as only potential.

\section{Next Steps}

A major goal of this study was to develop model outputs that could be used to support more focused study of how climate change may affect plant species and vegetation distribution in the Southwest. The approach can be applied in other broad biomes with the use of an appropriate subset of modern-day PRISM data, ClimateWizard climate scenarios, and plant species presence data. Also, the approach can be applied iteratively to the Southwest as finer resolution and/or more refined climate scenarios are developed.

The purpose of this report was to present the methods, model outputs, and a first-order assessment for these 166 plant species. This report provides information that natural resource managers can use as input to more comprehensive climate change action planning, such as contemporary largearea planning documents (for example Bureau of Land Management Resource Management Plans) that could help prioritize actions for a future environment. There are a number of follow-on studies that can be pursued within the region using these data and results:

- Assessment of individual species vulnerability using a broader set of criteria,

- Evaluation of model results against long-term plot data existing within the region,

- Assessment of predicted species change within ecoregions, by major vegetation types and/or by administrative unit, or

- Identification of landscapes at risk due to loss of species and landscapes of interest due to potential for gain of species.

The products and findings of this report provide one perspective that might inform management decisions to be considered and focused studies to be conducted in the face of rapidly changing climate. Ultimately, these predictions can serve as the basis for specific hypotheses of species, vegetation, and 
landscape change. The report also presents an analytic approach toward assessing species response to changing climate that might be duplicated and refined in other regions in the nation.

\section{Acknowledgments}

This research was funded by the U.S. Geological Survey Global Change Program and the Southwest Biological Science Center. The authors thank Joel Michaelsen (University of California Santa Barbara, Santa Barbara, Calif.), Marissa Howell (Northern Arizona University, Flagstaff, Ariz.), and Terry Arundel (U.S. Geological Survey, Flagstaff, Ariz.), who provided support for early phases of the study and to all providers of species plot data.

\section{References Cited}

Bailey, Robert G., 1995, Description of the ecoregions of the United States (2d ed., revised and expanded): U.S. Department of Agriculture, Forest Service Miscellaneous Publication 1391, 108 p., available at http://www.fs.fed.us/land/ecosysmgmt/ecoreg1_home.html.

Climate Wizard, 2009, Future Climate Model: accessed during 2009, at http://www.climatewizard.org/.

Cole, K.L., Ironside, K.E., Arundel, S.T., Duffy, P.B., and Shaw, John, 2007, Modeling future plant distributions on the Colorado Plateau-An example using Pinus edulis, in van Riper III, Charles, and Sogge, M.K., eds., The Colorado Plateau III-Integrating research and resources management for effective conservation: Tucson, The University of Arizona Press, p. 319-330.

Cole, K.L., Ironside, K.E., Eischeid, Jon, Garfin, Greg, Duffy, P.B., and Toney, Chris, 2011, Past and ongoing shifts in Joshua tree distribution support future modeled range contraction: Ecological Applications, v. 21, no. 1, p. 137-149.

Elith, Jane, Graham, C.H., Anderson, R.P., and 24 others, 2006, Novel methods improve prediction of species' distributions from occurrence data: Ecography, v. 29, no. 2, p. 129-151.

Elith, Jane, Phillips, S.J., Hastie, Trevor, Dudik, Miroslav, Chee, Y.E., and Yates, C.J., 2011, A statistical explanation of MaxEnt for ecologists: Diversity and Distributions, v. 17, no. 1, p. 4357.

Ernst, A.E., Schrader, Scott, Lopez, Veronica, and 8 others, 2007, Land Stewardship. Chapter 4. in Prior-Magee, J.S., Boykin, K.G., Bradford, D.F., and 5 others, eds., Southwest Regional Gap Analysis Project final report: U.S. Geological Survey, Gap Analysis Program, Moscow, ID., available at http://fws-nmcfwru.nmsu.edu/swregap/report/SWReGAP\%20Final\%20Report.pdf.

Franklin, Janet, 2009, Mapping species distributions - Spatial inference and prediction: Cambridge, U.K., Cambridge University Press, 320 p.

Freeman, E.A., and Moisen, G.C., 2008, A comparison of the performance of threshold criteria for binary classification in terms of predicted prevalence: Ecological Modeling, v. 217, p. 48-58.

Integrated Taxonomic Information System, accessed 2010 at http://www.itis.gov/.

Liu, C.R., Berry, P.M., Dawson, T.P., and Pearson, R.G., 2005, Selecting thresholds of occurrence in the prediction of species distributions: Ecography, v. 28, p. 385-393.

NatureServe Explorer, 2010, Ecological communities and Systems: database accessed 2010 at http://www.natureserve.org/explorer/servlet/NatureServe?init=Ecol.

Overpeck, Jonathan, and Udall, Bradley, 2010, Dry times ahead: Science, v. 328, no. 5986, p. 16421643.

PRISM Climate Group, 2004, Oregon State University, 30-arcsec (800m) Normals, accessed 2009 at http://www.prismclimate.org.

Phillips, S.J., Anderson, R.P., and Schapire, R.E., 2006, Maximum entropy modeling of species' geographic distribution: Ecological Modeling, v. 190, no. 3-4, p. 231-259. 
Phillips, S.J., Dudik, Miroslav, Elith, Jane, and 4 others, 2009, Sample selection bias and presence-only distribution models - Implications for background and pseudo-absence data: Ecological Applications, v. 19, no. 1, p. 181-197.

Santika, Truly, 2011, Assessing the effect of prevalence on the predictive performance of species distribution models using simulated data: Global Ecology and Biogeography, v. 20, no. 1, p. 181-192.

Seager, Richard, Ting, Mingfang, Held, Isaac, and 10 others, 2007, Model projections of an imminent transition to a more arid climate in Southwestern North America: Science, v. 316, no. 5828, p. 1181-1184.

Shafer, S.L., Bartlein, P.J., and Thompson, R.S., 2001, Potential changes in the distributions of western North America tree and shrub taxa under future climate scenarios: Ecosystems, v. 4, no. 3, p. 200-215.

Solomon, Susan, Qin, Dahe, Manning, Martin, and 5 others, eds., 2007, Climate change 2007-The physical science basis - Contribution of Working Group I to the Fourth Assessment Report of the Intergovernmental Panel on Climate Change: Cambridge, U.K., Cambridge University Press, $996 \mathrm{p}$.

Swets, John A., 1988, Measuring the accuracy of diagnostic systems: Science, v. 240, no. 4857, p. 1285-1293. 


\section{Contents of the Appendixes}

\section{Appendix A Assessment results for the 166 plant species: Summary tables}

Table 1. Plant species $(n=166)$ included in this study, number of locations for each species used to develop predicted modern-day and future climate change scenario models, and model performance metrics.

Table 2. Suitable habitat predictions for the study plant species $(n=166)$ showing the predicted modern-day proportion of the study area (S) and the percent of the modernday suitable habitat (SH) predicted in the future to be decreasing suitability (DS), increasing suitability (IS), and maintained suitability (MS).

Table 3. Model agreement for future suitable habitat $(\mathrm{SH})$ predictions for the study plant species $(n=166)$.

Table 4. Suitable habitat (SH) vulnerability and potential scores for each of the study plant species $(n=166)$ for two time periods.

\section{Appendix B Assessment results for the 166 plant species: Spatial models}

Link to Appendix B, Assessment Results for the 166 Plant Species: Spatial Models

Figures 1 to 166. The data are presented as a single large PDF; as one PDF each for trees, shrubs, and grasses; and as a set of 166 single-page PDFs - one for each of the species (2.6 GB total).

\section{Trees}

Abies concolor

Abies lasiocarpa

Acer glabrum

Acer grandidentatum

Acer negundo

Carnegiea gigantea

Fraxinus velutina

Juglans major

Juniperus coahuilensis

Juniperus deppeana

Juniperus monosperma

Juniperus osteosperma

Juniperus scopulorum

Olneya tesota

Parkinsonia florida

Parkinsonia microphylla

Picea engelmannii

Picea pungens

Pinus aristata 
Pinus contorta

Pinus edulis

Pinus flexilis

Pinus monophylla

Pinus ponderosa

Pinus strobiformis

Populus angustifolia

Populus tremuloides

Prosopis glandulosa

Prosopis velutina

Pseudotsuga menziesii

Quercus arizonica

Quercus emoryi

Quercus gambelii

Quercus grisea

Quercus havardii

Yucca brevifolia

\section{Shrubs}

Acacia constricta

Acacia greggii

Ambrosia deltoidea

Ambrosia dumosa

Amelanchier alnifolia

Amelanchier utahensis

Arctostaphylos patula

Arctostaphylos pringlei

Arctostaphylos pungens

Arctostaphylos uva-ursi

Artemisia arbuscula

Artemisia bigelovii

Artemisia filifolia

Artemisia frigida

Artemisia nova

Artemisia tridentata

Atriplex canescens

Atriplex confertifolia

Atriplex corrugata

Atriplex gardneri

Atriplex hymenelytra

Atriplex obovata

Atriplex polycarpa

Baccharis sarothroides

Canotia holacantha

Ceanothus greggii

Cercocarpus intricatus

Cercocarpus ledifolius 
Cercocarpus montanus

Chrysothamnus depressus

Chrysothamnus greenei

Chrysothamnus viscidiflorus

Coleogyne ramosissima

Encelia farinosa

Ephedra nevadensis

Ephedra torreyana

Ephedra trifurca

Ephedra viridis

Ericameria linearifolia

Ericameria nauseosa

Eriogonum fasciculatum

Eriogonum wrightii

Fallugia paradoxa

Flourensia cernua

Fouquieria splendens

Garrya flavescens

Garrya wrightii

Grayia spinosa

Gutierrezia microcephala

Gutierrezia sarothrae

Hymenoclea salsola

Juniperus communis

Krascheninnikovia lanata

Larrea tridentata

Lupinus argenteus

Lycium andersonii

Lycium pallidum

Mahonia repens

Menodora spinescens

Mimosa aculeaticarpa

Opuntia basilaris

Opuntia engelmannii

Parthenium incanum

Paxistima myrsinites

Picrothamnus desertorum

Prunus fasciculata

Prunus virginiana

Purshia mexicana

Purshia stansburiana

Purshia tridentata

Quercus turbinella

Rhus microphylla

Rhus ovata

Rhus trilobata 
Ribes cereum

Ribes montigenum

Robinia neomexicana

Rosa woodsii

Salazaria mexicana

Salix geyeriana

Sarcobatus vermiculatus

Shepherdia canadensis

Simmondsia chinensis

Suaeda moquinii

Symphoricarpos albus

Symphoricarpos oreophilus

Symphoricarpos rotundifolius

Tetradymia glabrata

Tetradymia spinosa

Vaccinium myrtillus

Vaccinium scoparium

Yucca angustissima

Yucca baccata

Yucca elata

Yucca glauca

Yucca schidigera

Ziziphus obtusifolia

\section{Grasses}

Achnatherum hymenoides

Achnatherum speciosum

Achnatherum thurberianum

Bouteloua curtipendula

Bouteloua eriopoda

Bouteloua gracilis

Bouteloua hirsuta

Dasyochloa pulchella

Elymus elymoides

Elymus glaucus

Elymus trachycaulus

Festuca arizonica

Festuca brachyphylla

Festuca idahoensis

Festuca thurberi

Hesperostipa comata

Hilaria belangeri

Hordeum jubatum

Koeleria macrantha

Leymus cinereus

Muhlenbergia emersleyi

Muhlenbergia montana 


\author{
Muhlenbergia porteri \\ Pascopyrum smithii \\ Pleuraphis jamesii \\ Pleuraphis mutica \\ Pleuraphis rigida \\ Poa fendleriana \\ Poa secunda \\ Schizachyrium scoparium \\ Sporobolus airoides \\ Sporobolus cryptandrus \\ Sporobolus flexuosus
}




\section{Appendix A Assessment Results for the 166 Plant Species: Summary Tables}

Table 1. Plant species $(n=166)$ included in this study, number of locations for each species used to develop predicted modern-day and future climate change scenario models, and model performance metrics. AUC indicates the receiver operator curve area under curve statistic. The sample data was randomly divided into a test data set containing 20 percent of the data (AUC20) and a training dataset with the remaining 80 percent (AUC20 training). All sample data was incorporated in the second model run (AUC all training). The overall threshold accuracy score indicates the number of species' standard locations correctly predicted as suitable using the 50 percent threshold criterion divided by the total number of standard locations for the species. 


\begin{tabular}{|c|c|c|c|c|c|c|c|}
\hline Species & 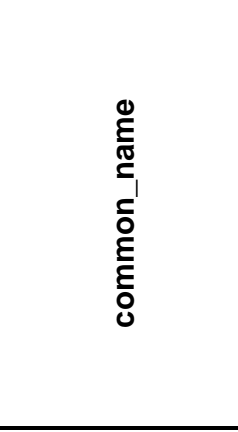 & 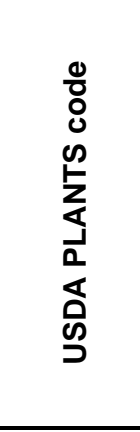 & 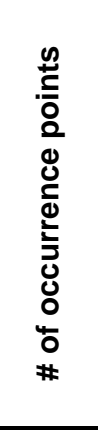 & 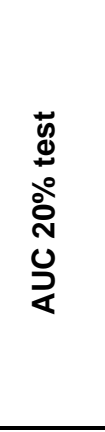 & 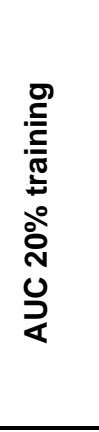 & 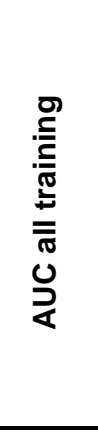 & 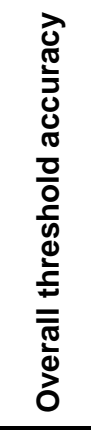 \\
\hline \multicolumn{8}{|l|}{ Trees } \\
\hline Abies concolor & white fir & $\mathrm{ABCO}$ & 632 & 0.972 & 0.979 & 0.978 & 0.877 \\
\hline Abies lasiocarpa & subalpine fir & ABLA & 731 & 0.981 & 0.984 & 0.984 & 0.88 \\
\hline Acer glabrum & $\begin{array}{l}\text { Rocky } \\
\text { Mountain } \\
\text { maple }\end{array}$ & ACGL & 55 & 0.97 & 0.972 & 0.976 & 0.764 \\
\hline Acer grandidentatum & Bigtooth maple & ACGR3 & 123 & 0.989 & 0.995 & 0.995 & 0.911 \\
\hline Acer negundo & boxelder & ACNE2 & 122 & 0.944 & 0.99 & 0.987 & 0.902 \\
\hline Carnegiea gigantea & saguaro & CAGI10 & 539 & 0.987 & 0.99 & 0.99 & 0.911 \\
\hline Fraxinus velutina & velvet ash & FRVE2 & 59 & 0.949 & 0.989 & 0.987 & 0.814 \\
\hline Juglans major & $\begin{array}{l}\text { New Mexico } \\
\text { walnut }\end{array}$ & JUMA & 105 & 0.971 & 0.993 & 0.993 & 0.867 \\
\hline Juniperus coahuilensis & $\begin{array}{l}\begin{array}{l}\text { redberry } \\
\text { juniper }\end{array} \\
\end{array}$ & $\begin{array}{l}\text { JUCO1 } \\
1\end{array}$ & 137 & 0.994 & 0.998 & 0.998 & 0.942 \\
\hline Juniperus deppeana & alligator juniper & JUDE2 & 1259 & 0.98 & 0.984 & 0.984 & 0.902 \\
\hline Juniperus monosperma & $\begin{array}{l}\text { oneseed } \\
\text { juniper }\end{array}$ & JUMO & 1560 & 0.907 & 0.923 & 0.922 & 0.82 \\
\hline Juniperus osteosperma & Utah juniper & JUOS & 5550 & 0.886 & 0.888 & 0.887 & 0.84 \\
\hline Juniperus scopulorum & $\begin{array}{l}\text { Rocky } \\
\text { mountain } \\
\text { juniper }\end{array}$ & JUSC2 & 759 & 0.926 & 0.956 & 0.954 & 0.837 \\
\hline Olneya tesota & ironwood & OLTE & 317 & 0.994 & 0.995 & 0.995 & 0.921 \\
\hline Parkinsonia florida & blue paloverde & PAFL6 & 175 & 0.987 & 0.992 & 0.992 & 0.931 \\
\hline Parkinsonia microphylla & $\begin{array}{l}\text { littleleaf palo } \\
\text { verde }\end{array}$ & PAMI5 & 639 & 0.986 & 0.99 & 0.99 & 0.911 \\
\hline Picea engelmannii & $\begin{array}{l}\text { Engelmann } \\
\text { spruce }\end{array}$ & PIEN & 959 & 0.975 & 0.981 & 0.98 & 0.882 \\
\hline Picea pungens & blue spruce & PIPU & 235 & 0.976 & 0.988 & 0.988 & 0.868 \\
\hline Pinus aristata & $\begin{array}{l}\text { bristlecone } \\
\text { pine }\end{array}$ & PIAR & 64 & 0.988 & 0.997 & 0.997 & 0.906 \\
\hline Pinus contorta & lodgepole pine & $\mathrm{PICO}$ & 344 & 0.98 & 0.992 & 0.991 & 0.927 \\
\hline Pinus edulis & $\begin{array}{l}\text { Colorado } \\
\text { pinyon }\end{array}$ & PIED & 3827 & 0.91 & 0.919 & 0.917 & 0.852 \\
\hline Pinus flexilis & limber pine & PIFL2 & 255 & 0.957 & 0.986 & 0.985 & 0.894 \\
\hline Pinus monophylla & $\begin{array}{l}\text { single-leaf } \\
\text { juniper }\end{array}$ & PIMO & 1765 & 0.948 & 0.96 & 0.959 & 0.901 \\
\hline Pinus ponderosa & $\begin{array}{l}\begin{array}{l}\text { ponderosa } \\
\text { pine }\end{array} \\
\end{array}$ & $\mathrm{PIPO}$ & 3920 & 0.966 & 0.968 & 0.968 & 0.916 \\
\hline Pinus strobiformis & $\begin{array}{l}\text { southwestern } \\
\text { white pine }\end{array}$ & PIST3 & 139 & 0.998 & 0.999 & 0.999 & 0.971 \\
\hline Populus angustifolia & $\begin{array}{l}\text { narrowleaf } \\
\text { cottonwood }\end{array}$ & POAN3 & 210 & 0.864 & 0.949 & 0.939 & 0.79 \\
\hline Populus tremuloides & quaking aspen & POTR5 & 2020 & 0.96 & 0.96 & 0.96 & 0.868 \\
\hline
\end{tabular}




\begin{tabular}{|c|c|c|c|c|c|c|c|}
\hline Species & 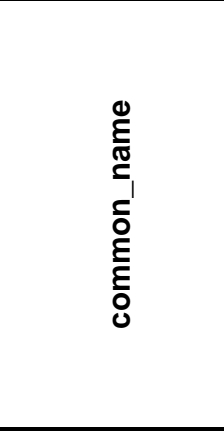 & 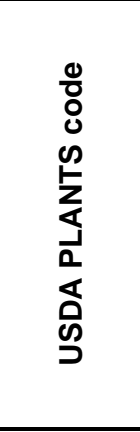 & 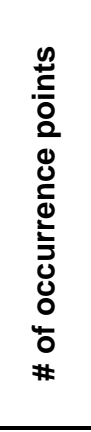 & 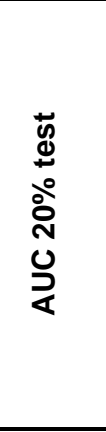 & 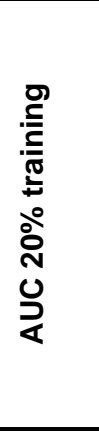 & 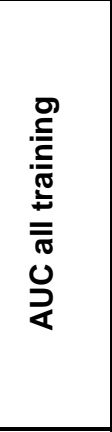 & 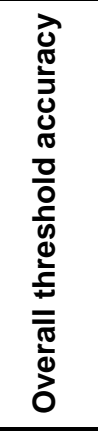 \\
\hline Prosopis glandulosa & $\begin{array}{l}\text { honey } \\
\text { mesquite }\end{array}$ & PRGL2 & 1180 & 0.956 & 0.962 & 0.961 & 0.88 \\
\hline Prosopis velutina & $\begin{array}{l}\text { velvet } \\
\text { mesquite }\end{array}$ & PRVE & 621 & 0.972 & 0.98 & 0.979 & 0.876 \\
\hline Pseudotsuga menziesii & douglas fir & PSME & 1522 & 0.959 & 0.964 & 0.964 & 0.855 \\
\hline Quercus arizonica & $\begin{array}{l}\text { Arizona white } \\
\text { oak }\end{array}$ & QUAR & 133 & 0.995 & 0.998 & 0.997 & 0.917 \\
\hline Quercus emoryi & emory oak & QUEM & 289 & 0.993 & 0.995 & 0.995 & 0.952 \\
\hline Quercus gambelii & Gambel's oak & QUGA & 2948 & 0.949 & 0.956 & 0.956 & 0.88 \\
\hline Quercus grisea & gray oak & QUGR3 & 301 & 0.982 & 0.992 & 0.991 & 0.877 \\
\hline Quercus havardii & $\begin{array}{l}\text { shinnery oak } \\
\text { (Havard) }\end{array}$ & QUHA3 & 86 & 0.982 & 0.986 & 0.995 & 0.965 \\
\hline Yucca brevifolia & Joshua tree & YUBR & 470 & 0.977 & 0.989 & 0.988 & 0.913 \\
\hline \multicolumn{8}{|l|}{ Shrubs } \\
\hline Acacia constricta & $\begin{array}{l}\text { twinthorn } \\
\text { acacia (white) }\end{array}$ & $\mathrm{ACCO} 2$ & 247 & 0.975 & 0.986 & 0.985 & 0.87 \\
\hline Acacia greggii & catclaw acacia & ACGR & 684 & 0.968 & 0.981 & 0.979 & 0.858 \\
\hline Ambrosia deltoidea & $\begin{array}{l}\text { triangle } \\
\text { bursage } \\
\end{array}$ & AMDE4 & 244 & 0.989 & 0.995 & 0.995 & 0.914 \\
\hline Ambrosia dumosa & white bursage & AMDU2 & 1970 & 0.974 & 0.976 & 0.976 & 0.916 \\
\hline Amelanchier alnifolia & $\begin{array}{l}\text { Saskatoon } \\
\text { serviceberry }\end{array}$ & AMAL2 & 499 & 0.966 & 0.978 & 0.977 & 0.852 \\
\hline Amelanchier utahensis & $\begin{array}{l}\text { Utah } \\
\text { serviceberry }\end{array}$ & AMUT & 679 & 0.949 & 0.972 & 0.972 & 0.882 \\
\hline Arctostaphylos patula & $\begin{array}{l}\text { greenleaf } \\
\text { manzanita }\end{array}$ & ARPA6 & 142 & 0.968 & 0.991 & 0.99 & 0.887 \\
\hline Arctostaphylos pringlei & $\begin{array}{l}\text { Pringle } \\
\text { manzanita }\end{array}$ & ARPR & 82 & 0.963 & 0.993 & 0.995 & 0.902 \\
\hline Arctostaphylos pungens & $\begin{array}{l}\text { pointleaf } \\
\text { manzanita }\end{array}$ & ARPU5 & 445 & 0.986 & 0.991 & 0.991 & 0.903 \\
\hline Arctostaphylos uva-ursi & $\begin{array}{l}\text { bearberry } \\
\text { manzanita }\end{array}$ & ARUV & 67 & 0.963 & 0.975 & 0.977 & 0.821 \\
\hline Artemisia arbuscula & low sagebrush & ARAR8 & 670 & 0.932 & 0.955 & 0.954 & 0.818 \\
\hline Artemisia bigelovii & $\begin{array}{l}\text { Bigelow's } \\
\text { sagebrush }\end{array}$ & ARBI3 & 411 & 0.972 & 0.987 & 0.987 & 0.912 \\
\hline Artemisia filifolia & $\begin{array}{l}\text { sand } \\
\text { sagebrush }\end{array}$ & ARFI2 & 555 & 0.942 & 0.971 & 0.968 & 0.874 \\
\hline Artemisia frigida & $\begin{array}{l}\text { fringed } \\
\text { sagewort }\end{array}$ & ARFR4 & 363 & 0.949 & 0.973 & 0.971 & 0.835 \\
\hline Artemisia nova & $\begin{array}{l}\text { black } \\
\text { sagebrush }\end{array}$ & ARNO4 & 2036 & 0.931 & 0.943 & 0.942 & 0.855 \\
\hline Artemisia tridentata (shrub) & big sagebrush & ARTR2 & $\begin{array}{r}1013 \\
9 \\
\end{array}$ & 0.834 & 0.843 & 0.839 & 0.874 \\
\hline Atriplex canescens & $\begin{array}{l}\text { fourwing } \\
\text { saltbush }\end{array}$ & ATCA2 & 2253 & 0.894 & 0.909 & 0.908 & 0.807 \\
\hline
\end{tabular}




\begin{tabular}{|c|c|c|c|c|c|c|c|}
\hline Species & 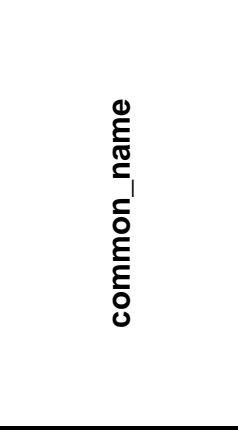 & 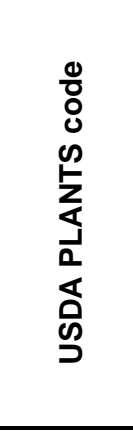 & 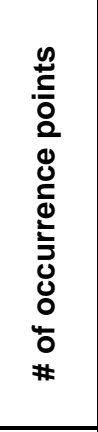 & 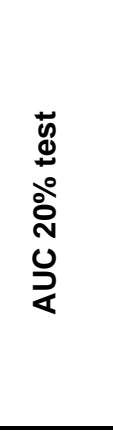 & 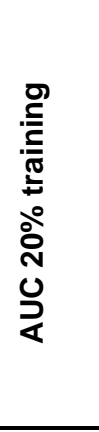 & 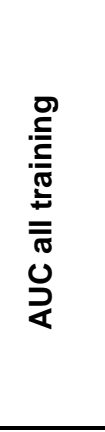 & 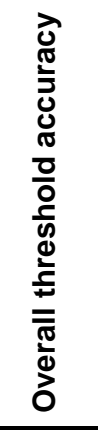 \\
\hline Atriplex confertifolia & $\begin{array}{l}\text { shadscale } \\
\text { saltbush }\end{array}$ & ATCO & 3515 & 0.909 & 0.92 & 0.918 & 0.871 \\
\hline Atriplex corrugata & mat saltbush & ATCO4 & 175 & 0.98 & 0.993 & 0.994 & 0.954 \\
\hline Atriplex gardneri & $\begin{array}{l}\text { Gardner's } \\
\text { saltbush }\end{array}$ & ATGA & 169 & 0.979 & 0.99 & 0.99 & 0.911 \\
\hline Atriplex hymenelytra & $\begin{array}{l}\text { Yuma desert } \\
\text { holly }\end{array}$ & ATHY & 183 & 0.992 & 0.996 & 0.996 & 0.934 \\
\hline Atriplex obovata & $\begin{array}{l}\text { mound } \\
\text { saltbush }\end{array}$ & ATOB & 325 & 0.991 & 0.996 & 0.996 & 0.954 \\
\hline Atriplex polycarpa & desert saltbush & ATPO & 144 & 0.939 & 0.977 & 0.977 & 0.854 \\
\hline Baccharis sarothroides & desert broom & BASA2 & 69 & 0.92 & 0.968 & 0.963 & 0.739 \\
\hline Canotia holacantha & canotia & $\mathrm{CAHO} 3$ & 290 & 0.99 & 0.996 & 0.996 & 0.941 \\
\hline Ceanothus greggii & $\begin{array}{l}\text { desert } \\
\text { ceanothus }\end{array}$ & CEGR & 322 & 0.989 & 0.992 & 0.992 & 0.898 \\
\hline Cercocarpus intricatus & $\begin{array}{l}\text { littleleaf } \\
\text { mountain } \\
\text { mahogany }\end{array}$ & CEIN7 & 76 & 0.947 & 0.965 & 0.964 & 0.803 \\
\hline Cercocarpus ledifolius & $\begin{array}{l}\text { curlleaf } \\
\text { mountain } \\
\text { mahogany }\end{array}$ & CELE3 & 422 & 0.966 & 0.979 & 0.978 & 0.858 \\
\hline Cercocarpus montanus & $\begin{array}{l}\text { true mountain } \\
\text { mahogany }\end{array}$ & CEMO2 & 1001 & 0.942 & 0.958 & 0.957 & 0.822 \\
\hline Chrysothamnus depressus & $\begin{array}{l}\text { dwarf } \\
\text { rabbitbrush }\end{array}$ & $\mathrm{CHDE} 2$ & 57 & 0.968 & 0.961 & 0.968 & 0.754 \\
\hline Chrysothamnus greenei & $\begin{array}{l}\text { Greene } \\
\text { rabbitbrush }\end{array}$ & CHGR6 & 1059 & 0.96 & 0.969 & 0.969 & 0.894 \\
\hline Chrysothamnus viscidiflorus & $\begin{array}{l}\text { Douglas' } \\
\text { rabbitbrush }\end{array}$ & CHVI8 & 2534 & 0.905 & 0.919 & 0.918 & 0.824 \\
\hline Coleogyne ramosissima & blackbrush & CORA & 1529 & 0.973 & 0.975 & 0.975 & 0.915 \\
\hline Encelia farinosa & $\begin{array}{l}\text { white } \\
\text { brittlebush }\end{array}$ & ENFA & 468 & 0.958 & 0.974 & 0.973 & 0.84 \\
\hline Ephedra nevadensis & $\begin{array}{l}\text { Nevada } \\
\text { mormon tea }\end{array}$ & EPNE & 2078 & 0.958 & 0.969 & 0.968 & 0.892 \\
\hline Ephedra torreyana & $\begin{array}{l}\text { Torrey } \\
\text { mormon tea }\end{array}$ & EPTO & 514 & 0.974 & 0.988 & 0.987 & 0.912 \\
\hline Ephedra trifurca & $\begin{array}{l}\text { longleaf } \\
\text { mormon tea }\end{array}$ & EPTR & 164 & 0.932 & 0.99 & 0.986 & 0.915 \\
\hline Ephedra viridis & mormon-tea & EPVI & 1816 & 0.921 & 0.937 & 0.935 & 0.845 \\
\hline Ericameria linearifolia & $\begin{array}{l}\text { slimleaf } \\
\text { goldenbush }\end{array}$ & ERLI6 & 70 & 0.992 & 0.996 & 0.995 & 0.886 \\
\hline Ericameria nauseosa & $\begin{array}{l}\text { rubber } \\
\text { rabbitbrush }\end{array}$ & CHNA2 & 267 & 0.945 & 0.977 & 0.974 & 0.843 \\
\hline Eriogonum fasciculatum & $\begin{array}{l}\text { yellow } \\
\text { buckwheat }\end{array}$ & ERFA2 & 560 & 0.982 & 0.983 & 0.983 & 0.886 \\
\hline Eriogonum wrightii & $\begin{array}{l}\text { shrubby } \\
\text { buckwheat }\end{array}$ & ERWR & 93 & 0.968 & 0.978 & 0.992 & 0.925 \\
\hline
\end{tabular}




\begin{tabular}{|c|c|c|c|c|c|c|c|}
\hline Species & 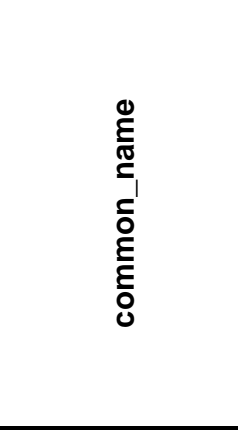 & $\begin{array}{l}0 \\
8 \\
0 \\
0 \\
5 \\
2 \\
0 \\
0 \\
0 \\
0 \\
0\end{array}$ & 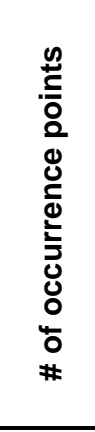 & 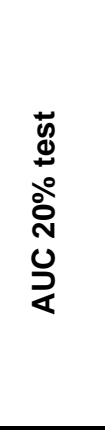 & 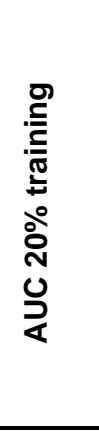 & 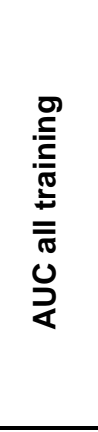 & 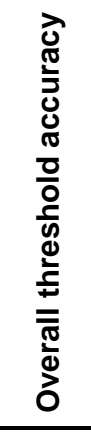 \\
\hline Fallugia paradoxa & Apache plume & FAPA & 219 & 0.939 & 0.979 & 0.978 & 0.863 \\
\hline Flourensia cernua & $\begin{array}{l}\text { American } \\
\text { tarwort }\end{array}$ & FLCE & 128 & 0.99 & 0.995 & 0.995 & 0.891 \\
\hline Fouquieria splendens & ocotillo & FOSP2 & 481 & 0.967 & 0.981 & 0.981 & 0.842 \\
\hline Garrya flavescens & $\begin{array}{l}\text { yellowleaf } \\
\text { silktassel }\end{array}$ & GAFL2 & 64 & 0.993 & 0.994 & 0.994 & 0.906 \\
\hline Garrya wrightii & $\begin{array}{l}\text { Wright's } \\
\text { silktassel }\end{array}$ & GAWR3 & 130 & 0.964 & 0.997 & 0.995 & 0.923 \\
\hline Grayia spinosa & spiny hopsage & GRSP & 1268 & 0.946 & 0.959 & 0.958 & 0.834 \\
\hline Gutierrezia microcephala & $\begin{array}{l}\text { threadleaf } \\
\text { snakeweed }\end{array}$ & GUMI & 334 & 0.948 & 0.968 & 0.968 & 0.859 \\
\hline Gutierrezia sarothrae & $\begin{array}{l}\text { broom } \\
\text { snakeweed }\end{array}$ & GUSA2 & 5052 & 0.828 & 0.837 & 0.836 & 0.782 \\
\hline Hymenoclea salsola & $\begin{array}{l}\text { white } \\
\text { burrobrush }\end{array}$ & HYSA & 1232 & 0.957 & 0.972 & 0.97 & 0.878 \\
\hline Juniperus communis & $\begin{array}{l}\text { common } \\
\text { juniper }\end{array}$ & JUCO6 & 501 & 0.976 & 0.981 & 0.98 & 0.892 \\
\hline Krascheninnikovia lanata & winterfat & KRLA2 & 1919 & 0.899 & 0.918 & 0.917 & 0.818 \\
\hline Larrea tridentata & creosote bush & LATR2 & 2978 & 0.946 & 0.951 & 0.949 & 0.876 \\
\hline Lupinus argenteus & silvery lupine & LUAR3 & 146 & 0.998 & 0.998 & 0.998 & 0.966 \\
\hline Lycium andersonii & $\begin{array}{l}\text { Anderson's } \\
\text { wolfberry }\end{array}$ & LYAN & 125 & 0.966 & 0.987 & 0.989 & 0.92 \\
\hline Lycium pallidum & pale wolfberry & LYPA & 172 & 0.918 & 0.977 & 0.971 & 0.855 \\
\hline Mahonia repens & $\begin{array}{l}\text { creeping } \\
\text { barberry }\end{array}$ & $\begin{array}{l}\text { MARE1 } \\
1 \\
\end{array}$ & 416 & 0.948 & 0.977 & 0.976 & 0.861 \\
\hline Menodora spinescens & $\begin{array}{l}\text { spiny } \\
\text { menodora }\end{array}$ & MESP2 & 220 & 0.978 & 0.994 & 0.993 & 0.918 \\
\hline Mimosa aculeaticarpa & mimosa & MIAC3 & 189 & 0.956 & 0.991 & 0.988 & 0.889 \\
\hline Opuntia basilaris & $\begin{array}{l}\text { beavertail } \\
\text { pricklypear }\end{array}$ & OPBA2 & 293 & 0.977 & 0.988 & 0.986 & 0.877 \\
\hline Opuntia engelmannii & cactus apple & OPEN3 & 205 & 0.966 & 0.99 & 0.99 & 0.917 \\
\hline Parthenium incanum & mariola & PAIN2 & 58 & 0.978 & 0.987 & 0.986 & 0.828 \\
\hline Paxistima myrsinites & $\begin{array}{l}\text { Oregon } \\
\text { boxleaf }\end{array}$ & PAMY & 112 & 0.964 & 0.991 & 0.99 & 0.866 \\
\hline Picrothamnus desertorum & bud sagebrush & PIDE4 & 963 & 0.961 & 0.971 & 0.971 & 0.874 \\
\hline Prunus fasciculata & desert almond & PRFA & 70 & 0.981 & 0.982 & 0.986 & 0.857 \\
\hline Prunus virginiana & chokecherry & PRVI & 326 & 0.956 & 973 & 0.973 & 0.813 \\
\hline Purshia mexicana & $\begin{array}{l}\text { Mexican } \\
\text { cliffrose }\end{array}$ & PUME & 391 & 0.98 & 0.983 & 0.983 & 0.88 \\
\hline Purshia stansburiana & $\begin{array}{l}\text { stansbury } \\
\text { cliffrose }\end{array}$ & PUST & 469 & 0.939 & 0.971 & 0.967 & 0.866 \\
\hline Purshia tridentata & $\begin{array}{l}\text { antelope } \\
\text { bitterbrush }\end{array}$ & PUTR2 & 927 & 0.909 & 0.943 & 0.94 & 0.834 \\
\hline
\end{tabular}




\begin{tabular}{|c|c|c|c|c|c|c|c|}
\hline Species & 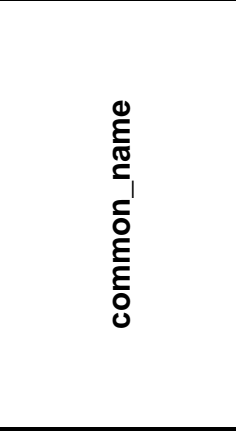 & 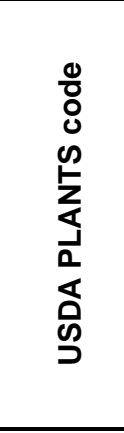 & 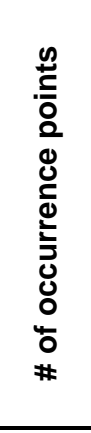 & 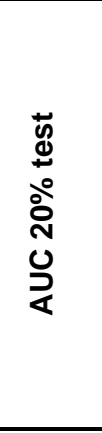 & 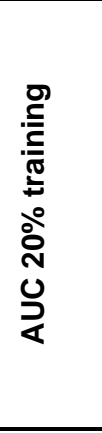 & 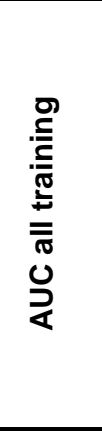 & 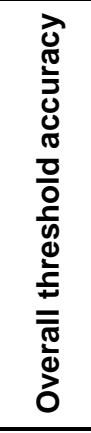 \\
\hline Quercus turbinella & turbinella oak & QUTU2 & 1074 & 0.972 & 0.983 & 0.982 & 0.91 \\
\hline Rhus microphylla & littleleaf sumac & RHMI3 & 71 & 0.964 & 0.985 & 0.982 & 0.789 \\
\hline Rhus ovata & sugar sumac & RHOV & 51 & 0.996 & 0.994 & 0.995 & 0.824 \\
\hline Rhus trilobata & $\begin{array}{l}\text { skunkbush } \\
\text { sumac }\end{array}$ & RHTR & 582 & 0.924 & 0.955 & 0.951 & 0.816 \\
\hline Ribes cereum & wax currant & RICE & 179 & 0.938 & 0.986 & 0.982 & 0.877 \\
\hline Ribes montigenum & $\begin{array}{l}\text { gooseberry } \\
\text { current }\end{array}$ & RIMO2 & 132 & 0.954 & 0.991 & 0.99 & 0.856 \\
\hline Robinia neomexicana & $\begin{array}{l}\text { New Mexico } \\
\text { locust }\end{array}$ & RONE & 209 & 0.988 & 0.993 & 0.993 & 0.88 \\
\hline Rosa woodsii & Wood's rose & ROWO & 489 & 0.938 & 0.947 & 0.949 & 0.796 \\
\hline Salazaria mexicana & $\begin{array}{l}\text { Mexican } \\
\text { bladdersage }\end{array}$ & SAME & 348 & 0.986 & 0.99 & 0.989 & 0.879 \\
\hline Salix geyeriana & geyer willow & SAGE2 & 67 & 0.96 & 0.974 & 0.975 & 0.731 \\
\hline Sarcobatus vermiculatus & $\begin{array}{l}\text { black } \\
\text { greasewood }\end{array}$ & SAVE4 & 2131 & 0.92 & 0.932 & 0.93 & 0.841 \\
\hline Shepherdia canadensis & $\begin{array}{l}\text { russet } \\
\text { buffaloberry }\end{array}$ & SHCA & 66 & 0.972 & 0.984 & 0.983 & 0.758 \\
\hline Simmondsia chinensis & jojoba & $\mathrm{SICH}$ & 139 & 0.991 & 0.997 & 0.996 & 0.95 \\
\hline Suaeda moquinii & $\begin{array}{l}\text { Torrey } \\
\text { seepweed }\end{array}$ & SUMO & 214 & 0.962 & 0.991 & 0.99 & 0.907 \\
\hline Symphoricarpos albus & $\begin{array}{l}\text { common } \\
\text { snowberry }\end{array}$ & SYAL & 283 & 0.976 & 0.986 & 0.986 & 0.88 \\
\hline Symphoricarpos oreophilus & $\begin{array}{l}\text { mountain } \\
\text { snowberry }\end{array}$ & SYOR2 & 1218 & 0.964 & 0.971 & 0.97 & 0.876 \\
\hline Symphoricarpos rotundifolius & $\begin{array}{l}\text { roundleaf } \\
\text { snowberry }\end{array}$ & SYRO & 207 & 0.993 & 0.993 & 0.993 & 0.908 \\
\hline Tetradymia glabrata & $\begin{array}{l}\text { littleleaf } \\
\text { horsebrush }\end{array}$ & TEGL & 365 & 0.957 & 0.971 & 0.971 & 0.83 \\
\hline Tetradymia spinosa & $\begin{array}{l}\text { shortspine } \\
\text { horsebrush }\end{array}$ & TESP2 & 113 & 0.991 & 0.995 & 0.996 & 0.912 \\
\hline Vaccinium myrtillus & $\begin{array}{l}\text { myrtle } \\
\text { blueberry }\end{array}$ & VAMY2 & 125 & 0.989 & 0.989 & 0.99 & 0.872 \\
\hline Vaccinium scoparium & $\begin{array}{l}\text { grouse } \\
\text { whortleberry }\end{array}$ & VASC & 101 & 0.992 & 0.996 & 0.997 & 0.941 \\
\hline Yucca angustissima & $\begin{array}{l}\text { narrowleaf } \\
\text { yucca }\end{array}$ & YUAN2 & 696 & 0.978 & 0.984 & 0.984 & 0.908 \\
\hline Yucca baccata & banana yucca & YUBA & 1065 & 0.937 & 0.958 & 0.957 & 0.843 \\
\hline Yucca elata & soaptree yucca & YUEL & 385 & 0.958 & 0.972 & 0.971 & 0.818 \\
\hline Yucca glauca & $\begin{array}{l}\text { small } \\
\text { soapweed }\end{array}$ & YUGL & 356 & 0.943 & 0.966 & 0.964 & 0.787 \\
\hline Yucca schidigera & mojave yucca & YUSC2 & 223 & 0.988 & 0.993 & 0.993 & 0.901 \\
\hline Ziziphus obtusifolia & graythorn & ZIOB & 69 & 0.977 & 0.993 & 0.991 & 0.812 \\
\hline Grasses & & & & & & & \\
\hline
\end{tabular}




\begin{tabular}{|c|c|c|c|c|c|c|c|}
\hline Species & 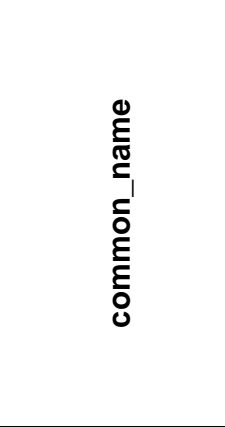 & 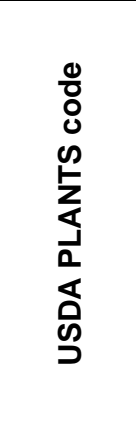 & 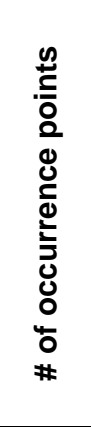 & 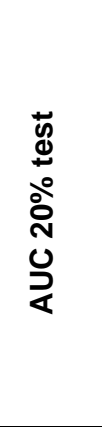 & 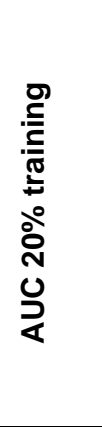 & 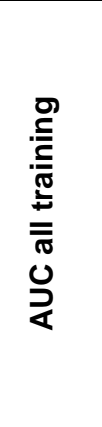 & 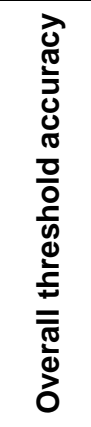 \\
\hline Achnatherum hymenoides & $\begin{array}{l}\text { Indian } \\
\text { ricegrass }\end{array}$ & $\mathrm{ACHY}$ & 3384 & 0.87 & 0.884 & 0.881 & 0.796 \\
\hline Achnatherum speciosum & $\begin{array}{l}\text { desert } \\
\text { needlegrass }\end{array}$ & $\begin{array}{l}\text { ACSP1 } \\
2\end{array}$ & 61 & 0.923 & 0.981 & 0.982 & 0.836 \\
\hline Achnatherum thurberianum & $\begin{array}{l}\text { Thurber's } \\
\text { needlegrass }\end{array}$ & ACTH7 & 66 & 0.988 & 0.975 & 0.978 & 0.727 \\
\hline Bouteloua curtipendula & $\begin{array}{l}\text { sideoats } \\
\text { grama }\end{array}$ & $\mathrm{BOCU}$ & 844 & 0.944 & 0.95 & 0.95 & 0.78 \\
\hline Bouteloua eriopoda & black grama & BOER4 & 523 & 0.938 & 0.955 & 0.955 & 0.849 \\
\hline Bouteloua gracilis & blue grama & BOGR2 & 4538 & 0.899 & 0.902 & 0.901 & 0.838 \\
\hline Bouteloua hirsuta & hairy grama & $\mathrm{BOH} 2$ & 187 & 0.963 & 0.976 & 0.976 & 0.834 \\
\hline Dasyochloa pulchella & fluffgrass & DAPU7 & 133 & 0.956 & 0.987 & 0.987 & 0.895 \\
\hline Elymus elymoides & $\begin{array}{l}\text { bottlebrush } \\
\text { squirreltail }\end{array}$ & ELEL5 & 1592 & 0.879 & 0.904 & 0.902 & 0.788 \\
\hline Elymus glaucus & blue wildrye & ELGL & 143 & 0.996 & 0.993 & 0.994 & 0.895 \\
\hline Elymus trachycaulus & $\begin{array}{l}\text { slender wild } \\
\text { rye }\end{array}$ & ELTR7 & 234 & 0.855 & 0.946 & 0.942 & 0.799 \\
\hline Festuca arizonica & Arizona fescue & FEAR2 & 604 & 0.983 & 0.991 & 0.99 & 0.925 \\
\hline Festuca brachyphylla & alpine fescue & FEBR & 130 & 0.992 & 0.994 & 0.995 & 0.938 \\
\hline Festuca idahoensis & Idaho fescue & FEID & 130 & 0.965 & 0.989 & 0.989 & 0.892 \\
\hline Festuca thurberi & $\begin{array}{l}\text { Thurber's } \\
\text { fescue }\end{array}$ & FETH & 80 & 0.966 & 0.989 & 0.995 & 0.9 \\
\hline Hesperostipa comata & hesperostipa & $\begin{array}{l}\mathrm{HECO} 2 \\
6\end{array}$ & 1074 & 0.882 & 0.917 & 0.914 & 0.811 \\
\hline Hilaria belangeri & $\begin{array}{l}\text { curley } \\
\text { mesquite }\end{array}$ & HIBE & 70 & 0.992 & 0.994 & 0.994 & 0.871 \\
\hline Hordeum jubatum & foxtail barley & HOJU & 217 & 0.919 & 0.966 & 0.963 & 0.82 \\
\hline Koeleria macrantha & $\begin{array}{l}\text { prairie } \\
\text { junegrass }\end{array}$ & KOMA & 491 & 0.972 & 0.98 & 0.981 & 0.884 \\
\hline Leymus cinereus & basin wildrye & LECI4 & 386 & 0.924 & 0.957 & 0.955 & 0.803 \\
\hline Muhlenbergia emersleyi & bullgrass & MUEM & 58 & 0.988 & 0.992 & 0.992 & 0.828 \\
\hline Muhlenbergia montana & $\begin{array}{l}\text { mountain } \\
\text { muhly }\end{array}$ & MUMO & 447 & 0.967 & 0.989 & 0.986 & 0.864 \\
\hline Muhlenbergia porteri & bush muhly & MUPO2 & 195 & 0.939 & 0.984 & 0.98 & 0.862 \\
\hline Pascopyrum smithii & $\begin{array}{l}\text { western } \\
\text { wheatgrass }\end{array}$ & PASM & 602 & 0.923 & 0.941 & 0.941 & 0.787 \\
\hline Pleuraphis jamesii & galleta & PLJA & 3165 & 0.909 & 0.918 & 0.917 & 0.841 \\
\hline Pleuraphis mutica & tobosa & PLMU3 & 436 & 0.961 & 0.977 & 0.976 & 0.826 \\
\hline Pleuraphis rigida & big galleta & PLRI3 & 307 & 0.965 & 0.981 & 0.981 & 0.86 \\
\hline Poa fendleriana & muttongrass & POFE & 1370 & 0.974 & 0.984 & 0.983 & 0.924 \\
\hline Poa secunda & big bluegrass & POSE & 1757 & 0.924 & 0.938 & 0.937 & 0.837 \\
\hline Schizachyrium scoparium & little bluestem & Scsc & 70 & 0.95 & 0.946 & 0.954 & 0.743 \\
\hline
\end{tabular}




\begin{tabular}{|c|c|c|c|c|c|c|c|}
\hline Species & 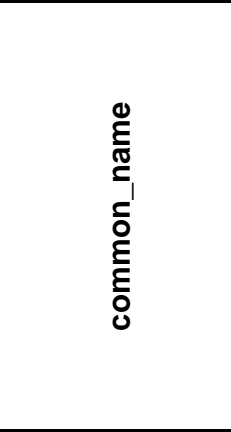 & 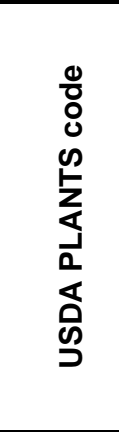 & 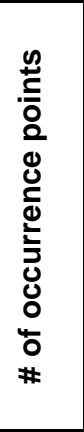 & 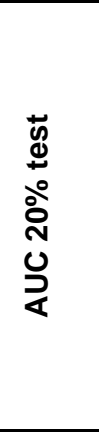 & 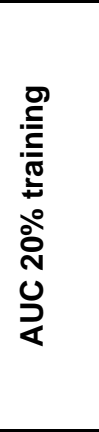 & 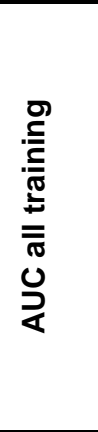 & 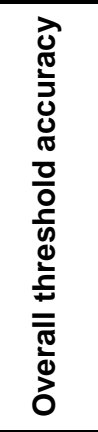 \\
\hline Sporobolus airoides & alkali sacaton & SPAI & 798 & 0.958 & 0.975 & 0.975 & 0.876 \\
\hline Sporobolus cryptandrus & sand dropseed & SPCR & 641 & 0.861 & 0.927 & 0.921 & 0.799 \\
\hline Sporobolus flexuosus & $\begin{array}{l}\text { mesa } \\
\text { dropseed }\end{array}$ & SPFL2 & 104 & 0.981 & 0.985 & 0.99 & 0.904 \\
\hline
\end{tabular}


Table 2. Suitable habitat predictions for the study plant species $(n=166)$ showing the predicted modern-day proportion of the study area $(S)$ and the percent of the modern-day suitable habitat (SH) predicted in the future to be decreasing suitability (DS), increasing suitability (IS), and maintained suitability (MS). The future SH predictions were based on climate models based on 2007 IPPC emission scenarios B1 (global temperature rise of $2.4^{\circ} \mathrm{C}$ ), A1B (global temperature rise of $2.8^{\circ} \mathrm{C}$ ), and $\mathrm{A} 2$ (global temperature rise of $3.4^{\circ} \mathrm{C}$ ) for the time period 2050 (2040-2069) and 2100 (2070-2100) as compiled by the Climate Wizard collaboration. 


\begin{tabular}{|c|c|c|c|c|c|c|c|c|}
\hline \multirow[b]{3}{*}{ Species } & \multirow{2}{*}{ 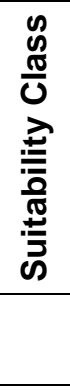 } & \multirow{3}{*}{ 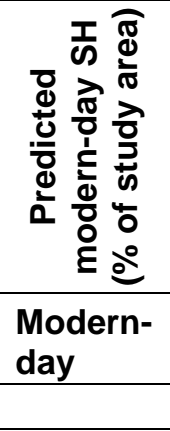 } & \multicolumn{6}{|c|}{$\begin{array}{l}\text { Predicted future SH (\% of modern-day SH } \\
\text { area) by scenario and time-period }\end{array}$} \\
\hline & & & \multicolumn{2}{|c|}{ B1 (Low) } & \multicolumn{2}{|c|}{$\begin{array}{c}\text { A1B } \\
\text { (Medium) }\end{array}$} & \multicolumn{2}{|c|}{ A2 (High) } \\
\hline & & & 2050 & 2100 & 2050 & 2100 & 2050 & 2100 \\
\hline \multicolumn{9}{|l|}{ Trees } \\
\hline \multirow[t]{4}{*}{ Abies concolor } & $\mathrm{SH}$ & 5.2 & & & & & & \\
\hline & DS & & 69.5 & 78.3 & 74.3 & 68 & 69.9 & 82.1 \\
\hline & IS & & 20.7 & 19.5 & 27 & 38.6 & 21.9 & 31.1 \\
\hline & MS & & 30.5 & 21.7 & 25.7 & 32 & 30.1 & 17.9 \\
\hline \multirow[t]{4}{*}{ Abies lasiocarpa } & $\mathrm{SH}$ & 3.9 & & & & & & \\
\hline & DS & & 49.5 & 53.9 & 48.3 & 51.7 & 44 & 59.1 \\
\hline & IS & & 30 & 24.3 & 27.8 & 25.9 & 37.2 & 21.6 \\
\hline & MS & & 50.5 & 46.1 & 51.7 & 48.3 & 56 & 40.9 \\
\hline \multirow[t]{4}{*}{ Acer glabrum } & $\mathrm{SH}$ & 2.2 & & & & & & \\
\hline & DS & & 34.8 & 37.5 & 40.7 & 45.9 & 33.1 & 45.7 \\
\hline & IS & & 137.5 & 169.9 & 157.9 & 168.4 & 168.9 & 222.8 \\
\hline & MS & & 65.2 & 62.5 & 59.3 & 54.1 & 66.9 & 54.3 \\
\hline \multirow[t]{4}{*}{$\begin{array}{l}\text { Acer } \\
\text { grandidentatum }\end{array}$} & $\mathrm{SH}$ & 1.3 & & & & & & \\
\hline & DS & & 53.2 & 51 & 50.2 & 49.7 & 50.7 & 55.4 \\
\hline & IS & & 83.4 & 100.1 & 100.4 & 140.3 & 99.7 & 170.9 \\
\hline & MS & & 46.8 & 49 & 49.8 & 50.3 & 49.3 & 44.6 \\
\hline \multirow[t]{4}{*}{ Acer negundo } & $\mathrm{SH}$ & 3.1 & & & & & & \\
\hline & DS & & 64.5 & 77.7 & 73.7 & 71.5 & 70.1 & 70.1 \\
\hline & IS & & 109 & 109.7 & 117.8 & 176.7 & 147.2 & 215.5 \\
\hline & MS & & 35.5 & 22.3 & 26.3 & 28.5 & 29.9 & 29.9 \\
\hline \multirow[t]{4}{*}{$\begin{array}{l}\text { Carnegiea } \\
\text { gigantea }\end{array}$} & $\mathrm{SH}$ & 2.5 & & & & & & \\
\hline & DS & & 67.2 & 74.9 & 77.1 & 40.2 & 21.6 & 76.4 \\
\hline & IS & & 23.2 & 49.9 & 33.5 & 70.2 & 116.5 & 32.9 \\
\hline & MS & & 32.8 & 25.1 & 22.9 & 59.8 & 78.4 & 23.6 \\
\hline \multirow[t]{4}{*}{ Fraxinus velutina } & $\mathrm{SH}$ & 1.7 & & & & & & \\
\hline & DS & & 80.8 & 91 & 98.1 & 90.3 & 79 & 89.2 \\
\hline & IS & & 32.1 & 28.1 & 19.8 & 67.4 & 62.9 & 60.1 \\
\hline & $\mathrm{MS}$ & & 19.2 & 9 & 1.9 & 9.7 & 21 & 10.8 \\
\hline \multirow[t]{4}{*}{ Juglans major } & $\mathrm{SH}$ & 2.3 & & & & & & \\
\hline & DS & & 84.7 & 93.3 & 92.1 & 90.7 & 83.1 & 78.9 \\
\hline & IS & & 32.4 & 19.9 & 14.9 & 53.9 & 29.3 & 95.4 \\
\hline & MS & & 15.3 & 6.7 & 7.9 & 9.3 & 16.9 & 21.1 \\
\hline \multirow[t]{4}{*}{$\begin{array}{l}\text { Juniperus } \\
\text { coahuilensis }\end{array}$} & $\mathrm{SH}$ & 1 & & & & & & \\
\hline & DS & & 78.1 & 78.1 & 77 & 67.1 & 36.2 & 65.5 \\
\hline & IS & & 36.8 & 50.1 & 72 & 121.7 & 197.2 & 342.6 \\
\hline & MS & & 21.9 & 21.9 & 23 & 32.9 & 63.8 & 34.5 \\
\hline
\end{tabular}




\begin{tabular}{|c|c|c|c|c|c|c|c|c|}
\hline \multirow[b]{3}{*}{ Species } & \multirow{3}{*}{ 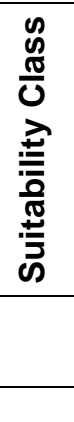 } & \multirow{3}{*}{ 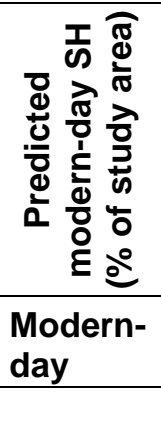 } & \multicolumn{6}{|c|}{$\begin{array}{l}\text { Predicted future } \mathrm{SH} \text { (\% of modern-day } \mathrm{SH} \\
\text { area) by scenario and time-period }\end{array}$} \\
\hline & & & \multicolumn{2}{|c|}{ B1 (Low) } & \multicolumn{2}{|c|}{$\begin{array}{c}\text { A1B } \\
\text { (Medium) }\end{array}$} & \multicolumn{2}{|c|}{ A2 (High) } \\
\hline & & & 2050 & 2100 & 2050 & 2100 & 2050 & 2100 \\
\hline \multirow[t]{4}{*}{$\begin{array}{l}\text { Juniperus } \\
\text { deppeana }\end{array}$} & $\mathrm{SH}$ & 4 & & & & & & \\
\hline & DS & & 48.7 & 63.4 & 64.5 & 66 & 56.1 & 71.2 \\
\hline & IS & & 21.8 & 17 & 20.3 & 30.4 & 22 & 29 \\
\hline & MS & & 51.3 & 36.6 & 35.5 & 34 & 43.9 & 28.8 \\
\hline \multirow[t]{4}{*}{$\begin{array}{l}\text { Juniperus } \\
\text { monosperma }\end{array}$} & $\mathrm{SH}$ & 15.1 & & & & & & \\
\hline & DS & & 39.8 & 63.5 & 65.9 & 65.7 & 63.4 & 84 \\
\hline & IS & & 27 & 27.7 & 29 & 29.8 & 20.4 & 30.7 \\
\hline & MS & & 60.2 & 36.5 & 34.1 & 34.3 & 36.6 & 16 \\
\hline \multirow[t]{4}{*}{$\begin{array}{l}\text { Juniperus } \\
\text { osteosperma }\end{array}$} & $\mathrm{SH}$ & 22.2 & & & & & & \\
\hline & DS & & 52.3 & 53.9 & 52.7 & 45.9 & 50.2 & 63.1 \\
\hline & IS & & 19 & 19.5 & 27.1 & 34.3 & 20.4 & 26.9 \\
\hline & MS & & 47.7 & 46.1 & 47.3 & 54.1 & 49.8 & 36.9 \\
\hline \multirow[t]{4}{*}{$\begin{array}{l}\text { Juniperus } \\
\text { scopulorum }\end{array}$} & $\mathrm{SH}$ & 9.9 & & & & & & \\
\hline & DS & & 57.8 & 65.3 & 74.9 & 73.4 & 73.9 & 82.3 \\
\hline & IS & & 39.4 & 45 & 31.2 & 45.9 & 29 & 38.8 \\
\hline & MS & & 42.2 & 34.7 & 25.1 & 26.6 & 26.1 & 17.7 \\
\hline \multirow[t]{4}{*}{ Olneya tesota } & $\mathrm{SH}$ & 1.7 & & & & & & \\
\hline & DS & & 55.9 & 41.4 & 44.4 & 45.3 & 34.3 & 38.9 \\
\hline & IS & & 43.9 & 89.4 & 86 & 71.3 & 122.9 & 113.5 \\
\hline & MS & & 44.1 & 58.6 & 55.6 & 54.7 & 65.7 & 61.1 \\
\hline \multirow[t]{4}{*}{$\begin{array}{l}\text { Parkinsonia } \\
\text { florida }\end{array}$} & $\mathrm{SH}$ & 2.8 & & & & & & \\
\hline & DS & & 69 & 62.3 & 77.4 & 74 & 33.7 & 81.9 \\
\hline & IS & & 124.8 & 256.6 & 163.4 & 131.2 & 204.5 & 167.7 \\
\hline & MS & & 31 & 37.7 & 22.6 & 26 & 66.3 & 18.1 \\
\hline \multirow[t]{4}{*}{$\begin{array}{l}\text { Parkinsonia } \\
\text { microphylla }\end{array}$} & $\mathrm{SH}$ & 2.7 & & & & & & \\
\hline & DS & & 43.3 & 50.2 & 49.6 & 35.4 & 24.9 & 49.5 \\
\hline & IS & & 30.5 & 50.7 & 49.7 & 97.6 & 102.7 & 79 \\
\hline & MS & & 56.7 & 49.8 & 50.4 & 64.6 & 75.1 & 50.5 \\
\hline \multirow[t]{4}{*}{$\begin{array}{l}\text { Picea } \\
\text { engelmannii }\end{array}$} & $\mathrm{SH}$ & 5.1 & & & & & & \\
\hline & DS & & 46.9 & 53.7 & 54.3 & 60.2 & 48.3 & 67.7 \\
\hline & IS & & 18.7 & 14.5 & 13.7 & 12.7 & 17.2 & 10.4 \\
\hline & MS & & 53.1 & 46.3 & 45.7 & 39.8 & 51.7 & 32.3 \\
\hline Picea pungens & $\mathrm{SH}$ & 2.9 & & & & & & \\
\hline
\end{tabular}




\begin{tabular}{|c|c|c|c|c|c|c|c|c|}
\hline \multirow[b]{3}{*}{ Species } & \multirow{3}{*}{ 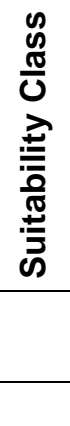 } & \multirow{3}{*}{ 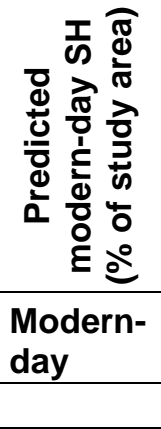 } & \multicolumn{6}{|c|}{$\begin{array}{l}\text { Predicted future SH (\% of modern-day SH } \\
\text { area) by scenario and time-period }\end{array}$} \\
\hline & & & \multicolumn{2}{|c|}{ B1 (Low) } & \multicolumn{2}{|c|}{$\begin{array}{c}\text { A1B } \\
\text { (Medium) }\end{array}$} & \multicolumn{2}{|c|}{ A2 (High) } \\
\hline & & & 2050 & 2100 & 2050 & 2100 & 2050 & 2100 \\
\hline & DS & & 60.2 & 72.3 & 70.8 & 76.2 & 64.1 & 79.9 \\
\hline & IS & & 95.4 & 78.5 & 77.8 & 70.1 & 94.3 & 87.5 \\
\hline & MS & & 39.8 & 27.7 & 29.2 & 23.8 & 35.9 & 20.1 \\
\hline \multirow[t]{4}{*}{ Pinus aristata } & $\mathrm{SH}$ & 1 & & & & & & \\
\hline & DS & & 55 & 80 & 87 & 84.3 & 87.7 & 98 \\
\hline & IS & & 73.1 & 51.5 & 29 & 59.6 & 15.9 & 12.5 \\
\hline & MS & & 45 & 20 & 13 & 15.7 & 12.3 & 2 \\
\hline \multirow[t]{4}{*}{ Pinus contorta } & $\mathrm{SH}$ & 2.5 & & & & & & \\
\hline & DS & & 44.9 & 52.4 & 53.5 & 79.3 & 42.7 & 88.1 \\
\hline & IS & & 44.2 & 38.3 & 41.3 & 20.4 & 53.6 & 13.8 \\
\hline & MS & & 55.1 & 47.6 & 46.5 & 20.7 & 57.3 & 11.9 \\
\hline \multirow[t]{4}{*}{ Pinus edulis } & $\mathrm{SH}$ & 17.1 & & & & & & \\
\hline & DS & & 47.1 & 58.9 & 59.8 & 63.7 & 63.5 & 78.2 \\
\hline & IS & & 26.3 & 37.2 & 30.2 & 45.2 & 22.9 & 39.7 \\
\hline & MS & & 52.9 & 41.1 & 40.2 & 36.3 & 36.5 & 21.8 \\
\hline \multirow[t]{4}{*}{ Pinus flexilis } & $\mathrm{SH}$ & 4.1 & & & & & & \\
\hline & DS & & 86.4 & 95.8 & 94.5 & 95.7 & 95.9 & 98.7 \\
\hline & IS & & 20.4 & 8.8 & 11.1 & 19.2 & 5.1 & 6.5 \\
\hline & MS & & 13.6 & 4.2 & 5.5 & 4.3 & 4.1 & 1.3 \\
\hline \multirow[t]{4}{*}{ Pinus monophylla } & $\mathrm{SH}$ & 10 & & & & & & \\
\hline & DS & & 78.4 & 87.9 & 79 & 87.9 & 78.9 & 97.1 \\
\hline & IS & & 7.8 & 4.4 & 13.7 & 13.1 & 15.1 & 5.4 \\
\hline & MS & & 21.6 & 12.1 & 21 & 12.1 & 21.1 & 2.9 \\
\hline \multirow[t]{4}{*}{ Pinus ponderosa } & $\mathrm{SH}$ & 9.7 & & & & & & \\
\hline & DS & & 60.7 & 76 & 79.4 & 82.5 & 71.5 & 88.4 \\
\hline & IS & & 15.5 & 21.5 & 16.4 & 26.7 & 15.1 & 25.7 \\
\hline & MS & & 39.3 & 24 & 20.6 & 17.5 & 28.5 & 11.6 \\
\hline \multirow[t]{4}{*}{ Pinus strobiformis } & $\mathrm{SH}$ & 0.3 & & & & & & \\
\hline & DS & & 68.6 & 80 & 94.1 & 94.7 & 67.3 & 90.7 \\
\hline & IS & & 19.6 & 7.6 & 17.3 & 2.6 & 18.7 & 14.5 \\
\hline & MS & & 31.4 & 20 & 5.9 & 5.3 & 32.7 & 9.3 \\
\hline \multirow[t]{4}{*}{$\begin{array}{l}\text { Populus } \\
\text { angustifolia }\end{array}$} & $\mathrm{SH}$ & 9.8 & & & & & & \\
\hline & DS & & 59.9 & 69.9 & 76.8 & 84.2 & 75 & 90.5 \\
\hline & IS & & 43.9 & 44.8 & 34.3 & 35 & 35.5 & 38.2 \\
\hline & MS & & 40.1 & 30.1 & 23.2 & 15.8 & 25 & 9.5 \\
\hline \multirow[t]{2}{*}{$\begin{array}{l}\text { Populus } \\
\text { tremuloides }\end{array}$} & $\mathrm{SH}$ & 8.7 & & & & & & \\
\hline & DS & & 45 & 57.9 & 57 & 66.2 & 51.7 & 73.7 \\
\hline
\end{tabular}




\begin{tabular}{|c|c|c|c|c|c|c|c|c|}
\hline \multirow[b]{3}{*}{ Species } & \multirow{3}{*}{ 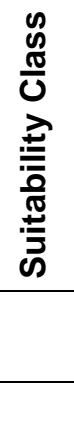 } & \multirow{3}{*}{ 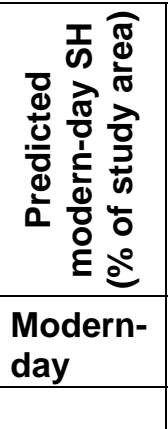 } & \multicolumn{6}{|c|}{$\begin{array}{l}\text { Predicted future } \mathrm{SH} \text { (\% of modern-day } \mathrm{SH} \\
\text { area) by scenario and time-period }\end{array}$} \\
\hline & & & \multicolumn{2}{|c|}{ B1 (Low) } & \multicolumn{2}{|c|}{$\begin{array}{c}\text { A1B } \\
\text { (Medium) }\end{array}$} & \multicolumn{2}{|c|}{ A2 (High) } \\
\hline & & & 2050 & 2100 & 2050 & 2100 & 2050 & 2100 \\
\hline & IS & & 30.5 & 24.7 & 26.4 & 25.3 & 30.1 & 24.3 \\
\hline & MS & & 55 & 42.1 & 43 & 33.8 & 48.3 & 26.3 \\
\hline \multirow[t]{4}{*}{$\begin{array}{l}\text { Prosopis } \\
\text { glandulosa }\end{array}$} & $\mathrm{SH}$ & 8.8 & & & & & & \\
\hline & DS & & 9.2 & 25.5 & 35.4 & 49.6 & 37.8 & 66.2 \\
\hline & IS & & 100.8 & 137.7 & 103.6 & 126.6 & 59.3 & 172.3 \\
\hline & MS & & 90.8 & 74.5 & 64.6 & 50.4 & 62.2 & 33.8 \\
\hline \multirow[t]{4}{*}{ Prosopis velutina } & $\mathrm{SH}$ & 4.7 & & & & & & \\
\hline & DS & & 23.3 & 33 & 33.8 & 15.7 & 9.6 & 25.8 \\
\hline & IS & & 94.2 & 93.6 & 98.3 & 140.4 & 127.5 & 158.9 \\
\hline & MS & & 76.7 & 67 & 66.2 & 84.3 & 90.4 & 74.2 \\
\hline \multirow[t]{4}{*}{$\begin{array}{l}\text { Pseudotsuga } \\
\text { menziesii }\end{array}$} & $\mathrm{SH}$ & 8.6 & & & & & & \\
\hline & DS & & 46.8 & 57.8 & 60 & 62.3 & 57 & 69.6 \\
\hline & IS & & 30 & 30.3 & 29.9 & 35.9 & 31.3 & 39.7 \\
\hline & MS & & 53.2 & 42.2 & 40 & 37.7 & 43 & 30.4 \\
\hline \multirow[t]{4}{*}{ Quercus arizonica } & $\mathrm{SH}$ & 1 & & & & & & \\
\hline & DS & & 86 & 84.4 & 92.1 & 81.7 & 79.5 & 85.5 \\
\hline & IS & & 52.6 & 64.4 & 31.6 & 91 & 80.1 & 77.9 \\
\hline & MS & & 14 & 15.6 & 7.9 & 18.3 & 20.5 & 14.5 \\
\hline \multirow[t]{4}{*}{ Quercus emoryi } & $\mathrm{SH}$ & 2.1 & & & & & & \\
\hline & DS & & 69.6 & 80.1 & 69.3 & 75.6 & 63.1 & 78.4 \\
\hline & IS & & 29.4 & 33.6 & 59.4 & 79.1 & 58.3 & 69.4 \\
\hline & MS & & 30.4 & 19.9 & 30.7 & 24.4 & 36.9 & 21.6 \\
\hline \multirow[t]{4}{*}{ Quercus gambelii } & $\mathrm{SH}$ & 10.5 & & & & & & \\
\hline & DS & & 45.2 & 57.7 & 61.8 & 67.9 & 56.5 & 73.7 \\
\hline & IS & & 43.1 & 47.5 & 43.8 & 52.6 & 42.2 & 54.4 \\
\hline & MS & & 54.8 & 42.3 & 38.2 & 32.1 & 43.5 & 26.3 \\
\hline \multirow[t]{4}{*}{ Quercus grisea } & $\mathrm{SH}$ & 2.4 & & & & & & \\
\hline & DS & & 65.3 & 93.4 & 94.5 & 90.9 & 87 & 85.9 \\
\hline & IS & & 54 & 26.2 & 18.1 & 23.3 & 36.5 & 45.1 \\
\hline & MS & & 34.7 & 6.6 & 5.5 & 9.1 & 13 & 14.1 \\
\hline \multirow[t]{4}{*}{ Quercus havardii } & $\mathrm{SH}$ & 1.8 & & & & & & \\
\hline & DS & & 67.1 & 67.8 & 74.2 & 97.4 & 80.4 & 94.5 \\
\hline & IS & & 154.2 & 185.1 & 110.2 & 23.2 & 67.7 & 55.2 \\
\hline & MS & & 32.9 & 32.2 & 25.8 & 2.6 & 19.6 & 5.5 \\
\hline \multirow[t]{3}{*}{ Yucca brevifolia } & $\mathrm{SH}$ & 3.9 & & & & & & \\
\hline & DS & & 72.3 & 88.6 & 75 & 84.8 & 60.1 & 94.9 \\
\hline & IS & & 46.3 & 31.1 & 99.3 & 139.9 & 108.1 & 53.4 \\
\hline
\end{tabular}




\begin{tabular}{|c|c|c|c|c|c|c|c|c|}
\hline \multirow[b]{3}{*}{ Species } & \multirow{3}{*}{ 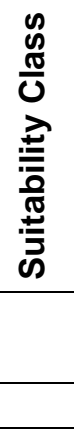 } & \multirow{3}{*}{ 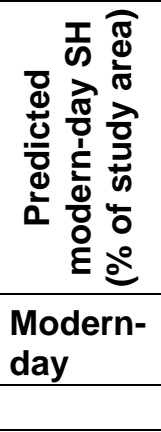 } & \multicolumn{6}{|c|}{$\begin{array}{l}\text { Predicted future SH (\% of modern-day SH } \\
\text { area) by scenario and time-period }\end{array}$} \\
\hline & & & \multicolumn{2}{|c|}{ B1 (Low) } & \multicolumn{2}{|c|}{$\begin{array}{c}\text { A1B } \\
\text { (Medium) }\end{array}$} & \multicolumn{2}{|c|}{ A2 (High) } \\
\hline & & & 2050 & 2100 & 2050 & 2100 & 2050 & 2100 \\
\hline & MS & & 27.7 & 11.4 & 25 & 15.2 & 39.9 & 5.1 \\
\hline \multicolumn{9}{|l|}{ Shrubs } \\
\hline \multirow[t]{4}{*}{ Acacia constricta } & $\mathrm{SH}$ & 3.4 & & & & & & \\
\hline & DS & & 65.2 & 76.4 & 74.2 & 80.1 & 61 & 94 \\
\hline & IS & & 50.6 & 54.8 & 83.5 & 81.7 & 73.5 & 88.5 \\
\hline & MS & & 34.8 & 23.6 & 25.8 & 19.9 & 39 & 6 \\
\hline \multirow[t]{4}{*}{ Acacia greggii } & $\mathrm{SH}$ & 4.4 & & & & & & \\
\hline & DS & & 49.4 & 68.2 & 57.2 & 80.1 & 45.5 & 86.3 \\
\hline & IS & & 91.3 & 95.4 & 119 & 119.9 & 116.5 & 100 \\
\hline & MS & & 50.6 & 31.8 & 42.8 & 19.9 & 54.5 & 13.7 \\
\hline \multirow[t]{4}{*}{$\begin{array}{l}\text { Ambrosia } \\
\text { deltoidea }\end{array}$} & $\mathrm{SH}$ & 1.9 & & & & & & \\
\hline & DS & & 75.6 & 83.7 & 89.8 & 64.8 & 88.3 & 96.5 \\
\hline & IS & & 42.6 & 48.9 & 28.4 & 26.5 & 12.2 & 9.2 \\
\hline & MS & & 24.4 & 16.3 & 10.2 & 35.2 & 11.7 & 3.5 \\
\hline \multirow[t]{4}{*}{ Ambrosia dumosa } & $\mathrm{SH}$ & 7.3 & & & & & & \\
\hline & DS & & 73.2 & 62.8 & 50.5 & 64.5 & 54.1 & 79.8 \\
\hline & IS & & 17.5 & 26.6 & 45.2 & 68.8 & 49.3 & 22 \\
\hline & MS & & 26.8 & 37.2 & 49.5 & 35.5 & 45.9 & 20.2 \\
\hline \multirow[t]{4}{*}{$\begin{array}{l}\text { Amelanchier } \\
\text { alnifolia }\end{array}$} & $\mathrm{SH}$ & 4.6 & & & & & & \\
\hline & DS & & 34.4 & 33.3 & 49.1 & 54.1 & 43.3 & 51.7 \\
\hline & IS & & 58.7 & 75 & 49.6 & 65 & 61.8 & 91.9 \\
\hline & MS & & 65.6 & 66.7 & 50.9 & 45.9 & 56.7 & 48 \\
\hline \multirow[t]{4}{*}{$\begin{array}{l}\text { Amelanchier } \\
\text { utahensis }\end{array}$} & $\mathrm{SH}$ & 7.8 & & & & & & \\
\hline & DS & & 58.7 & 56.9 & 59.6 & 58.3 & 59.4 & 64 \\
\hline & IS & & 36 & 45 & 45.6 & 51.4 & 42.9 & 52.8 \\
\hline & MS & & 41.3 & 43.1 & 40.4 & 41.7 & 40.6 & 36 \\
\hline \multirow[t]{4}{*}{$\begin{array}{l}\text { Arctostaphylos } \\
\text { patula }\end{array}$} & $\mathrm{SH}$ & 2.6 & & & & & & \\
\hline & DS & & 82.3 & 88.1 & 71.1 & 61.5 & 75.5 & 76.1 \\
\hline & IS & & 14.9 & 11.3 & 60.6 & 123.8 & 32.4 & 61.5 \\
\hline & MS & & 17.7 & 11.9 & 28.9 & 38.5 & 24.5 & 23.9 \\
\hline \multirow[t]{4}{*}{$\begin{array}{l}\text { Arctostaphylos } \\
\text { pringlei }\end{array}$} & $\mathrm{SH}$ & 1.2 & & & & & & \\
\hline & DS & & 73.1 & 94.7 & 89.5 & 81.4 & 91.2 & 99.9 \\
\hline & IS & & 32.2 & 18.7 & 30.2 & 85.5 & 17.5 & 9.5 \\
\hline & MS & & 26.9 & 5.3 & 10.5 & 18.6 & 8.8 & 0.1 \\
\hline
\end{tabular}




\begin{tabular}{|c|c|c|c|c|c|c|c|c|}
\hline \multirow[b]{3}{*}{ Species } & \multirow{3}{*}{ 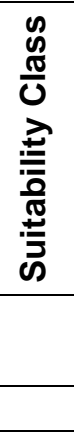 } & \multirow{3}{*}{ 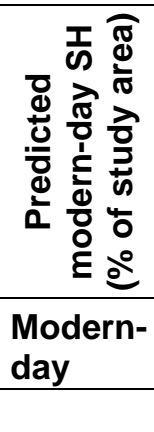 } & \multicolumn{6}{|c|}{$\begin{array}{l}\text { Predicted future SH (\% of modern-day SH } \\
\text { area) by scenario and time-period }\end{array}$} \\
\hline & & & \multicolumn{2}{|c|}{ B1 (Low) } & \multicolumn{2}{|c|}{$\begin{array}{c}\text { A1B } \\
\text { (Medium) }\end{array}$} & \multicolumn{2}{|c|}{ A2 (High) } \\
\hline & & & 2050 & 2100 & 2050 & 2100 & 2050 & 2100 \\
\hline \multirow[t]{4}{*}{$\begin{array}{l}\text { Arctostaphylos } \\
\text { pungens }\end{array}$} & $\mathrm{SH}$ & 2.8 & & & & & & \\
\hline & DS & & 58.6 & 85.9 & 65.4 & 64.8 & 71.7 & 94.7 \\
\hline & IS & & 28.9 & 17.1 & 62 & 69.3 & 22.1 & 16.6 \\
\hline & MS & & 41.4 & 14.1 & 34.6 & 35.2 & 28.3 & 5.3 \\
\hline \multirow[t]{4}{*}{$\begin{array}{l}\text { Arctostaphylos } \\
\text { uva-ursi }\end{array}$} & $\mathrm{SH}$ & 3 & & & & & & \\
\hline & DS & & 54.4 & 70.3 & 74 & 72.6 & 77.4 & 87.7 \\
\hline & IS & & 110.2 & 87.4 & 78.2 & 68.2 & 68.5 & 32 \\
\hline & MS & & 45.6 & 29.7 & 26 & 27.4 & 22.6 & 12.3 \\
\hline \multirow[t]{4}{*}{$\begin{array}{l}\text { Artemisia } \\
\text { arbuscula }\end{array}$} & $\mathrm{SH}$ & 8.3 & & & & & & \\
\hline & DS & & 76.2 & 83.5 & 85 & 94.7 & 86.3 & 97.8 \\
\hline & IS & & 11.5 & 4.6 & 6.9 & 1 & 6.4 & 0.1 \\
\hline & MS & & 23.8 & 16.5 & 15 & 5.3 & 13.7 & 2.2 \\
\hline \multirow[t]{4}{*}{ Artemisia bigelovii } & $\mathrm{SH}$ & 4.5 & & & & & & \\
\hline & DS & & 52 & 68.5 & 70.7 & 84.4 & 59.4 & 85.7 \\
\hline & IS & & 67.4 & 58 & 43.9 & 54.2 & 46.5 & 41 \\
\hline & MS & & 48 & 31.5 & 29.3 & 15.6 & 40.6 & 14.3 \\
\hline \multirow[t]{4}{*}{ Artemisia filifolia } & $\mathrm{SH}$ & 7.6 & 0 & 0 & 0 & 0 & 0 & 0 \\
\hline & DS & & 39.8 & 55.1 & 67.6 & 82.9 & 57.3 & 85.9 \\
\hline & IS & & 134.1 & 143.5 & 116.7 & 133.8 & 101.7 & 146.3 \\
\hline & MS & & 60.2 & 44.9 & 32.4 & 17.1 & 42.7 & 14.1 \\
\hline \multirow[t]{4}{*}{ Artemisia frigida } & $\mathrm{SH}$ & 5.5 & & & & & & \\
\hline & DS & & 49.5 & 56.3 & 62.9 & 56.9 & 65 & 74.7 \\
\hline & IS & & 48.5 & 39.3 & 33.1 & 57.1 & 28.9 & 32.6 \\
\hline & MS & & 50.5 & 43.7 & 37.1 & 43.1 & 35 & 25.3 \\
\hline \multirow[t]{4}{*}{ Artemisia nova } & $\mathrm{SH}$ & 11.5 & & & & & & \\
\hline & DS & & 59.6 & 71.8 & 60.6 & 72 & 55.6 & 80.2 \\
\hline & IS & & 19.7 & 15.7 & 26.4 & 26.1 & 34.8 & 25.9 \\
\hline & MS & & 40.4 & 28.2 & 39.4 & 28 & 44.4 & 19.8 \\
\hline \multirow[t]{4}{*}{$\begin{array}{l}\text { Artemisia } \\
\text { tridentata }\end{array}$} & $\mathrm{SH}$ & 31.5 & & & & & & \\
\hline & DS & & 47.5 & 52.6 & 52.4 & 61.1 & 45.9 & 63.1 \\
\hline & IS & & 7.6 & 6.3 & 9.9 & 6.4 & 11 & 7.3 \\
\hline & MS & & 52.5 & 47.4 & 47.6 & 38.9 & 54.1 & 36.9 \\
\hline \multirow[t]{3}{*}{$\begin{array}{l}\text { Atriplex } \\
\text { canescens }\end{array}$} & $\mathrm{SH}$ & 17 & & & & & & \\
\hline & DS & & 30 & 40.4 & 38.8 & 50.2 & 28.7 & 66.6 \\
\hline & IS & & 64.6 & 65 & 81.4 & 95.4 & 64.3 & 87.5 \\
\hline
\end{tabular}




\begin{tabular}{|c|c|c|c|c|c|c|c|c|}
\hline & 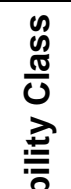 & 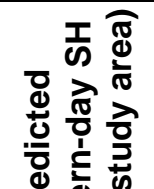 & \multicolumn{6}{|c|}{$\begin{array}{l}\text { Predicted future SH (\% of modern-day SH } \\
\text { area) by scenario and time-period }\end{array}$} \\
\hline & & $\begin{array}{l}\text { Modern- } \\
\text { day }\end{array}$ & B1 ( & ow) & $\begin{array}{r}\mathrm{A} \\
(\mathrm{Mec}\end{array}$ & $\begin{array}{l}\text { B } \\
\text { ium) }\end{array}$ & A2 ( & ligh) \\
\hline \multirow[t]{2}{*}{ Species } & & & 2050 & 2100 & 2050 & 2100 & 2050 & 2100 \\
\hline & MS & & 70 & 59.6 & 61.2 & 49.8 & 71.3 & 33.4 \\
\hline \multirow[t]{4}{*}{$\begin{array}{l}\text { Atriplex } \\
\text { confertifolia }\end{array}$} & $\mathrm{SH}$ & 17.7 & & & & & & \\
\hline & DS & & 39.2 & 49.8 & 52.7 & 61.1 & 50.6 & 70.9 \\
\hline & IS & & 36 & 31 & 26 & 18.3 & 29.8 & 20 \\
\hline & MS & & 60.8 & 50.2 & 47.3 & 38.9 & 49.4 & 29.1 \\
\hline \multirow[t]{4}{*}{ Atriplex corrugata } & $\mathrm{SH}$ & 2.2 & & & & & & \\
\hline & DS & & 79.6 & 78.4 & 83.8 & 83 & 83.3 & 87.9 \\
\hline & IS & & 30.3 & 27.6 & 26.1 & 16.5 & 29.8 & 12 \\
\hline & MS & & 20.4 & 21.6 & 16.2 & 17 & 16.7 & 12.1 \\
\hline \multirow[t]{4}{*}{ Atriplex gardneri } & $\mathrm{SH}$ & 2.8 & & & & & & \\
\hline & DS & & 70.5 & 75.4 & 74.8 & 76.1 & 74.2 & 77.7 \\
\hline & IS & & 25.3 & 20.2 & 31.7 & 25.1 & 17.7 & 17.9 \\
\hline & MS & & 29.5 & 24.6 & 25.2 & 23.9 & 25.8 & 22.3 \\
\hline \multirow[t]{4}{*}{$\begin{array}{l}\text { Atriplex } \\
\text { hymenelytra }\end{array}$} & $\mathrm{SH}$ & 1.6 & & & & & & \\
\hline & DS & & 66 & 73.9 & 86.6 & 91.1 & 82.2 & 97.8 \\
\hline & IS & & 24.7 & 58.4 & 14 & 47.5 & 13.3 & 23.7 \\
\hline & MS & & 34 & 26.1 & 13.4 & 8.9 & 17.8 & 2.2 \\
\hline \multirow[t]{4}{*}{ Atriplex obovata } & $\mathrm{SH}$ & 2.5 & & & & & & \\
\hline & DS & & 19.9 & 38.9 & 36.9 & 67.2 & 24.6 & 43.3 \\
\hline & IS & & 223.7 & 246.9 & 220 & 177.3 & 220.7 & 372.9 \\
\hline & MS & & 80.1 & 61.1 & 63.1 & 32.8 & 75.4 & 56.7 \\
\hline \multirow[t]{4}{*}{ Atriplex polycarpa } & $\mathrm{SH}$ & 4.4 & & & & & & \\
\hline & DS & & 68.5 & 63.3 & 65.2 & 68.8 & 69.6 & 83.2 \\
\hline & IS & & 26.6 & 47.3 & 60.3 & 75.1 & 34.6 & 34.5 \\
\hline & MS & & 31.5 & 36.7 & 34.8 & 31.2 & 30.4 & 16.8 \\
\hline \multirow[t]{4}{*}{$\begin{array}{l}\text { Baccharis } \\
\text { sarothroides }\end{array}$} & $\mathrm{SH}$ & 3 & & & & & & \\
\hline & DS & & 61.8 & 75.4 & 75.3 & 43.8 & 62.6 & 84.2 \\
\hline & IS & & 39.6 & 22.9 & 34.1 & 224.1 & 40.5 & 77.4 \\
\hline & MS & & 38.2 & 24.6 & 24.7 & 56.2 & 37.4 & 15.8 \\
\hline \multirow[t]{4}{*}{$\begin{array}{l}\text { Canotia } \\
\text { holacantha }\end{array}$} & $\mathrm{SH}$ & 1.7 & & & & & & \\
\hline & DS & & 77.8 & 98.9 & 89.9 & 99.1 & 77.9 & 99.7 \\
\hline & IS & & 30.1 & 13.6 & 49.9 & 68 & 56.3 & 56.5 \\
\hline & MS & & 22.2 & 1.1 & 10.1 & 0.9 & 22.1 & 0.3 \\
\hline \multirow[t]{3}{*}{ Ceanothus greggii } & $\mathrm{SH}$ & 2.2 & & & & & & \\
\hline & DS & & 91.7 & 98.6 & 95.3 & 96.4 & 94.6 & 99.7 \\
\hline & IS & & 13 & 3.6 & 9.7 & 18 & 13.7 & 4.4 \\
\hline
\end{tabular}




\begin{tabular}{|c|c|c|c|c|c|c|c|c|}
\hline \multirow[b]{3}{*}{ Species } & \multirow{3}{*}{ 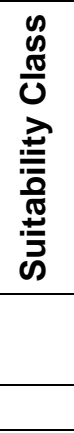 } & \multirow{3}{*}{ 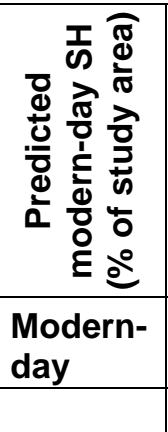 } & \multicolumn{6}{|c|}{$\begin{array}{l}\text { Predicted future SH (\% of modern-day SH } \\
\text { area) by scenario and time-period }\end{array}$} \\
\hline & & & \multicolumn{2}{|c|}{ B1 (Low) } & \multicolumn{2}{|c|}{$\begin{array}{c}\text { A1B } \\
\text { (Medium) }\end{array}$} & \multicolumn{2}{|c|}{ A2 (High) } \\
\hline & & & 2050 & 2100 & 2050 & 2100 & 2050 & 2100 \\
\hline & MS & & 8.3 & 1.4 & 4.7 & 3.6 & 5.4 & 0.3 \\
\hline \multirow[t]{4}{*}{$\begin{array}{l}\text { Cercocarpus } \\
\text { intricatus }\end{array}$} & $\mathrm{SH}$ & 5.6 & & & & & & \\
\hline & DS & & 89.6 & 84.1 & 98.3 & 94.1 & 97 & 98.9 \\
\hline & IS & & 12.2 & 22.1 & 6.9 & 27.5 & 4.5 & 5 \\
\hline & MS & & 10.4 & 15.9 & 1.6 & 5.9 & 3 & 1.1 \\
\hline \multirow[t]{4}{*}{$\begin{array}{l}\text { Cercocarpus } \\
\text { ledifolius }\end{array}$} & $\mathrm{SH}$ & 4.1 & & & & & & \\
\hline & DS & & 77.5 & 87.7 & 78.8 & 87.4 & 76.3 & 90 \\
\hline & IS & & 15.2 & 6.6 & 15.8 & 11.9 & 16.3 & 7.2 \\
\hline & MS & & 22.5 & 12.3 & 21.2 & 12.6 & 23.7 & 10 \\
\hline \multirow[t]{4}{*}{$\begin{array}{l}\text { Cercocarpus } \\
\text { montanus }\end{array}$} & $\mathrm{SH}$ & 9.4 & & & & & & \\
\hline & DS & & 52.5 & 64.1 & 72.7 & 71.6 & 75.6 & 77.3 \\
\hline & IS & & 74.1 & 69.6 & 60.1 & 85.6 & 51.5 & 75.9 \\
\hline & MS & & 47.5 & 35.9 & 27.3 & 28.4 & 24.4 & 22.7 \\
\hline \multirow[t]{4}{*}{$\begin{array}{l}\text { Chrysothamnus } \\
\text { depressus }\end{array}$} & $\mathrm{SH}$ & 4.3 & & & & & & \\
\hline & DS & & 94.4 & 97.1 & 85.7 & 75.7 & 91.9 & 92.8 \\
\hline & IS & & 18.9 & 23.2 & 43.5 & 51.2 & 20.5 & 32.1 \\
\hline & MS & & 5.6 & 2.9 & 14.3 & 24.3 & 8.1 & 7.2 \\
\hline \multirow[t]{4}{*}{$\begin{array}{l}\text { Chrysothamnus } \\
\text { greenei }\end{array}$} & $\mathrm{SH}$ & 7.2 & & & & & & \\
\hline & DS & & 75.7 & 86.3 & 79.3 & 92.8 & 77 & 95.7 \\
\hline & IS & & 42.2 & 50.4 & 55.9 & 56.7 & 28.9 & 32.8 \\
\hline & MS & & 24.3 & 13.7 & 20.7 & 7.2 & 23 & 4.3 \\
\hline \multirow[t]{4}{*}{$\begin{array}{l}\text { Chrysothamnus } \\
\text { viscidiflorus }\end{array}$} & $\mathrm{SH}$ & 15.3 & & & & & & \\
\hline & DS & & 68.8 & 84.2 & 73.9 & 94.6 & 73.3 & 99.1 \\
\hline & IS & & 9 & 4 & 6.9 & 2.2 & 7.8 & 1.4 \\
\hline & MS & & 31.2 & 15.8 & 26.1 & 5.4 & 26.7 & 0.9 \\
\hline \multirow[t]{4}{*}{$\begin{array}{l}\text { Coleogyne } \\
\text { ramosissima }\end{array}$} & $\mathrm{SH}$ & 6.7 & & & & & & \\
\hline & DS & & 57.6 & 73 & 76 & 89.1 & 64.2 & 98.4 \\
\hline & IS & & 71.6 & 81.8 & 92.6 & 94.9 & 77.5 & 59.2 \\
\hline & MS & & 42.4 & 27 & 24 & 10.9 & 35.8 & 1.6 \\
\hline \multirow[t]{3}{*}{ Encelia farinosa } & $\mathrm{SH}$ & 5.6 & & & & & & \\
\hline & DS & & 69.4 & 85.4 & 84.5 & 89.5 & 80.4 & 99 \\
\hline & IS & & 29.7 & 23.6 & 20.2 & 24.7 & 24.1 & 6.3 \\
\hline
\end{tabular}




\begin{tabular}{|c|c|c|c|c|c|c|c|c|}
\hline \multirow[b]{3}{*}{ Species } & \multirow{3}{*}{ 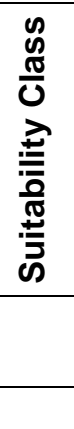 } & \multirow{3}{*}{ 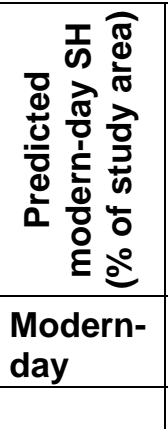 } & \multicolumn{6}{|c|}{$\begin{array}{l}\text { Predicted future } \mathrm{SH} \text { (\% of modern-day } \mathrm{SH} \\
\text { area) by scenario and time-period }\end{array}$} \\
\hline & & & \multicolumn{2}{|c|}{ B1 (Low) } & \multicolumn{2}{|c|}{$\begin{array}{c}\text { A1B } \\
\text { (Medium) }\end{array}$} & \multicolumn{2}{|c|}{ A2 (High) } \\
\hline & & & 2050 & 2100 & 2050 & 2100 & 2050 & 2100 \\
\hline & MS & & 30.6 & 14.6 & 15.5 & 10.5 & 19.6 & 1 \\
\hline \multirow[t]{4}{*}{$\begin{array}{l}\text { Ephedra } \\
\text { nevadensis }\end{array}$} & $\mathrm{SH}$ & 7.9 & & & & & & \\
\hline & DS & & 63.9 & 83 & 66.7 & 55.5 & 46.2 & 72.7 \\
\hline & IS & & 39.9 & 31.9 & 84.5 & 99 & 71.7 & 80.8 \\
\hline & MS & & 36.1 & 17 & 33.3 & 44.5 & 53.8 & 27.3 \\
\hline \multirow[t]{4}{*}{$\begin{array}{l}\text { Ephedra } \\
\text { torreyana }\end{array}$} & $\mathrm{SH}$ & 4 & & & & & & \\
\hline & DS & & 24.7 & 34.6 & 37.6 & 68.5 & 36.3 & 45.7 \\
\hline & IS & & 99.6 & 150.9 & 114.1 & 114.7 & 106.6 & 134.8 \\
\hline & MS & & 75.3 & 65.4 & 62.4 & 31.5 & 63.7 & 54.3 \\
\hline \multirow[t]{4}{*}{ Ephedra trifurca } & $\mathrm{SH}$ & 3.5 & & & & & & \\
\hline & DS & & 39.7 & 32.5 & 49.6 & 68.3 & 26 & 71.3 \\
\hline & IS & & 64 & 101.3 & 90.2 & 73.2 & 148.5 & 189.4 \\
\hline & MS & & 60.3 & 67.5 & 50.4 & 31.7 & 74 & 28.7 \\
\hline \multirow[t]{4}{*}{ Ephedra viridis } & $\mathrm{SH}$ & 13.3 & & & & & & \\
\hline & DS & & 54.9 & 60.4 & 57.2 & 50.1 & 44.9 & 81 \\
\hline & IS & & 25.8 & 35.3 & 47.4 & 70.1 & 36.8 & 34.4 \\
\hline & MS & & 45.1 & 39.6 & 42.8 & 49.9 & 55.1 & 19 \\
\hline \multirow[t]{4}{*}{$\begin{array}{l}\text { Ericameria } \\
\text { linearifolia }\end{array}$} & $\mathrm{SH}$ & 1.1 & & & & & & \\
\hline & DS & & 90.2 & 96.5 & 91.3 & 99.8 & 89.3 & 100 \\
\hline & IS & & 36.7 & 26.5 & 57.8 & 4.2 & 57.7 & 3.8 \\
\hline & MS & & 9.8 & 3.5 & 8.7 & 0.2 & 10.7 & 0 \\
\hline \multirow[t]{4}{*}{$\begin{array}{l}\text { Ericameria } \\
\text { nauseosa }\end{array}$} & $\mathrm{SH}$ & 5.1 & & & & & & \\
\hline & DS & & 70.4 & 79.5 & 82.7 & 84.7 & 80.6 & 88.6 \\
\hline & IS & & 28 & 30.5 & 22.3 & 24.5 & 19.3 & 18.2 \\
\hline & MS & & 29.6 & 20.5 & 17.3 & 15.3 & 19.4 & 11.4 \\
\hline \multirow[t]{4}{*}{$\begin{array}{l}\text { Eriogonum } \\
\text { fasciculatum }\end{array}$} & $\mathrm{SH}$ & 4.4 & & & & & & \\
\hline & DS & & 96.1 & 97.7 & 97.3 & 94 & 81.6 & 99 \\
\hline & IS & & 5.2 & 4 & 7.6 & 47.2 & 53.5 & 8.1 \\
\hline & MS & & 3.9 & 2.3 & 2.7 & 6 & 18.4 & 1 \\
\hline \multirow[t]{4}{*}{$\begin{array}{l}\text { Eriogonum } \\
\text { wrightii }\end{array}$} & $\mathrm{SH}$ & 2.6 & & & & & & \\
\hline & DS & & 87.3 & 97.7 & 86.6 & 44.6 & 41.5 & 82.6 \\
\hline & IS & & 23.6 & 23.8 & 51.2 & 198 & 114.4 & 117.7 \\
\hline & MS & & 12.7 & 2.3 & 13.4 & 55.4 & 58.5 & 17.4 \\
\hline Fallugia paradoxa & $\mathrm{SH}$ & 4 & & & & & & \\
\hline
\end{tabular}




\begin{tabular}{|c|c|c|c|c|c|c|c|c|}
\hline \multirow[b]{3}{*}{ Species } & \multirow{3}{*}{ 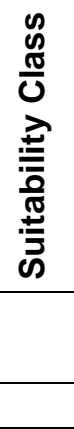 } & \multirow{3}{*}{ 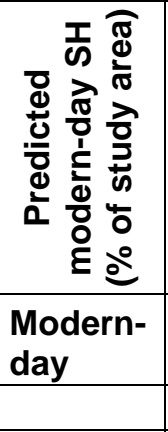 } & \multicolumn{6}{|c|}{$\begin{array}{l}\text { Predicted future SH (\% of modern-day SH } \\
\text { area) by scenario and time-period }\end{array}$} \\
\hline & & & \multicolumn{2}{|c|}{ B1 (Low) } & \multicolumn{2}{|c|}{$\begin{array}{c}\text { A1B } \\
\text { (Medium) }\end{array}$} & \multicolumn{2}{|c|}{ A2 (High) } \\
\hline & & & 2050 & 2100 & 2050 & 2100 & 2050 & 2100 \\
\hline & DS & & 43.7 & 59.9 & 53.9 & 63.5 & 63.4 & 83 \\
\hline & IS & & 90.5 & 73.8 & 100.8 & 99.1 & 27.1 & 66.9 \\
\hline & MS & & 56.3 & 40.1 & 46.1 & 36.5 & 36.6 & 17 \\
\hline \multirow[t]{4}{*}{ Flourensia cernua } & $\mathrm{SH}$ & 1.8 & & & & & & \\
\hline & DS & & 82.3 & 81.9 & 91.4 & 89.1 & 97.8 & 94.3 \\
\hline & IS & & 75.6 & 137.2 & 66.7 & 141.9 & 21.4 & 47.8 \\
\hline & MS & & 17.7 & 18.1 & 8.6 & 10.9 & 2.2 & 5.7 \\
\hline \multirow[t]{4}{*}{$\begin{array}{l}\text { Fouquieria } \\
\text { splendens }\end{array}$} & $\mathrm{SH}$ & 4.3 & & & & & & \\
\hline & DS & & 35.4 & 33.8 & 39.2 & 32.4 & 20.1 & 51.5 \\
\hline & IS & & 80.3 & 145.9 & 126.2 & 145.2 & 152.1 & 167.5 \\
\hline & MS & & 64.6 & 66.2 & 60.8 & 67.6 & 79.9 & 48.5 \\
\hline \multirow[t]{4}{*}{ Garrya flavescens } & $\mathrm{SH}$ & 1.3 & & & & & & \\
\hline & DS & & 98.4 & 97.4 & 87.2 & 69.7 & 86.7 & 97.7 \\
\hline & IS & & 4.8 & 7.1 & 22.8 & 92.9 & 15.1 & 16.1 \\
\hline & MS & & 1.6 & 2.6 & 12.8 & 30.3 & 13.3 & 2.3 \\
\hline \multirow[t]{4}{*}{ Garrya wrightii } & $\mathrm{SH}$ & 1.4 & & & & & & \\
\hline & DS & & 71.8 & 91.8 & 85.7 & 81.7 & 79.4 & 87.3 \\
\hline & IS & & 29.7 & 21.6 & 23.2 & 54 & 26.2 & 50.1 \\
\hline & MS & & 28.2 & 8.2 & 14.3 & 18.3 & 20.6 & 12.7 \\
\hline \multirow[t]{4}{*}{ Grayia spinosa } & $\mathrm{SH}$ & 9 & & & & & & \\
\hline & DS & & 78.4 & 86.2 & 72.9 & 61.2 & 66.1 & 80 \\
\hline & IS & & 20.8 & 16.4 & 52.1 & 71.8 & 58.3 & 24.7 \\
\hline & MS & & 21.6 & 13.8 & 27.1 & 38.8 & 33.9 & 20 \\
\hline \multirow[t]{4}{*}{$\begin{array}{l}\text { Gutierrezia } \\
\text { microcephala }\end{array}$} & $\mathrm{SH}$ & 7.2 & & & & & & \\
\hline & DS & & 71.8 & 79.1 & 77.4 & 75.7 & 70.6 & 84.3 \\
\hline & IS & & 28.4 & 44 & 29.6 & 70.6 & 38.7 & 81 \\
\hline & MS & & 28.2 & 20.9 & 22.6 & 24.3 & 29.4 & 15.7 \\
\hline \multirow[t]{4}{*}{$\begin{array}{l}\text { Gutierrezia } \\
\text { sarothrae }\end{array}$} & $\mathrm{SH}$ & 28.3 & & & & & & \\
\hline & DS & & 40 & 45.6 & 45.1 & 61 & 46.1 & 70.7 \\
\hline & IS & & 27.1 & 30.7 & 36.3 & 41.3 & 26.9 & 37.5 \\
\hline & MS & & 60 & 54.4 & 54.9 & 39 & 53.9 & 29.3 \\
\hline \multirow[t]{4}{*}{$\begin{array}{l}\text { Hymenoclea } \\
\text { salsola }\end{array}$} & $\mathrm{SH}$ & 7.3 & & & & & & \\
\hline & DS & & 86 & 90 & 84.4 & 78.2 & 76.4 & 94.8 \\
\hline & IS & & 17.3 & 13.4 & 34.7 & 87.5 & 50.3 & 46.1 \\
\hline & MS & & 14 & 10 & 15.6 & 21.8 & 23.6 & 5.2 \\
\hline Juniperus & $\mathrm{SH}$ & 5.3 & & & & & & \\
\hline
\end{tabular}




\begin{tabular}{|c|c|c|c|c|c|c|c|c|}
\hline \multirow[b]{3}{*}{ Species } & \multirow{2}{*}{ 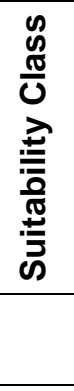 } & \multirow{3}{*}{ 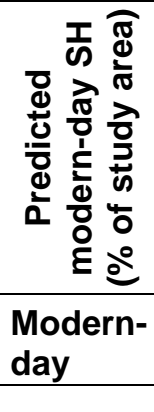 } & \multicolumn{6}{|c|}{$\begin{array}{l}\text { Predicted future SH (\% of modern-day SH } \\
\text { area) by scenario and time-period }\end{array}$} \\
\hline & & & \multicolumn{2}{|c|}{ B1 (Low) } & \multicolumn{2}{|c|}{$\begin{array}{c}\text { A1B } \\
\text { (Medium) }\end{array}$} & \multicolumn{2}{|c|}{ A2 (High) } \\
\hline & & & 2050 & 2100 & 2050 & 2100 & 2050 & 2100 \\
\hline \multicolumn{9}{|l|}{ communis } \\
\hline & DS & & 41.4 & 50.4 & 49.3 & 52.8 & 48 & 79.9 \\
\hline & IS & & 36.5 & 29.7 & 32.8 & 35.5 & 32.6 & 17.1 \\
\hline & MS & & 58.6 & 49.6 & 50.7 & 47.2 & 52 & 20.1 \\
\hline \multirow[t]{4}{*}{$\begin{array}{l}\text { Krascheninnikovia } \\
\text { lanata }\end{array}$} & $\mathrm{SH}$ & 16.4 & & & & & & \\
\hline & DS & & 73 & 82.9 & 67.4 & 62 & 65.1 & 81.4 \\
\hline & IS & & 29.6 & 15.3 & 35.9 & 40.3 & 34.8 & 20 \\
\hline & MS & & 27 & 17.1 & 32.6 & 38 & 34.9 & 18.6 \\
\hline \multirow[t]{4}{*}{ Larrea tridentata } & $\mathrm{SH}$ & 12.9 & & & & & & \\
\hline & DS & & 32.3 & 38.7 & 42.4 & 60.6 & 44.8 & 73.4 \\
\hline & IS & & 72.3 & 96.5 & 110.2 & 146.9 & 84.7 & 124.7 \\
\hline & MS & & 67.7 & 61.3 & 57.6 & 39.4 & 55.2 & 26.6 \\
\hline \multirow[t]{4}{*}{$\begin{array}{l}\text { Lupinus } \\
\text { argenteus }\end{array}$} & $\mathrm{SH}$ & 0.7 & & & & & & \\
\hline & DS & & 56.7 & 82.8 & 70.8 & 96.9 & 46.2 & 98.6 \\
\hline & IS & & 100.5 & 24.3 & 106.7 & 117.3 & 17.1 & 53.6 \\
\hline & MS & & 43.3 & 17.2 & 29.2 & 3.1 & 53.8 & 1.4 \\
\hline \multirow[t]{4}{*}{ Lycium andersonii } & $\mathrm{SH}$ & 2.2 & & & & & & \\
\hline & DS & & 73.7 & 75.1 & 80.3 & 72.7 & 83.4 & 73.1 \\
\hline & IS & & 161.5 & 181.3 & 190.2 & 159.8 & 92.9 & 179.1 \\
\hline & MS & & 26.3 & 24.9 & 19.7 & 27.3 & 16.6 & 26.9 \\
\hline \multirow[t]{4}{*}{ Lycium pallidum } & $\mathrm{SH}$ & 5.6 & & & & & & \\
\hline & DS & & 97.2 & 99.6 & 99.7 & 92.2 & 97.2 & 100 \\
\hline & IS & & 18.5 & 10.2 & 8.4 & 44.8 & 9.4 & 2.7 \\
\hline & MS & & 2.8 & 0.4 & 0.3 & 7.8 & 2.8 & 0 \\
\hline \multirow[t]{4}{*}{ Mahonia repens } & $\mathrm{SH}$ & 6 & & & & & & \\
\hline & DS & & 40 & 51.3 & 51.1 & 58.1 & 54.5 & 67.8 \\
\hline & IS & & 68.8 & 62.9 & 65.1 & 68.1 & 63.8 & 65.5 \\
\hline & MS & & 60 & 48.7 & 48.9 & 41.9 & 45.5 & 32.2 \\
\hline \multirow[t]{4}{*}{$\begin{array}{l}\text { Menodora } \\
\text { spinescens }\end{array}$} & $\mathrm{SH}$ & 2.1 & & & & & & \\
\hline & DS & & 98 & 97.7 & 97.1 & 97.8 & 99.1 & 99.1 \\
\hline & IS & & 59 & 46.9 & 56.1 & 47.7 & 44.1 & 27.7 \\
\hline & MS & & 2 & 2.3 & 2.9 & 2.2 & 0.9 & 0.9 \\
\hline \multirow[t]{3}{*}{$\begin{array}{l}\text { Mimosa } \\
\text { aculeaticarpa }\end{array}$} & $\mathrm{SH}$ & 3.2 & & & & & & \\
\hline & DS & & 63.2 & 81.2 & 81.1 & 80.5 & 64.9 & 89.9 \\
\hline & IS & & 35.7 & 33.3 & 27.8 & 55.9 & 55.8 & 50 \\
\hline
\end{tabular}




\begin{tabular}{|c|c|c|c|c|c|c|c|c|}
\hline & 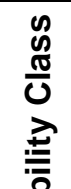 & 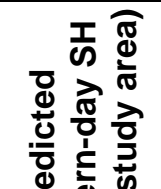 & \multicolumn{6}{|c|}{$\begin{array}{l}\text { Predicted future SH (\% of modern-day SH } \\
\text { area) by scenario and time-period }\end{array}$} \\
\hline & & $\begin{array}{l}\text { Modern- } \\
\text { day }\end{array}$ & \multicolumn{2}{|c|}{ B1 (Low) } & \multicolumn{2}{|c|}{$\begin{array}{c}\text { A1B } \\
\text { (Medium) }\end{array}$} & \multicolumn{2}{|c|}{ A2 (High) } \\
\hline \multirow[t]{2}{*}{ Species } & & & 2050 & 2100 & 2050 & 2100 & 2050 & 2100 \\
\hline & MS & & 36.8 & 18.8 & 18.9 & 19.5 & 35.1 & 10.1 \\
\hline \multirow[t]{4}{*}{ Opuntia basilaris } & $\mathrm{SH}$ & 3.7 & & & & & & \\
\hline & DS & & 87.9 & 86.9 & 93.1 & 93.3 & 94.7 & 99.5 \\
\hline & IS & & 14 & 8.1 & 10.5 & 10.4 & 19.5 & 3.1 \\
\hline & MS & & 12.1 & 13.1 & 6.9 & 6.7 & 5.3 & 0.5 \\
\hline \multirow[t]{4}{*}{$\begin{array}{l}\text { Opuntia } \\
\text { engelmannii }\end{array}$} & $\mathrm{SH}$ & 2.9 & & & & & & \\
\hline & DS & & 69.5 & 80.9 & 74.7 & 85.5 & 63.6 & 84.6 \\
\hline & IS & & 15.8 & 13.7 & 32.6 & 24.8 & 51 & 72.7 \\
\hline & MS & & 30.5 & 19.1 & 25.3 & 14.5 & 36.4 & 15.4 \\
\hline \multirow[t]{4}{*}{$\begin{array}{l}\text { Parthenium } \\
\text { incanum }\end{array}$} & $\mathrm{SH}$ & 2.7 & & & & & & \\
\hline & DS & & 29.4 & 65.4 & 70.7 & 74.7 & 80.6 & 97.7 \\
\hline & IS & & 195.3 & 224.6 & 176.2 & 170.5 & 76 & 38.5 \\
\hline & MS & & 70.6 & 34.6 & 29.3 & 25.3 & 19.4 & 2.3 \\
\hline \multirow[t]{4}{*}{$\begin{array}{l}\text { Paxistima } \\
\text { myrsinites }\end{array}$} & $\mathrm{SH}$ & 2.6 & & & & & & \\
\hline & DS & & 51.9 & 48.8 & 56.8 & 44.9 & 53.7 & 34.6 \\
\hline & IS & & 66.1 & 84.5 & 60.2 & 103.7 & 78.4 & 153.6 \\
\hline & MS & & 48.1 & 51.2 & 43.2 & 55.1 & 46.3 & 65.4 \\
\hline \multirow[t]{4}{*}{$\begin{array}{l}\text { Picrothamnus } \\
\text { desertorum }\end{array}$} & $\mathrm{SH}$ & 6.8 & & & & & & \\
\hline & DS & & 78.8 & 96.1 & 90.5 & 98.4 & 96 & 100 \\
\hline & IS & & 25.8 & 7.6 & 21.8 & 1 & 7.7 & 0 \\
\hline & MS & & 21.2 & 3.9 & 9.5 & 1.6 & 4 & 0 \\
\hline \multirow[t]{4}{*}{$\begin{array}{l}\text { Prunus } \\
\text { fasciculata }\end{array}$} & $\mathrm{SH}$ & 2 & & & & & & \\
\hline & DS & & 85.1 & 94.7 & 85.2 & 91.2 & 77.2 & 100 \\
\hline & IS & & 11.9 & 3.5 & 12.4 & 109.2 & 29.1 & 52.8 \\
\hline & MS & & 14.9 & 5.3 & 14.8 & 8.8 & 22.8 & 0 \\
\hline \multirow[t]{4}{*}{ Prunus virginiana } & $\mathrm{SH}$ & 4.7 & & & & & & \\
\hline & DS & & 40.8 & 48.2 & 54.3 & 60.9 & 43.2 & 61.6 \\
\hline & IS & & 63.6 & 63.8 & 56.7 & 63.6 & 64.4 & 67 \\
\hline & MS & & 59.2 & 51.8 & 45.7 & 39.1 & 56.8 & 38.4 \\
\hline \multirow[t]{4}{*}{ Purshia mexicana } & $\mathrm{SH}$ & 4.4 & & & & & & \\
\hline & DS & & 54.3 & 74.6 & 51.8 & 46.3 & 66.1 & 86.5 \\
\hline & IS & & 37.9 & 35.8 & 96.9 & 129.5 & 28 & 53.6 \\
\hline & MS & & 45.7 & 25.4 & 48.2 & 53.7 & 33.9 & 13.5 \\
\hline $\begin{array}{l}\text { Purshia } \\
\text { stansburiana }\end{array}$ & $\mathrm{SH}$ & 7.8 & & & & & & \\
\hline
\end{tabular}




\begin{tabular}{|c|c|c|c|c|c|c|c|c|}
\hline \multirow[b]{3}{*}{ Species } & \multirow{3}{*}{ 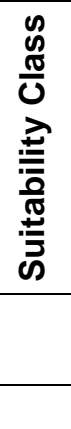 } & \multirow{3}{*}{ 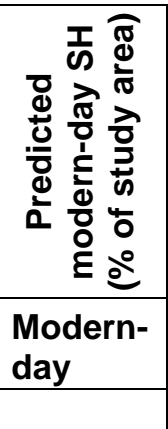 } & \multicolumn{6}{|c|}{$\begin{array}{l}\text { Predicted future } \mathrm{SH} \text { (\% of modern-day } \mathrm{SH} \\
\text { area) by scenario and time-period }\end{array}$} \\
\hline & & & \multicolumn{2}{|c|}{ B1 (Low) } & \multicolumn{2}{|c|}{$\begin{array}{c}\text { A1B } \\
\text { (Medium) }\end{array}$} & \multicolumn{2}{|c|}{ A2 (High) } \\
\hline & & & 2050 & 2100 & 2050 & 2100 & 2050 & 2100 \\
\hline & DS & & 76.3 & 74 & 87.3 & 66.7 & 76.2 & 80.8 \\
\hline & IS & & 37.1 & 48.4 & 45.7 & 87.5 & 35.7 & 72.9 \\
\hline & MS & & 23.7 & 26 & 12.7 & 33.3 & 23.8 & 19.2 \\
\hline \multirow[t]{4}{*}{ Purshia tridentata } & $\mathrm{SH}$ & 11.2 & & & & & & \\
\hline & DS & & 52.9 & 67.3 & 57.7 & 76.6 & 56.6 & 84.3 \\
\hline & IS & & 42.7 & 34.6 & 48.8 & 41.7 & 45.7 & 36.7 \\
\hline & MS & & 47.1 & 32.7 & 42.3 & 23.4 & 43.4 & 15.7 \\
\hline \multirow[t]{4}{*}{ Quercus turbinella } & $\mathrm{SH}$ & 5.3 & & & & & & \\
\hline & DS & & 52.8 & 79.1 & 88.7 & 79.2 & 71.5 & 92.6 \\
\hline & IS & & 41.2 & 34.5 & 23.9 & 43.6 & 36.1 & 35.6 \\
\hline & MS & & 47.2 & 20.9 & 11.3 & 20.8 & 28.5 & 7.4 \\
\hline \multirow[t]{4}{*}{ Rhus microphylla } & $\mathrm{SH}$ & 2.6 & & & & & & \\
\hline & DS & & 55.4 & 63.2 & 82.3 & 72.8 & 91.3 & 96.6 \\
\hline & IS & & 82.3 & 78.9 & 50.9 & 82.7 & 23.6 & 28.5 \\
\hline & MS & & 44.6 & 36.8 & 17.7 & 27.2 & 8.7 & 3.4 \\
\hline \multirow[t]{4}{*}{ Rhus ovata } & $\mathrm{SH}$ & 1 & & & & & & \\
\hline & DS & & 99.2 & 99.4 & 100 & 100 & 99.4 & 100 \\
\hline & IS & & 6.1 & 1.6 & 0.1 & 0.1 & 7 & 0.1 \\
\hline & MS & & 0.8 & 0.6 & 0 & 0 & 0.6 & 0 \\
\hline \multirow[t]{4}{*}{ Rhus trilobata } & $\mathrm{SH}$ & 8.4 & & & & & & \\
\hline & DS & & 53.1 & 76.7 & 83.4 & 64.4 & 73.3 & 80 \\
\hline & IS & & 33 & 25.2 & 25.1 & 52.3 & 26.4 & 37 \\
\hline & MS & & 46.9 & 23.3 & 16.6 & 35.6 & 26.7 & 20 \\
\hline \multirow[t]{4}{*}{ Ribes cereum } & $\mathrm{SH}$ & 5.1 & & & & & & \\
\hline & DS & & 54.7 & 66.5 & 67.6 & 62.7 & 73.4 & 77.9 \\
\hline & IS & & 58.5 & 46.7 & 48.4 & 65.3 & 30.9 & 54 \\
\hline & MS & & 45.3 & 33.5 & 32.4 & 37.3 & 26.6 & 22.1 \\
\hline \multirow[t]{4}{*}{$\begin{array}{l}\text { Ribes } \\
\text { montigenum }\end{array}$} & $\mathrm{SH}$ & 2.3 & & & & & & \\
\hline & DS & & 78.2 & 83.4 & 72.7 & 89.7 & 58.1 & 90.5 \\
\hline & IS & & 22 & 13.3 & 25.5 & 10.3 & 46.6 & 7.8 \\
\hline & MS & & 21.8 & 16.6 & 27.3 & 10.3 & 41.9 & 9.5 \\
\hline \multirow[t]{4}{*}{$\begin{array}{l}\text { Robinia } \\
\text { neomexicana }\end{array}$} & $\mathrm{SH}$ & 1.9 & & & & & & \\
\hline & DS & & 71.1 & 93.8 & 72 & 59.7 & 70.4 & 96.1 \\
\hline & IS & & 13.8 & 10.6 & 21.8 & 43.1 & 23.1 & 24.6 \\
\hline & MS & & 28.9 & 6.2 & 28 & 40.3 & 29.6 & 3.9 \\
\hline \multirow[t]{2}{*}{ Rosa woodsii } & $\mathrm{SH}$ & 9.6 & & & & & & \\
\hline & DS & & 72.4 & 81.2 & 81.2 & 85.2 & 89.6 & 92.7 \\
\hline
\end{tabular}




\begin{tabular}{|c|c|c|c|c|c|c|c|c|}
\hline & 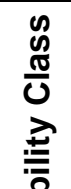 & 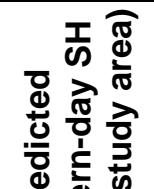 & \multicolumn{6}{|c|}{$\begin{array}{l}\text { Predicted future SH (\% of modern-day SH } \\
\text { area) by scenario and time-period }\end{array}$} \\
\hline & & $\begin{array}{l}\text { Modern- } \\
\text { day }\end{array}$ & B1 ( & $. o w)$ & $\begin{array}{r}\mathrm{A}] \\
(\mathrm{Med}\end{array}$ & $\begin{array}{l}\text { B } \\
\text { ium) }\end{array}$ & A2 ( & ligh) \\
\hline \multirow[t]{3}{*}{ Species } & & & 2050 & 2100 & 2050 & 2100 & 2050 & 2100 \\
\hline & IS & & 37.4 & 27.7 & 29.9 & 26.8 & 15.7 & 17.2 \\
\hline & MS & & 27.6 & 18.8 & 18.8 & 14.8 & 10.4 & 7.3 \\
\hline \multirow[t]{4}{*}{$\begin{array}{l}\text { Salazaria } \\
\text { mexicana }\end{array}$} & $\mathrm{SH}$ & 2.8 & & & & & & \\
\hline & DS & & 92.5 & 92.7 & 91.8 & 92 & 80.3 & 96 \\
\hline & IS & & 11.1 & 11.9 & 20 & 40.9 & 84.5 & 13.6 \\
\hline & MS & & 7.5 & 7.3 & 8.2 & 8 & 19.7 & 4 \\
\hline \multirow[t]{4}{*}{ Salix geyeriana } & $\mathrm{SH}$ & 2.5 & & & & & & \\
\hline & DS & & 44.3 & 46.1 & 84 & 98.2 & 89.9 & 99.2 \\
\hline & IS & & 106.3 & 72.6 & 70.5 & 30.3 & 61.3 & 38.2 \\
\hline & MS & & 55.7 & 53.9 & 16 & 1.8 & 10.1 & 0.8 \\
\hline \multirow[t]{4}{*}{$\begin{array}{l}\text { Sarcobatus } \\
\text { vermiculatus }\end{array}$} & $\mathrm{SH}$ & 14.2 & & & & & & \\
\hline & DS & & 41.9 & 68.7 & 71.1 & 75.9 & 67.7 & 85.3 \\
\hline & IS & & 50.2 & 26.8 & 24.2 & 22.5 & 22.3 & 17.2 \\
\hline & MS & & 58.1 & 31.3 & 28.9 & 24.1 & 32.3 & 14.7 \\
\hline \multirow[t]{4}{*}{$\begin{array}{l}\text { Shepherdia } \\
\text { canadensis }\end{array}$} & $\mathrm{SH}$ & 2.2 & & & & & & \\
\hline & DS & & 16.6 & 25.7 & 22 & 34.1 & 25.9 & 43.6 \\
\hline & IS & & 156.1 & 121.1 & 137.4 & 100.6 & 142.6 & 92.6 \\
\hline & MS & & 83.4 & 74.3 & 78 & 65.9 & 74.1 & 56.4 \\
\hline \multirow[t]{4}{*}{$\begin{array}{l}\text { Simmondsia } \\
\text { chinensis }\end{array}$} & $\mathrm{SH}$ & 1.3 & & & & & & \\
\hline & DS & & 46.6 & 42.8 & 25.7 & 52 & 18.3 & 59.8 \\
\hline & IS & & 87.2 & 266.5 & 202.5 & 233.2 & 410.3 & 193.5 \\
\hline & MS & & 53.4 & 57.2 & 74.3 & 48 & 81.7 & 40.2 \\
\hline \multirow[t]{4}{*}{ Suaeda moquinii } & $\mathrm{SH}$ & 2.1 & & & & & & \\
\hline & DS & & 34.8 & 38.7 & 40.7 & 52.6 & 39.4 & 63.2 \\
\hline & IS & & 176.5 & 164.6 & 114.3 & 102.5 & 153.6 & 111.9 \\
\hline & MS & & 65.2 & 61.3 & 59.3 & 47.4 & 60.6 & 36.8 \\
\hline \multirow[t]{4}{*}{$\begin{array}{l}\text { Symphoricarpos } \\
\text { albus }\end{array}$} & $\mathrm{SH}$ & 3 & & & & & & \\
\hline & DS & & 55.3 & 62.4 & 76.9 & 86.5 & 80.9 & 91.3 \\
\hline & IS & & 84.6 & 74.1 & 52.7 & 67.5 & 43.5 & 50.1 \\
\hline & MS & & 44.7 & 37.6 & 23.1 & 13.5 & 19.1 & 8.7 \\
\hline \multirow[t]{3}{*}{$\begin{array}{l}\text { Symphoricarpos } \\
\text { oreophilus }\end{array}$} & $\mathrm{SH}$ & 6.6 & & & & & & \\
\hline & DS & & 59 & 66.6 & 66 & 80.9 & 67.2 & 84.7 \\
\hline & IS & & 23.2 & 14.5 & 27.1 & 23.1 & 21.6 & 20.5 \\
\hline
\end{tabular}




\begin{tabular}{|c|c|c|c|c|c|c|c|c|}
\hline \multirow[b]{3}{*}{ Species } & \multirow{3}{*}{ 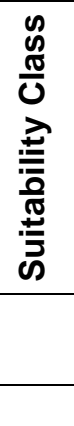 } & \multirow{3}{*}{ 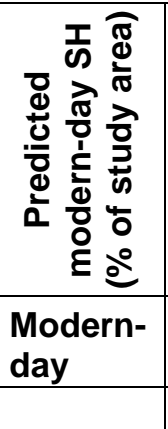 } & \multicolumn{6}{|c|}{$\begin{array}{l}\text { Predicted future } \mathrm{SH} \text { (\% of modern-day } \mathrm{SH} \\
\text { area) by scenario and time-period }\end{array}$} \\
\hline & & & \multicolumn{2}{|c|}{ B1 (Low) } & \multicolumn{2}{|c|}{$\begin{array}{c}\text { A1B } \\
\text { (Medium) }\end{array}$} & \multicolumn{2}{|c|}{ A2 (High) } \\
\hline & & & 2050 & 2100 & 2050 & 2100 & 2050 & 2100 \\
\hline & MS & & 41 & 33.4 & 34 & 19.1 & 32.8 & 15.3 \\
\hline \multirow[t]{4}{*}{$\begin{array}{l}\text { Symphoricarpos } \\
\text { rotundifolius }\end{array}$} & $\mathrm{SH}$ & 2.1 & & & & & & \\
\hline & DS & & 71.6 & 54.6 & 71.9 & 84.2 & 62 & 77.7 \\
\hline & IS & & 58.9 & 109.5 & 76.3 & 67.7 & 102.8 & 103.2 \\
\hline & MS & & 28.4 & 45.4 & 28.1 & 15.8 & 38 & 22.3 \\
\hline \multirow[t]{4}{*}{$\begin{array}{l}\text { Tetradymia } \\
\text { glabrata }\end{array}$} & $\mathrm{SH}$ & 5.9 & & & & & & \\
\hline & DS & & 85.6 & 93.2 & 93.7 & 98.1 & 93.8 & 99.9 \\
\hline & IS & & 40.4 & 53.9 & 52.5 & 33.2 & 39.2 & 3 \\
\hline & MS & & 14.4 & 6.8 & 6.3 & 1.9 & 6.2 & 0.1 \\
\hline \multirow[t]{4}{*}{$\begin{array}{l}\text { Tetradymia } \\
\text { spinosa }\end{array}$} & $\mathrm{SH}$ & 0.9 & & & & & & \\
\hline & DS & & 74.3 & 86.2 & 86.8 & 87.6 & 51.4 & 98.5 \\
\hline & IS & & 10.8 & 12.1 & 19.8 & 10 & 57.5 & 8.2 \\
\hline & MS & & 25.7 & 13.8 & 13.2 & 12.4 & 48.6 & 1.5 \\
\hline \multirow[t]{4}{*}{$\begin{array}{l}\text { Vaccinium } \\
\text { myrtillus }\end{array}$} & $\mathrm{SH}$ & 1.9 & & & & & & \\
\hline & DS & & 55.7 & 62.9 & 74.6 & 81.6 & 63.4 & 90.7 \\
\hline & IS & & 59.7 & 48.7 & 36.4 & 34.8 & 56.6 & 17.1 \\
\hline & MS & & 44.3 & 37.1 & 25.4 & 18.4 & 36.6 & 9.3 \\
\hline \multirow[t]{4}{*}{$\begin{array}{l}\text { Vaccinium } \\
\text { scoparium }\end{array}$} & $\mathrm{SH}$ & 1.1 & & & & & & \\
\hline & DS & & 58.5 & 57.5 & 67.2 & 88.8 & 62 & 88.5 \\
\hline & IS & & 39 & 60.6 & 33.5 & 6.9 & 53.5 & 6.6 \\
\hline & MS & & 41.5 & 42.5 & 32.8 & 11.2 & 38 & 11.5 \\
\hline \multirow[t]{4}{*}{$\begin{array}{l}\text { Yucca } \\
\text { angustissima }\end{array}$} & $\mathrm{SH}$ & 5 & & & & & & \\
\hline & DS & & 45.2 & 65 & 71.2 & 85.4 & 83 & 94.3 \\
\hline & IS & & 64.9 & 76.1 & 43.3 & 41 & 12.4 & 17.9 \\
\hline & MS & & 54.8 & 35 & 28.8 & 14.6 & 17 & 5.7 \\
\hline \multirow[t]{4}{*}{ Yucca baccata } & $\mathrm{SH}$ & 9.4 & & & & & & \\
\hline & DS & & 46.5 & 53.7 & 54.6 & 65.3 & 48.7 & 74 \\
\hline & IS & & 35.1 & 46.4 & 58.2 & 88.1 & 42.8 & 80.6 \\
\hline & MS & & 53.5 & 46.3 & 45.4 & 34.7 & 51.3 & 26 \\
\hline \multirow[t]{4}{*}{ Yucca elata } & $\mathrm{SH}$ & 6 & & & & & & \\
\hline & DS & & 54.9 & 57.3 & 59.6 & 87.6 & 48.2 & 67.4 \\
\hline & IS & & 27 & 38 & 58 & 79.1 & 100.4 & 146.9 \\
\hline & MS & & 45.1 & 42.7 & 40.4 & 12.4 & 51.8 & 32.6 \\
\hline Yucca glauca & $\mathrm{SH}$ & 6.2 & & & & & & \\
\hline
\end{tabular}




\begin{tabular}{|c|c|c|c|c|c|c|c|c|}
\hline \multirow[b]{3}{*}{ Species } & \multirow{3}{*}{ 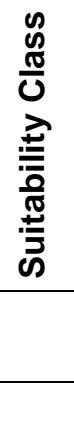 } & \multirow{3}{*}{ 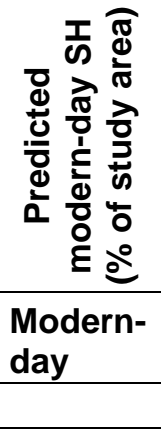 } & \multicolumn{6}{|c|}{$\begin{array}{l}\text { Predicted future SH (\% of modern-day SH } \\
\text { area) by scenario and time-period }\end{array}$} \\
\hline & & & \multicolumn{2}{|c|}{ B1 (Low) } & \multicolumn{2}{|c|}{$\begin{array}{c}\text { A1B } \\
\text { (Medium) }\end{array}$} & \multicolumn{2}{|c|}{ A2 (High) } \\
\hline & & & 2050 & 2100 & 2050 & 2100 & 2050 & 2100 \\
\hline & DS & & 63.7 & 81.7 & 61.7 & 78.7 & 54.3 & 57.8 \\
\hline & IS & & 12.9 & 12.7 & 19.9 & 13.5 & 30.8 & 23.8 \\
\hline & MS & & 36.3 & 18.3 & 38.3 & 21.3 & 45.7 & 42.2 \\
\hline \multirow[t]{4}{*}{ Yucca schidigera } & $\mathrm{SH}$ & 2 & & & & & & \\
\hline & DS & & 99.5 & 100 & 98.9 & 99.6 & 96 & 100 \\
\hline & IS & & 0.1 & 1.7 & 6.2 & 8.8 & 32.8 & 10.3 \\
\hline & MS & & 0.5 & 0 & 1.1 & 0.4 & 4 & 0 \\
\hline \multirow[t]{4}{*}{$\begin{array}{l}\text { Ziziphus } \\
\text { obtusifolia }\end{array}$} & $\mathrm{SH}$ & 1.4 & & & & & & \\
\hline & DS & & 54.8 & 75.6 & 73.9 & 64.5 & 17.1 & 64.3 \\
\hline & IS & & 83.6 & 89.9 & 117.8 & 492.8 & 329.7 & 623 \\
\hline & MS & & 45.2 & 24.4 & 26.1 & 35.5 & 82.9 & 35.7 \\
\hline \multicolumn{9}{|l|}{ Grasses } \\
\hline \multirow[t]{4}{*}{$\begin{array}{l}\text { Achnatherum } \\
\text { hymenoides }\end{array}$} & $\mathrm{SH}$ & 21.6 & & & & & & \\
\hline & DS & & 50.8 & 59.6 & 54.4 & 60 & 45.7 & 72 \\
\hline & IS & & 16.2 & 16.9 & 21.7 & 27.8 & 18.3 & 20.6 \\
\hline & MS & & 49.2 & 40.4 & 45.6 & 40 & 54.3 & 28 \\
\hline \multirow[t]{4}{*}{$\begin{array}{l}\text { Achnatherum } \\
\text { speciosum }\end{array}$} & $\mathrm{SH}$ & 3.3 & & & & & & \\
\hline & DS & & 80.8 & 83.1 & 81.8 & 89.4 & 92.3 & 97.1 \\
\hline & IS & & 14.3 & 13.4 & 18.3 & 2.8 & 7.6 & 2 \\
\hline & MS & & 19.2 & 16.9 & 18.2 & 10.6 & 7.7 & 2.9 \\
\hline \multirow[t]{4}{*}{$\begin{array}{l}\text { Achnatherum } \\
\text { thurberianum }\end{array}$} & $\mathrm{SH}$ & 2.7 & & & & & & \\
\hline & DS & & 71.3 & 92.1 & 88.8 & 100 & 85.1 & 100 \\
\hline & IS & & 15.9 & 6.9 & 12.6 & 3.2 & 7 & 0 \\
\hline & MS & & 28.7 & 7.9 & 11.2 & 0 & 14.9 & 0 \\
\hline \multirow[t]{4}{*}{$\begin{array}{l}\text { Bouteloua } \\
\text { curtipendula }\end{array}$} & $\mathrm{SH}$ & 8.3 & & & & & & \\
\hline & DS & & 62.7 & 73.4 & 71 & 74 & 69.1 & 82 \\
\hline & IS & & 29.3 & 31 & 29.9 & 54.5 & 24 & 49.4 \\
\hline & MS & & 37.3 & 26.6 & 29 & 26 & 30.9 & 18 \\
\hline \multirow[t]{4}{*}{$\begin{array}{l}\text { Bouteloua } \\
\text { eriopoda }\end{array}$} & $\mathrm{SH}$ & 9.8 & & & & & & \\
\hline & DS & & 60.1 & 70.4 & 73.6 & 80.2 & 77 & 93.6 \\
\hline & IS & & 82.8 & 116 & 110.9 & 118.9 & 72.2 & 76.8 \\
\hline & MS & & 39.9 & 29.6 & 26.4 & 19.8 & 23 & 6.4 \\
\hline \multirow[t]{2}{*}{ Bouteloua gracilis } & $\mathrm{SH}$ & 20.4 & & & & & & \\
\hline & DS & & 42 & 56.4 & 61.5 & 65.4 & 59.3 & 78.5 \\
\hline
\end{tabular}




\begin{tabular}{|c|c|c|c|c|c|c|c|c|}
\hline \multirow[b]{3}{*}{ Species } & \multirow{3}{*}{ 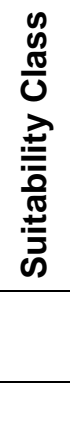 } & \multirow{3}{*}{ 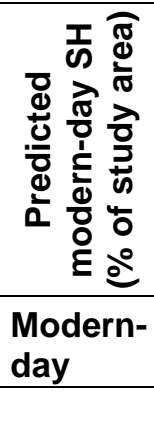 } & \multicolumn{6}{|c|}{$\begin{array}{l}\text { Predicted future SH (\% of modern-day SH } \\
\text { area) by scenario and time-period }\end{array}$} \\
\hline & & & \multicolumn{2}{|c|}{ B1 (Low) } & \multicolumn{2}{|c|}{$\begin{array}{c}\text { A1B } \\
\text { (Medium) }\end{array}$} & \multicolumn{2}{|c|}{ A2 (High) } \\
\hline & & & 2050 & 2100 & 2050 & 2100 & 2050 & 2100 \\
\hline & IS & & 14.9 & 17.4 & 19.1 & 20.2 & 9.8 & 13.5 \\
\hline & MS & & 58 & 43.6 & 38.5 & 34.6 & 40.7 & 21.5 \\
\hline \multirow[t]{4}{*}{ Bouteloua hirsuta } & $\mathrm{SH}$ & 4 & & & & & & \\
\hline & DS & & 69.1 & 70.4 & 77 & 66.1 & 57.8 & 75.2 \\
\hline & IS & & 35.5 & 41.3 & 37 & 62.7 & 61.6 & 125.8 \\
\hline & MS & & 30.9 & 29.6 & 23 & 33.9 & 42.2 & 24.8 \\
\hline \multirow[t]{4}{*}{$\begin{array}{l}\text { Dasyochloa } \\
\text { pulchella }\end{array}$} & $\mathrm{SH}$ & 4.8 & & & & & & \\
\hline & DS & & 46 & 58.5 & 59 & 54.8 & 61.6 & 76.5 \\
\hline & IS & & 179.8 & 242.4 & 279.1 & 284.9 & 172.3 & 178.8 \\
\hline & MS & & 54 & 41.5 & 41 & 45.2 & 38.4 & 23.5 \\
\hline \multirow[t]{4}{*}{ Elymus elymoides } & $\mathrm{SH}$ & 18 & & & & & & \\
\hline & DS & & 69.6 & 70.3 & 77.8 & 80.5 & 76.9 & 91.2 \\
\hline & IS & & 20.3 & 22.6 & 20.2 & 25.9 & 12.7 & 18.5 \\
\hline & MS & & 30.4 & 29.7 & 22.2 & 19.5 & 23.1 & 8.8 \\
\hline \multirow[t]{4}{*}{ Elymus glaucus } & $\mathrm{SH}$ & 1.3 & & & & & & \\
\hline & DS & & 50.8 & 49.4 & 45.9 & 47.6 & 37.6 & 47.3 \\
\hline & IS & & 61.5 & 40.1 & 115.8 & 80.9 & 153.1 & 85.6 \\
\hline & MS & & 49.2 & 50.6 & 54.1 & 52.4 & 62.4 & 52.7 \\
\hline \multirow[t]{4}{*}{$\begin{array}{l}\text { Elymus } \\
\text { trachycaulus }\end{array}$} & $\mathrm{SH}$ & 9.6 & & & & & & \\
\hline & DS & & 43.9 & 52.4 & 46.4 & 57 & 49.9 & 64.5 \\
\hline & IS & & 71.7 & 58.4 & 74.4 & 43.7 & 69.8 & 29.9 \\
\hline & MS & & 56.1 & 47.6 & 53.6 & 43 & 50.1 & 35.5 \\
\hline \multirow[t]{4}{*}{ Festuca arizonica } & $\mathrm{SH}$ & 2 & & & & & & \\
\hline & DS & & 63.3 & 87.8 & 87.5 & 91.4 & 91.3 & 94.2 \\
\hline & IS & & 78.1 & 50.7 & 77.7 & 108.1 & 50.9 & 78.5 \\
\hline & MS & & 36.7 & 12.2 & 12.5 & 8.6 & 8.7 & 5.8 \\
\hline \multirow[t]{4}{*}{$\begin{array}{l}\text { Festuca } \\
\text { brachyphylla }\end{array}$} & $\mathrm{SH}$ & 2.1 & & & & & & \\
\hline & DS & & 57.5 & 68.4 & 71.3 & 96 & 87.1 & 98.5 \\
\hline & IS & & 85.9 & 70.9 & 62.7 & 35.1 & 22.1 & 22.9 \\
\hline & MS & & 42.5 & 31.6 & 28.7 & 4 & 12.9 & 1.5 \\
\hline \multirow[t]{4}{*}{$\begin{array}{l}\text { Festuca } \\
\text { idahoensis }\end{array}$} & $\mathrm{SH}$ & 2.6 & & & & & & \\
\hline & DS & & 61.7 & 62.2 & 74.9 & 82.3 & 67.1 & 75.2 \\
\hline & IS & & 62.3 & 48.1 & 40.4 & 11.4 & 47 & 20.2 \\
\hline & MS & & 38.3 & 37.8 & 25.1 & 17.7 & 32.9 & 24.8 \\
\hline \multirow[t]{2}{*}{ Festuca thurberi } & $\mathrm{SH}$ & 2.3 & & & & & & \\
\hline & DS & & 50.1 & 55.9 & 53.9 & 64.9 & 65.1 & 82.9 \\
\hline
\end{tabular}




\begin{tabular}{|c|c|c|c|c|c|c|c|c|}
\hline \multirow[b]{3}{*}{ Species } & \multirow{3}{*}{ 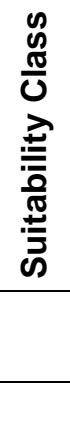 } & \multirow{3}{*}{ 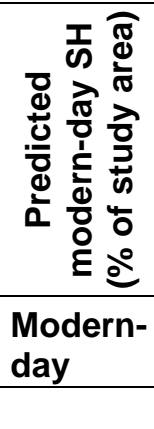 } & \multicolumn{6}{|c|}{$\begin{array}{l}\text { Predicted future SH (\% of modern-day SH } \\
\text { area) by scenario and time-period }\end{array}$} \\
\hline & & & \multicolumn{2}{|c|}{ B1 (Low) } & \multicolumn{2}{|c|}{$\begin{array}{c}\text { A1B } \\
\text { (Medium) }\end{array}$} & \multicolumn{2}{|c|}{ A2 (High) } \\
\hline & & & 2050 & 2100 & 2050 & 2100 & 2050 & 2100 \\
\hline & IS & & 80.2 & 64.2 & 61.7 & 54.4 & 55.8 & 28.5 \\
\hline & MS & & 49.9 & 44.1 & 46.1 & 35.1 & 34.9 & 17.1 \\
\hline \multirow[t]{4}{*}{$\begin{array}{l}\text { Hesperostipa } \\
\text { comata }\end{array}$} & $\mathrm{SH}$ & 14.8 & & & & & & \\
\hline & DS & & 62.5 & 66.8 & 69.1 & 69.9 & 64.5 & 80.3 \\
\hline & IS & & 26.6 & 37.2 & 35.7 & 46.9 & 25.1 & 28 \\
\hline & MS & & 37.5 & 33.2 & 30.9 & 30.1 & 35.5 & 19.7 \\
\hline \multirow[t]{4}{*}{ Hilaria belangeri } & $\mathrm{SH}$ & 1.1 & & & & & & \\
\hline & DS & & 56.6 & 50.6 & 59.3 & 46 & 24.2 & 69.6 \\
\hline & IS & & 53.1 & 81.2 & 97.9 & 158 & 143.1 & 230.8 \\
\hline & MS & & 43.4 & 49.4 & 40.7 & 54 & 75.8 & 30.4 \\
\hline \multirow[t]{4}{*}{ Hordeum jubatum } & $\mathrm{SH}$ & 4.9 & & & & & & \\
\hline & DS & & 59.5 & 72.2 & 65.7 & 72 & 61.6 & 79.5 \\
\hline & IS & & 67.7 & 57.2 & 76.8 & 79.9 & 90.3 & 55.2 \\
\hline & MS & & 40.5 & 27.8 & 34.3 & 28 & 38.4 & 20.5 \\
\hline \multirow[t]{4}{*}{$\begin{array}{l}\text { Koeleria } \\
\text { macrantha }\end{array}$} & $\mathrm{SH}$ & 4.4 & & & & & & \\
\hline & DS & & 56.3 & 64.1 & 68 & 74.1 & 62.4 & 73.7 \\
\hline & IS & & 89 & 102.1 & 86.2 & 103.7 & 82 & 115.3 \\
\hline & MS & & 43.7 & 35.9 & 32 & 25.9 & 37.6 & 26.3 \\
\hline \multirow[t]{4}{*}{ Leymus cinereus } & $\mathrm{SH}$ & 8.1 & & & & & & \\
\hline & DS & & 53.2 & 74.3 & 69.7 & 94.2 & 76.9 & 98.2 \\
\hline & IS & & 19.1 & 5.2 & 8.1 & 0.9 & 5.8 & 0.7 \\
\hline & MS & & 46.8 & 25.7 & 30.3 & 5.8 & 23.1 & 1.8 \\
\hline \multirow[t]{4}{*}{$\begin{array}{l}\text { Muhlenbergia } \\
\text { emersleyi }\end{array}$} & $\mathrm{SH}$ & 1.4 & & & & & & \\
\hline & DS & & 72.1 & 71.9 & 83.4 & 60.1 & 50 & 69 \\
\hline & IS & & 48 & 46.1 & 26.6 & 78.3 & 83 & 73.7 \\
\hline & MS & & 27.9 & 28.1 & 16.6 & 39.9 & 50 & 31 \\
\hline \multirow[t]{4}{*}{$\begin{array}{l}\text { Muhlenbergia } \\
\text { montana }\end{array}$} & $\mathrm{SH}$ & 2.6 & & & & & & \\
\hline & DS & & 69.5 & 82.7 & 82.2 & 86.4 & 83 & 92.2 \\
\hline & IS & & 63.4 & 64.6 & 65.6 & 74 & 54.4 & 80.5 \\
\hline & MS & & 30.5 & 17.3 & 17.8 & 13.6 & 17 & 7.8 \\
\hline \multirow[t]{4}{*}{$\begin{array}{l}\text { Muhlenbergia } \\
\text { porteri }\end{array}$} & $\mathrm{SH}$ & 5.2 & & & & & & \\
\hline & DS & & 34.1 & 32.1 & 54.5 & 32.3 & 40.4 & 60.9 \\
\hline & IS & & 119.4 & 134.8 & 137.3 & 177.8 & 102.2 & 230 \\
\hline & MS & & 65.9 & 67.9 & 45.5 & 67.7 & 59.6 & 39.1 \\
\hline Pascopyrum & $\mathrm{SH}$ & 9.2 & & & & & & \\
\hline
\end{tabular}




\begin{tabular}{|c|c|c|c|c|c|c|c|c|}
\hline \multirow[b]{3}{*}{ Species } & \multirow{2}{*}{ 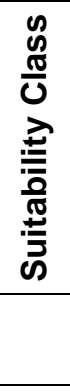 } & \multirow{3}{*}{ 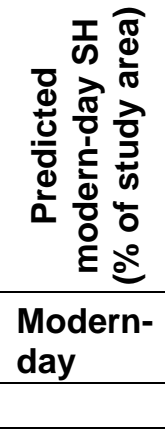 } & \multicolumn{6}{|c|}{$\begin{array}{l}\text { Predicted future } \mathrm{SH} \text { (\% of modern-day } \mathrm{SH} \\
\text { area) by scenario and time-period }\end{array}$} \\
\hline & & & \multicolumn{2}{|c|}{ B1 (Low) } & \multicolumn{2}{|c|}{$\begin{array}{c}\text { A1B } \\
\text { (Medium) }\end{array}$} & \multicolumn{2}{|c|}{ A2 (High) } \\
\hline & & & 2050 & 2100 & 2050 & 2100 & 2050 & 2100 \\
\hline \multicolumn{9}{|l|}{ smithii } \\
\hline & DS & & 57.1 & 63.3 & 64.9 & 73.6 & 57.7 & 79.9 \\
\hline & IS & & 52.8 & 64.3 & 57.6 & 57.5 & 58.3 & 46.2 \\
\hline & MS & & 42.9 & 36.7 & 35.1 & 26.4 & 42.3 & 20.1 \\
\hline \multirow[t]{4}{*}{ Pleuraphis jamesii } & $\mathrm{SH}$ & 16.9 & & & & & & \\
\hline & DS & & 42.7 & 60.9 & 65.9 & 74.8 & 58.5 & 88 \\
\hline & IS & & 29.5 & 35.5 & 36.5 & 40.1 & 27.4 & 23.8 \\
\hline & MS & & 57.3 & 39.1 & 34.1 & 25.2 & 41.5 & 12 \\
\hline \multirow[t]{4}{*}{ Pleuraphis mutica } & $\mathrm{SH}$ & 5 & & & & & & \\
\hline & DS & & 80.4 & 88.9 & 85.5 & 96.6 & 85.5 & 98.3 \\
\hline & IS & & 87.1 & 92.1 & 120.7 & 71.1 & 92.7 & 106.2 \\
\hline & MS & & 19.6 & 11.1 & 14.5 & 3.4 & 14.5 & 1.7 \\
\hline \multirow[t]{4}{*}{ Pleuraphis rigida } & $\mathrm{SH}$ & 4.1 & & & & & & \\
\hline & DS & & 88.2 & 98 & 80.6 & 94.5 & 82.4 & 98.1 \\
\hline & IS & & 39.9 & 19.8 & 78.5 & 68.6 & 74.9 & 33.5 \\
\hline & MS & & 11.8 & 2 & 19.4 & 5.5 & 17.6 & 1.9 \\
\hline \multirow[t]{4}{*}{ Poa fendleriana } & $\mathrm{SH}$ & 6.2 & 0 & 0 & 0 & 0 & 0 & 0 \\
\hline & DS & & 68.2 & 74.6 & 77 & 73.3 & 75.8 & 80.4 \\
\hline & IS & & 52.9 & 75.7 & 70.5 & 110.3 & 49 & 97.1 \\
\hline & MS & & 31.8 & 25.4 & 23 & 26.7 & 24.2 & 19.6 \\
\hline \multirow[t]{4}{*}{ Poa secunda } & $\mathrm{SH}$ & 10.6 & 0 & 0 & 0 & 0 & 0 & 0 \\
\hline & DS & & 26.3 & 34.6 & 35.6 & 56.1 & 47.5 & 71.7 \\
\hline & IS & & 19 & 9.8 & 9.5 & 7.1 & 8.4 & 3.1 \\
\hline & MS & & 73.7 & 65.4 & 64.4 & 43.9 & 52.5 & 28.3 \\
\hline \multirow[t]{4}{*}{$\begin{array}{l}\text { Schizachyrium } \\
\text { scoparium }\end{array}$} & $\mathrm{SH}$ & 6.5 & & & & & & \\
\hline & DS & & 74.6 & 86.8 & 85.2 & 87.3 & 72.1 & 80.7 \\
\hline & IS & & 23.4 & 15.1 & 13.4 & 17.4 & 26.6 & 27.4 \\
\hline & MS & & 25.4 & 13.2 & 14.8 & 12.7 & 27.9 & 19.3 \\
\hline \multirow[t]{4}{*}{$\begin{array}{l}\text { Sporobolus } \\
\text { airoides }\end{array}$} & $\mathrm{SH}$ & 6.8 & & & & & & \\
\hline & DS & & 32.1 & 46.7 & 49.2 & 73.3 & 43 & 83.2 \\
\hline & IS & & 65.1 & 80.1 & 93 & 67.2 & 73.3 & 65.7 \\
\hline & MS & & 67.9 & 53.3 & 50.8 & 26.7 & 57 & 16.8 \\
\hline \multirow[t]{4}{*}{$\begin{array}{l}\text { Sporobolus } \\
\text { cryptandrus }\end{array}$} & $\mathrm{SH}$ & 15.1 & & & & & & \\
\hline & DS & & 69.8 & 82.2 & 87.6 & 95.1 & 76.6 & 97.4 \\
\hline & IS & & 46.8 & 51.1 & 53.6 & 46.7 & 53.7 & 50.8 \\
\hline & MS & & 30.2 & 17.8 & 12.4 & 4.9 & 23.4 & 2.6 \\
\hline
\end{tabular}




\begin{tabular}{|c|c|c|c|c|c|c|c|c|}
\hline & 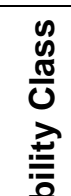 & 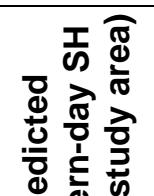 & \multicolumn{6}{|c|}{$\begin{array}{l}\text { Predicted future SH (\% of modern-day SH } \\
\text { area) by scenario and time-period }\end{array}$} \\
\hline & & $\begin{array}{l}\text { Modern- } \\
\text { day }\end{array}$ & \multicolumn{2}{|c|}{ B1 (Low) } & \multicolumn{2}{|c|}{$\begin{array}{c}\text { A1B } \\
\text { (Medium) }\end{array}$} & \multicolumn{2}{|c|}{ A2 (High) } \\
\hline Species & & & 2050 & 2100 & 2050 & 2100 & 2050 & 2100 \\
\hline \multirow[t]{4}{*}{$\begin{array}{l}\text { Sporobolus } \\
\text { flexuosus }\end{array}$} & $\mathrm{SH}$ & 2.9 & & & & & & \\
\hline & DS & & 81.4 & 88.2 & 94.4 & 97.6 & 90.2 & 99.2 \\
\hline & IS & & 98.2 & 111.3 & 70.3 & 40.8 & 119.1 & 34.2 \\
\hline & MS & & 18.6 & 11.8 & 5.6 & 2.4 & 9.8 & 0.8 \\
\hline
\end{tabular}


Table 3. Model agreement for future suitable habitat (SH) predictions for the study plant species $(n=166)$. For each future time period, model agreement was calculated for three suitability classes for SH models based on three future climate models. The area of agreement for where a suitability class was predicted by one, two, or three concurring $\mathrm{SH}$ models was expressed as a proportion of area for each to the total area predicted for the suitability class by all three $\mathrm{SH}$ models. The three suitability classes were (1) DS, decreased suitability; (2) IS, increased suitability; and (3) MS, maintained suitability. The future SH predictions were based on climate models based on 2007 IPPC emission scenarios B1 (global temperature rise of $2.4^{\circ} \mathrm{C}$ ), A1B (global temperature rise of $2.8^{\circ} \mathrm{C}$ ), and A2 (global temperature rise of $3.4^{\circ} \mathrm{C}$ ) for the time period 2050 (2040-2069) and 2100 (2070-2100) as compiled by the Climate Wizard collaboration. 


\begin{tabular}{|c|c|c|c|c|c|c|c|}
\hline \multirow[b]{3}{*}{ Species } & \multirow{3}{*}{ 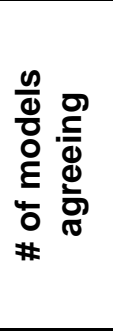 } & \multicolumn{6}{|c|}{$\begin{array}{l}\text { Model agreement for each SH class (\% of total } \\
\text { area predicted for that suitability class) for two } \\
\text { time periods }\end{array}$} \\
\hline & & \multicolumn{3}{|c|}{2050} & \multicolumn{3}{|c|}{2100} \\
\hline & & DS & IS & MS & DS & IS & MS \\
\hline \multicolumn{8}{|l|}{ Trees } \\
\hline \multirow[t]{3}{*}{ Abies concolor } & 1 & 10.0 & 43.1 & 25.8 & 9.1 & 40.2 & 39.5 \\
\hline & 2 & 12.3 & 20.1 & 21.1 & 16.5 & 32.4 & 21.7 \\
\hline & 3 & 77.6 & 36.8 & 53 & 74.5 & 27.4 & 38.8 \\
\hline \multirow[t]{3}{*}{ Abies lasiocarpa } & 1 & 15.8 & 20 & 11.2 & 11.5 & 29.7 & 19.6 \\
\hline & 2 & 12.1 & 23 & 14.6 & 16.9 & 14.8 & 13.3 \\
\hline & 3 & 72 & 57 & 74.2 & 71.6 & 55.6 & 67.1 \\
\hline \multirow[t]{3}{*}{ Acer glabrum } & 1 & 19.6 & 26.7 & 6.4 & 9.2 & 31.5 & 15.5 \\
\hline & 2 & 10.2 & 23.3 & 12.2 & 20.5 & 13.6 & 7 \\
\hline & 3 & 70.1 & 50 & 81.4 & 70.3 & 54.9 & 77.5 \\
\hline \multirow[t]{3}{*}{ Acer grandidentatum } & 1 & 10.1 & 32.4 & 14.4 & 14.4 & 39.3 & 15 \\
\hline & 2 & 13.9 & 26.6 & 10.5 & 14 & 29.2 & 15.4 \\
\hline & 3 & 76 & 41.1 & 75.1 & 71.6 & 31.5 & 69.6 \\
\hline \multirow[t]{3}{*}{ Acer negundo } & 1 & 7.6 & 26.7 & 30.3 & 6 & 32.7 & 30.1 \\
\hline & 2 & 15.9 & 19.2 & 14.5 & 13.4 & 24.7 & 13.5 \\
\hline & 3 & 76.4 & 54.1 & 55.2 & 80.6 & 42.6 & 56.5 \\
\hline \multirow[t]{3}{*}{ Carnegiea gigantea } & 1 & 29.2 & 71.1 & 50.7 & 16.7 & 65.3 & 62.5 \\
\hline & 2 & 47.4 & 21.2 & 31.2 & 49.9 & 21.6 & 21 \\
\hline & 3 & 23.4 & 7.7 & 18.2 & 33.3 & 13.1 & 16.5 \\
\hline \multirow[t]{3}{*}{ Fraxinus velutina } & 1 & 12.3 & 54.6 & 46.5 & 5.6 & 32 & 28 \\
\hline & 2 & 12.4 & 28.6 & 46.3 & 4.2 & 40.7 & 37.3 \\
\hline & 3 & 75.3 & 16.8 & 7.2 & 90.2 & 27.4 & 34.7 \\
\hline \multirow[t]{3}{*}{ Juglans major } & 1 & 5.6 & 59.6 & 57 & 6.3 & 57.2 & 58.6 \\
\hline & 2 & 14.7 & 26.2 & 21.9 & 14.3 & 33 & 25.6 \\
\hline & 3 & 79.7 & 14.2 & 21.1 & 79.4 & 9.8 & 15.9 \\
\hline \multirow[t]{3}{*}{ Juniperus coahuilensis } & 1 & 16.4 & 64 & 53.9 & 14.7 & 68.8 & 29.1 \\
\hline & 2 & 40.7 & 21.4 & 21.7 & 14.8 & 18.4 & 28.8 \\
\hline & 3 & 42.9 & 14.6 & 24.4 & 70.5 & 12.8 & 42 \\
\hline \multirow[t]{3}{*}{ Juniperus deppeana } & 1 & 11.8 & 32.9 & 18.9 & 8.1 & 16 & 14.7 \\
\hline & 2 & 15.4 & 21.9 & 14.6 & 7.8 & 41.9 & 15.1 \\
\hline & 3 & 72.8 & 45.2 & 66.5 & 84.1 & 42.1 & 70.2 \\
\hline \multirow[t]{3}{*}{ Juniperus monosperma } & 1 & 18.5 & 45.7 & 34.1 & 17.6 & 48.2 & 34.8 \\
\hline & 2 & 29.3 & 30.4 & 21.5 & 17.9 & 27.2 & 34.4 \\
\hline & 3 & 52.2 & 23.8 & 44.4 & 64.5 & 24.6 & 30.8 \\
\hline \multirow[t]{3}{*}{ Juniperus osteosperma } & 1 & 16.3 & 32.3 & 16.6 & 22 & 36.8 & 23.3 \\
\hline & 2 & 15.6 & 21.6 & 17.3 & 20.3 & 30.2 & 25.3 \\
\hline & 3 & 68.1 & 46.1 & 66.1 & 57.7 & 32.9 & 51.4 \\
\hline \multirow[t]{3}{*}{ Juniperus scopulorum } & 1 & 10.9 & 36.9 & 34.7 & 11.8 & 32.9 & 31.5 \\
\hline & 2 & 19.2 & 29.1 & 19.6 & 14 & 29.9 & 26.4 \\
\hline & 3 & 69.9 & 34 & 45.8 & 74.2 & 37.2 & 42.1 \\
\hline
\end{tabular}




\begin{tabular}{|c|c|c|c|c|c|c|c|}
\hline \multirow[b]{3}{*}{ Species } & \multirow{3}{*}{ 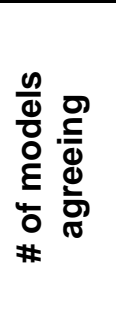 } & \multicolumn{6}{|c|}{$\begin{array}{l}\text { Model agreement for each SH class (\% of total } \\
\text { area predicted for that suitability class) for two } \\
\text { time periods }\end{array}$} \\
\hline & & \multicolumn{3}{|c|}{2050} & \multicolumn{3}{|c|}{2100} \\
\hline & & DS & IS & MS & DS & IS & MS \\
\hline \multirow[t]{3}{*}{ Olneya tesota } & 1 & 34.5 & 56.6 & 28.8 & 34.1 & 57.1 & 24.8 \\
\hline & 2 & 32.9 & 30 & 30.1 & 31 & 30.7 & 27.3 \\
\hline & 3 & 32.6 & 13.4 & 41.1 & 34.9 & 12.2 & 47.9 \\
\hline \multirow[t]{3}{*}{ Parkinsonia florida } & 1 & 23.7 & 40.3 & 59.9 & 13.3 & 59.5 & 63 \\
\hline & 2 & 52.2 & 34.9 & 27.2 & 36.9 & 29.4 & 22.7 \\
\hline & 3 & 24.1 & 24.8 & 12.9 & 49.8 & 11.1 & 14.3 \\
\hline \multirow[t]{3}{*}{ Parkinsonia microphylla } & 1 & 39.1 & 54.6 & 21.1 & 40.7 & 57.7 & 28.7 \\
\hline & 2 & 27.7 & 30.1 & 29.8 & 31.7 & 32.8 & 36.8 \\
\hline & 3 & 33.1 & 15.4 & 49.2 & 27.5 & 9.6 & 34.6 \\
\hline \multirow[t]{3}{*}{ Picea engelmannii } & 1 & 12.6 & 23.1 & 12.6 & 12.9 & 23.7 & 21.6 \\
\hline & 2 & 12.7 & 15.1 & 12.6 & 15.3 & 23.8 & 18.2 \\
\hline & 3 & 74.7 & 61.8 & 74.8 & 71.9 & 52.5 & 60.2 \\
\hline \multirow[t]{3}{*}{ Picea pungens } & 1 & 10.3 & 23.9 & 23.4 & 9.8 & 35.4 & 27.1 \\
\hline & 2 & 14.1 & 17.9 & 17 & 10.4 & 16.1 & 25.6 \\
\hline & 3 & 75.6 & 58.2 & 59.6 & 79.8 & 48.5 & 47.3 \\
\hline \multirow[t]{3}{*}{ Pinus aristata } & 1 & 5.5 & 63.4 & 66.4 & 11 & 50.6 & 44.1 \\
\hline & 2 & 33.3 & 19 & 11 & 10.3 & 32.6 & 47.1 \\
\hline & 3 & 61.2 & 17.7 & 22.6 & 78.7 & 16.9 & 8.9 \\
\hline \multirow[t]{3}{*}{ Pinus contorta } & 1 & 16.7 & 35.1 & 16.6 & 11.8 & 57.9 & 59.5 \\
\hline & 2 & 18.5 & 23 & 15 & 33.1 & 19.5 & 21.3 \\
\hline & 3 & 64.9 & 41.9 & 68.4 & 55.1 & 22.6 & 19.2 \\
\hline \multirow[t]{3}{*}{ Pinus edulis } & 1 & 14.1 & 28.2 & 24.9 & 14.2 & 28.7 & 29.2 \\
\hline & 2 & 20.4 & 21.8 & 17.2 & 16.9 & 25.1 & 24.5 \\
\hline & 3 & 65.5 & 50 & 57.9 & 68.8 & 46.2 & 46.3 \\
\hline \multirow[t]{3}{*}{ Pinus flexilis } & 1 & 3.3 & 54.5 & 56.1 & 1.4 & 60.1 & 78.3 \\
\hline & 2 & 8.2 & 26.9 & 22.9 & 6.1 & 34.7 & 17.7 \\
\hline & 3 & 88.5 & 18.6 & 21.1 & 92.5 & 5.2 & 4 \\
\hline \multirow[t]{3}{*}{ Pinus monophylla } & 1 & 7.4 & 63.2 & 39.7 & 5.9 & 55.9 & 54.1 \\
\hline & 2 & 14.4 & 19.1 & 20.2 & 9.5 & 32.7 & 33.8 \\
\hline & 3 & 78.2 & 17.7 & 40.1 & 84.6 & 11.4 & 12.1 \\
\hline \multirow[t]{3}{*}{ Pinus ponderosa } & 1 & 12.1 & 32.6 & 29.5 & 8.1 & 35.6 & 35.5 \\
\hline & 2 & 14.8 & 26.4 & 24.1 & 10.3 & 29.6 & 27.6 \\
\hline & 3 & 73.1 & 41 & 46.4 & 81.6 & 34.9 & 36.9 \\
\hline \multirow[t]{3}{*}{ Pinus strobiformis } & 1 & 22.9 & 64.9 & 25.1 & 4.2 & 58.3 & 53.5 \\
\hline & 2 & 9.8 & 6.4 & 58.7 & 11.3 & 25 & 19.8 \\
\hline & 3 & 67.3 & 28.6 & 16.2 & 84.5 & 16.7 & 26.7 \\
\hline \multirow[t]{3}{*}{ Populus angustifolia } & 1 & 9 & 31.8 & 33.6 & 9.5 & 32.8 & 47.4 \\
\hline & 2 & 17.2 & 25.7 & 17.6 & 16.1 & 25.6 & 28 \\
\hline & 3 & 73.7 & 42.5 & 48.8 & 74.5 & 41.6 & 24.6 \\
\hline Populus tremuloides & 1 & 10.5 & 19 & 15.4 & 12.6 & 14.6 & 21.7 \\
\hline
\end{tabular}




\begin{tabular}{|c|c|c|c|c|c|c|c|}
\hline \multirow[b]{3}{*}{ Species } & \multirow{3}{*}{ 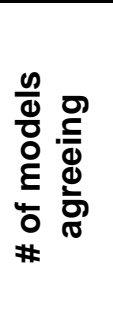 } & \multicolumn{6}{|c|}{$\begin{array}{l}\text { Model agreement for each SH class (\% of total } \\
\text { area predicted for that suitability class) for two } \\
\text { time periods }\end{array}$} \\
\hline & & \multicolumn{3}{|c|}{2050} & \multicolumn{3}{|c|}{2100} \\
\hline & & DS & IS & MS & DS & IS & MS \\
\hline & 2 & 15 & 13.2 & 10.8 & 12.5 & 18.5 & 21.8 \\
\hline & 3 & 74.5 & 67.8 & 73.8 & 74.9 & 66.9 & 56.5 \\
\hline \multirow[t]{3}{*}{ Prosopis glandulosa } & 1 & 46.3 & 43.8 & 20.6 & 42.9 & 37.1 & 33.3 \\
\hline & 2 & 39.1 & 25 & 24.4 & 34.8 & 35.9 & 40.9 \\
\hline & 3 & 14.6 & 31.2 & 55 & 22.3 & 26.9 & 25.8 \\
\hline \multirow[t]{3}{*}{ Prosopis velutina } & 1 & 48.5 & 23 & 13.7 & 44.9 & 23.1 & 11 \\
\hline & 2 & 32.3 & 12.9 & 20.5 & 24.2 & 23 & 20.5 \\
\hline & 3 & 19.1 & 64.1 & 65.9 & 31 & 53.9 & 68.5 \\
\hline \multirow[t]{3}{*}{ Pseudotsuga menziesii } & 1 & 12.2 & 26.2 & 23.6 & 13.2 & 28.2 & 19.5 \\
\hline & 2 & 20.9 & 17.5 & 13.8 & 12.4 & 23.9 & 20.9 \\
\hline & 3 & 66.9 & 56.3 & 62.6 & 74.4 & 47.9 & 59.6 \\
\hline \multirow[t]{3}{*}{ Quercus arizonica } & 1 & 8.5 & 43.2 & 29.2 & 3.7 & 38.7 & 20.1 \\
\hline & 2 & 6.5 & 37.5 & 38 & 4.6 & 17 & 16.4 \\
\hline & 3 & 85 & 19.3 & 32.8 & 91.7 & 44.3 & 63.5 \\
\hline \multirow[t]{3}{*}{ Quercus emoryi } & 1 & 10 & 28.8 & 13.2 & 7.5 & 32.8 & 28.9 \\
\hline & 2 & 6.9 & 35.6 & 19.3 & 10.1 & 33.8 & 21.3 \\
\hline & 3 & 83.1 & 35.6 & 67.5 & 82.4 & 33.3 & 49.8 \\
\hline \multirow[t]{3}{*}{ Quercus gambelii } & 1 & 13.9 & 22.6 & 20.6 & 9.2 & 22.5 & 26.9 \\
\hline & 2 & 18 & 18.8 & 15.9 & 15.7 & 22.5 & 15.7 \\
\hline & 3 & 68.1 & 58.6 & 63.5 & 75.2 & 55 & 57.4 \\
\hline \multirow[t]{3}{*}{ Quercus grisea } & 1 & 8.8 & 47.7 & 61.8 & 6.3 & 46.2 & 44.6 \\
\hline & 2 & 22.7 & 33.9 & 23.9 & 7.9 & 33.7 & 35.9 \\
\hline & 3 & 68.5 & 18.4 & 14.3 & 85.8 & 20.1 & 19.4 \\
\hline \multirow[t]{3}{*}{ Quercus havardii } & 1 & 16.1 & 66.3 & 31.7 & 3.4 & 91.2 & 83.4 \\
\hline & 2 & 14.2 & 25.8 & 36.1 & 27.8 & 5.9 & 10.1 \\
\hline & 3 & 69.8 & 7.9 & 32.3 & 68.8 & 2.9 & 6.5 \\
\hline \multirow[t]{3}{*}{ Yucca brevifolia } & 1 & 13 & 47.4 & 36.8 & 4 & 60.5 & 68.5 \\
\hline & 2 & 20.5 & 26.6 & 23.3 & 15.4 & 28.3 & 17.9 \\
\hline & 3 & 66.5 & 26 & 39.9 & 80.6 & 11.3 & 13.6 \\
\hline \multicolumn{8}{|l|}{ Shrubs } \\
\hline \multirow[t]{3}{*}{ Acacia constricta } & 1 & 13.1 & 44.6 & 37.4 & 9.4 & 49 & 49.9 \\
\hline & 2 & 22.9 & 26.3 & 21.3 & 15.5 & 30.4 & 30.3 \\
\hline & 3 & 64 & 29 & 41.2 & 75.2 & 20.6 & 19.8 \\
\hline \multirow[t]{3}{*}{ Acacia greggii } & 1 & 23.3 & 27.2 & 21 & 10.2 & 33.7 & 48.8 \\
\hline & 2 & 20.3 & 26.8 & 24 & 19.9 & 24.4 & 25 \\
\hline & 3 & 56.4 & 46.1 & 55 & 69.8 & 41.8 & 26.2 \\
\hline \multirow[t]{3}{*}{ Ambrosia deltoidea } & 1 & 4.8 & 49.9 & 61.2 & 5 & 75.4 & 82.5 \\
\hline & 2 & 18.7 & 44.8 & 15.8 & 37.6 & 18.4 & 11 \\
\hline & 3 & 76.4 & 5.3 & 22.9 & 57.5 & 6.2 & 6.6 \\
\hline Ambrosia dumosa & 1 & 25.6 & 54.1 & 30.7 & 13.6 & 63.1 & 46.8 \\
\hline
\end{tabular}




\begin{tabular}{|c|c|c|c|c|c|c|c|}
\hline \multirow[b]{3}{*}{ Species } & \multirow{3}{*}{ 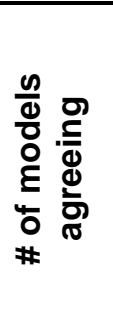 } & \multicolumn{6}{|c|}{$\begin{array}{l}\text { Model agreement for each SH class (\% of total } \\
\text { area predicted for that suitability class) for two } \\
\text { time periods }\end{array}$} \\
\hline & & \multicolumn{3}{|c|}{2050} & \multicolumn{3}{|c|}{2100} \\
\hline & & DS & IS & MS & DS & IS & MS \\
\hline & 2 & 23.3 & 27.5 & 33.8 & 28 & 20.6 & 22.7 \\
\hline & 3 & 51.2 & 18.4 & 35.5 & 58.4 & 16.3 & 30.5 \\
\hline \multirow[t]{3}{*}{ Amelanchier alnifolia } & 1 & 15.8 & 31.5 & 17.8 & 18.4 & 39.5 & 29.6 \\
\hline & 2 & 23.5 & 26.2 & 12 & 34.6 & 21.4 & 15.7 \\
\hline & 3 & 60.7 & 42.2 & 70.3 & 47 & 39.1 & 54.7 \\
\hline \multirow[t]{3}{*}{ Amelanchier utahensis } & 1 & 11.6 & 33.7 & 18.6 & 10.6 & 34.1 & 25 \\
\hline & 2 & 13.6 & 25.4 & 15.8 & 18.6 & 24.6 & 14.3 \\
\hline & 3 & 74.8 & 40.9 & 65.6 & 70.7 & 41.2 & 60.7 \\
\hline \multirow[t]{3}{*}{ Arctostaphylos patula } & 1 & 11.7 & 63.4 & 27.2 & 19.4 & 59.5 & 38.7 \\
\hline & 2 & 10.5 & 25.8 & 30.3 & 17.3 & 33.9 & 43.3 \\
\hline & 3 & 77.9 & 10.8 & 42.4 & 63.3 & 6.6 & 18 \\
\hline \multirow[t]{3}{*}{ Arctostaphylos pringlei } & 1 & 3.4 & 37.8 & 58.9 & 5.3 & 77.1 & 71.4 \\
\hline & 2 & 17.4 & 23.9 & 11.5 & 13.3 & 13.1 & 28.3 \\
\hline & 3 & 79.2 & 38.3 & 29.6 & 81.5 & 9.8 & 0.4 \\
\hline \multirow[t]{3}{*}{ Arctostaphylos pungens } & 1 & 10.7 & 59.8 & 35.5 & 9.6 & 72 & 60.8 \\
\hline & 2 & 22.8 & 17.8 & 16.7 & 22.9 & 12.1 & 25.6 \\
\hline & 3 & 66.5 & 22.4 & 47.9 & 67.5 & 15.8 & 13.6 \\
\hline \multirow[t]{3}{*}{ Arctostaphylos uva-ursi } & 1 & 7.5 & 29.4 & 40.5 & 9.9 & 39.3 & 43.5 \\
\hline & 2 & 23.5 & 13 & 13 & 18.1 & 27.8 & 23.8 \\
\hline & 3 & 68.9 & 57.6 & 46.5 & 71.9 & 33 & 32.7 \\
\hline \multirow[t]{3}{*}{ Artemisia arbuscula } & 1 & 9.6 & 61.7 & 39.1 & 3.8 & 85.6 & 72 \\
\hline & 2 & 11.7 & 25.1 & 31.9 & 13 & 12.8 & 21.1 \\
\hline & 3 & 78.7 & 13.2 & 29 & 83.2 & 1.6 & 6.9 \\
\hline \multirow[t]{3}{*}{ Artemisia bigelovii } & 1 & 20.6 & 54.1 & 25 & 10 & 56.7 & 51.8 \\
\hline & 2 & 17.7 & 23.9 & 29.1 & 20.3 & 26.8 & 25.5 \\
\hline & 3 & 61.7 & 22 & 45.9 & 69.8 & 16.6 & 22.7 \\
\hline \multirow[t]{3}{*}{ Artemisia filifolia } & 1 & 24.2 & 39.7 & 31.4 & 11 & 34 & 56.7 \\
\hline & 2 & 27.6 & 29.3 & 27.6 & 29.1 & 27.8 & 21.4 \\
\hline & 3 & 48.2 & 31 & 41 & 60 & 38.1 & 21.8 \\
\hline \multirow[t]{3}{*}{ Artemisia frigida } & 1 & 10.1 & 47.7 & 28 & 18.4 & 46.9 & 24.8 \\
\hline & 2 & 21.7 & 23.4 & 13.1 & 16.4 & 23.5 & 27.9 \\
\hline & 3 & 68.3 & 28.9 & 58.9 & 65.2 & 29.6 & 47.3 \\
\hline \multirow[t]{3}{*}{ Artemisia nova } & 1 & 11.7 & 47.1 & 25.5 & 14.8 & 44 & 33.9 \\
\hline & 2 & 19.8 & 21.5 & 15.1 & 14.8 & 39.4 & 33.8 \\
\hline & 3 & 68.5 & 31.4 & 59.4 & 70.4 & 16.6 & 32.3 \\
\hline \multirow[t]{3}{*}{ Artemisia tridentata } & 1 & 17.6 & 32.2 & 15.5 & 21 & 35.7 & 35.4 \\
\hline & 2 & 16.2 & 22.8 & 16.8 & 28 & 19.8 & 26.5 \\
\hline & 3 & 66.2 & 45 & 67.6 & 51 & 44.5 & 38 \\
\hline \multirow[t]{2}{*}{ Atriplex canescens } & 1 & 35.1 & 35.5 & 12.2 & 29.6 & 31.4 & 27.8 \\
\hline & 2 & 20.7 & 22.3 & 20.6 & 25.6 & 31.7 & 32.1 \\
\hline
\end{tabular}




\begin{tabular}{|c|c|c|c|c|c|c|c|}
\hline \multirow[b]{3}{*}{ Species } & \multirow{3}{*}{ 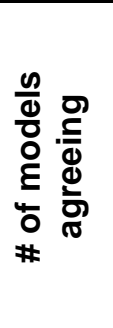 } & \multicolumn{6}{|c|}{$\begin{array}{l}\text { Model agreement for each SH class (\% of total } \\
\text { area predicted for that suitability class) for two } \\
\text { time periods }\end{array}$} \\
\hline & & \multicolumn{3}{|c|}{2050} & \multicolumn{3}{|c|}{2100} \\
\hline & & DS & IS & MS & DS & IS & MS \\
\hline & 3 & 44.2 & 42.2 & 67.2 & 44.9 & 36.9 & 40.1 \\
\hline \multirow[t]{3}{*}{ Atriplex confertifolia } & 1 & 18.9 & 36.3 & 21.7 & 17.4 & 53.7 & 34.2 \\
\hline & 2 & 23.8 & 23.1 & 17.1 & 25.5 & 20.9 & 23.3 \\
\hline & 3 & 57.3 & 40.7 & 61.2 & 57 & 25.3 & 42.5 \\
\hline \multirow[t]{3}{*}{ Atriplex corrugata } & 1 & 5.3 & 27.4 & 29.9 & 5.9 & 45.1 & 26 \\
\hline & 2 & 8.2 & 28.4 & 19.2 & 6.6 & 20.6 & 23.1 \\
\hline & 3 & 86.5 & 44.2 & 50.9 & 87.5 & 34.3 & 50.9 \\
\hline \multirow[t]{3}{*}{ Atriplex gardneri } & 1 & 5.3 & 45.8 & 16.8 & 1.8 & 37.6 & 9.4 \\
\hline & 2 & 6.9 & 30 & 12.9 & 3.1 & 19.9 & 5.4 \\
\hline & 3 & 87.9 & 24.1 & 70.4 & 95.1 & 42.5 & 85.2 \\
\hline \multirow[t]{3}{*}{ Atriplex hymenelytra } & 1 & 7.9 & 66.9 & 48.7 & 7.2 & 57 & 67.7 \\
\hline & 2 & 19.6 & 14.5 & 19.8 & 18.5 & 39.6 & 26.3 \\
\hline & 3 & 72.5 & 18.6 & 31.5 & 74.3 & 3.5 & 6 \\
\hline \multirow[t]{3}{*}{ Atriplex obovata } & 1 & 45.8 & 28.4 & 10.4 & 39.6 & 40.9 & 16.6 \\
\hline & 2 & 20.4 & 19.9 & 23.2 & 15.3 & 28.1 & 42.9 \\
\hline & 3 & 33.8 & 51.7 & 66.4 & 45 & 31 & 40.5 \\
\hline \multirow[t]{3}{*}{ Atriplex polycarpa } & 1 & 14.5 & 59.6 & 28.5 & 17.9 & 55 & 25.1 \\
\hline & 2 & 16 & 27 & 25.9 & 11.8 & 33.3 & 38.1 \\
\hline & 3 & 69.6 & 13.4 & 45.6 & 70.4 & 11.6 & 36.8 \\
\hline \multirow[t]{3}{*}{ Baccharis sarothroides } & 1 & 18.5 & 50 & 23.3 & 14.5 & 68.5 & 57.1 \\
\hline & 2 & 13.2 & 23.8 & 32.5 & 38.4 & 25.4 & 21.5 \\
\hline & 3 & 68.3 & 26.2 & 44.2 & 47.2 & 6.1 & 21.4 \\
\hline \multirow[t]{3}{*}{ Canotia holacantha } & 1 & 8.2 & 59.1 & 57 & 0.2 & 34.8 & 86.9 \\
\hline & 2 & 20.4 & 16.3 & 22.9 & 1.7 & 49.6 & 8.3 \\
\hline & 3 & 71.5 & 24.6 & 20.1 & 98.1 & 15.6 & 4.8 \\
\hline \multirow[t]{3}{*}{ Ceanothus greggii } & 1 & 3.9 & 60.8 & 52.9 & 0.6 & 79.5 & 79.1 \\
\hline & 2 & 6.2 & 22.2 & 33.5 & 3.3 & 11.8 & 14.6 \\
\hline & 3 & 89.9 & 17 & 13.6 & 96.1 & 8.6 & 6.3 \\
\hline \multirow[t]{3}{*}{ Cercocarpus intricatus } & 1 & 1.4 & 82.9 & 82.1 & 2.3 & 83.1 & 81.8 \\
\hline & 2 & 10 & 12.9 & 11.5 & 15.3 & 15.8 & 12.6 \\
\hline & 3 & 88.6 & 4.2 & 6.3 & 82.4 & 1.1 & 5.6 \\
\hline \multirow[t]{3}{*}{ Cercocarpus ledifolius } & 1 & 8.2 & 43.8 & 25.9 & 7.4 & 57.9 & 28.5 \\
\hline & 2 & 9.1 & 21.3 & 23.3 & 5.2 & 28.8 & 40.7 \\
\hline & 3 & 82.6 & 34.9 & 50.9 & 87.4 & 13.2 & 30.8 \\
\hline \multirow[t]{3}{*}{ Cercocarpus montanus } & 1 & 9.3 & 35.4 & 41.4 & 8.3 & 27.3 & 34.4 \\
\hline & 2 & 25.8 & 20.8 & 15 & 17.4 & 26.4 & 16.4 \\
\hline & 3 & 64.9 & 43.8 & 43.6 & 74.3 & 46.3 & 49.2 \\
\hline \multirow[t]{2}{*}{$\begin{array}{l}\text { Chrysothamnus } \\
\text { depressus }\end{array}$} & 1 & 4.9 & 56.1 & 56.4 & 5.6 & 50.1 & 69.8 \\
\hline & 2 & 10.2 & 25.9 & 27.4 & 17.7 & 22.5 & 22.1 \\
\hline
\end{tabular}




\begin{tabular}{|c|c|c|c|c|c|c|c|}
\hline \multirow[b]{3}{*}{ Species } & \multirow{3}{*}{ 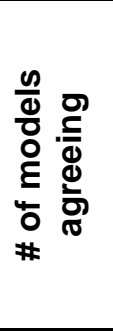 } & \multicolumn{6}{|c|}{$\begin{array}{l}\text { Model agreement for each SH class (\% of total } \\
\text { area predicted for that suitability class) for two } \\
\text { time periods }\end{array}$} \\
\hline & & \multicolumn{3}{|c|}{2050} & \multicolumn{3}{|c|}{2100} \\
\hline & & DS & IS & MS & DS & IS & MS \\
\hline & 3 & 84.9 & 18 & 16.2 & 76.7 & 27.3 & 8.1 \\
\hline \multirow[t]{3}{*}{ Chrysothamnus greenei } & 1 & 4.9 & 46.9 & 30 & 2.9 & 61.9 & 53.7 \\
\hline & 2 & 10.9 & 29.4 & 13.4 & 8.1 & 26.5 & 19.1 \\
\hline & 3 & 84.3 & 23.7 & 56.5 & 89 & 11.6 & 27.2 \\
\hline \multirow[t]{3}{*}{$\begin{array}{l}\text { Chrysothamnus } \\
\text { viscidiflorus }\end{array}$} & 1 & 8.6 & 48.3 & 26.8 & 3.6 & 70.9 & 74.7 \\
\hline & 2 & 12.4 & 24.7 & 18.5 & 12.8 & 22.5 & 21 \\
\hline & 3 & 79 & 27 & 54.6 & 83.6 & 6.6 & 4.3 \\
\hline \multirow[t]{3}{*}{ Coleogyne ramosissima } & 1 & 17.8 & 42.2 & 19.5 & 6.6 & 50.7 & 75.5 \\
\hline & 2 & 11.1 & 21.6 & 31.2 & 23.5 & 31.2 & 21.3 \\
\hline & 3 & 71.1 & 36.1 & 49.3 & 69.8 & 18 & 3.2 \\
\hline \multirow[t]{3}{*}{ Encelia farinosa } & 1 & 10.6 & 48.7 & 39.3 & 6.4 & 72.4 & 61.2 \\
\hline & 2 & 15 & 26.7 & 27.8 & 11.3 & 20.8 & 34.9 \\
\hline & 3 & 74.4 & 24.6 & 32.9 & 82.3 & 6.8 & 4 \\
\hline \multirow[t]{3}{*}{ Ephedra nevadensis } & 1 & 25.1 & 53.9 & 33.4 & 25 & 39.3 & 39 \\
\hline & 2 & 25.9 & 24.8 & 32.3 & 21.3 & 43.1 & 45.8 \\
\hline & 3 & 49 & 21.3 & 34.3 & 53.7 & 17.6 & 15.1 \\
\hline \multirow[t]{3}{*}{ Ephedra torreyana } & 1 & 41.1 & 32 & 12.8 & 37.9 & 38.1 & 22 \\
\hline & 2 & 20.8 & 22.5 & 25.4 & 21 & 36.7 & 39.7 \\
\hline & 3 & 38.2 & 45.6 & 61.8 & 41.1 & 25.2 & 38.3 \\
\hline \multirow[t]{3}{*}{ Ephedra trifurca } & 1 & 41.9 & 42.8 & 24.9 & 30.5 & 58.3 & 49.4 \\
\hline & 2 & 33.4 & 37.6 & 31.3 & 43.2 & 22.5 & 34.9 \\
\hline & 3 & 24.7 & 19.6 & 43.8 & 26.4 & 19.2 & 15.8 \\
\hline \multirow[t]{3}{*}{ Ephedra viridis } & 1 & 22.4 & 40.7 & 21.3 & 22 & 45.6 & 40.9 \\
\hline & 2 & 19.6 & 28.3 & 24.3 & 28.3 & 32.3 & 31.7 \\
\hline & 3 & 58 & 31 & 54.4 & 49.7 & 22.1 & 27.4 \\
\hline \multirow[t]{3}{*}{ Ericameria linearifolia } & 1 & 4.5 & 29.1 & 52.4 & 0.2 & 82 & 94.2 \\
\hline & 2 & 9.3 & 34 & 25.3 & 3.3 & 17.4 & 5.8 \\
\hline & 3 & 86.1 & 36.9 & 22.3 & 96.5 & 0.6 & 0 \\
\hline \multirow[t]{3}{*}{ Ericameria nauseosa } & 1 & 9.1 & 50.2 & 33.6 & 6.3 & 56.1 & 37 \\
\hline & 2 & 12.4 & 22.2 & 24.8 & 9.5 & 22.5 & 24.4 \\
\hline & 3 & 78.5 & 27.6 & 41.5 & 84.2 & 21.5 & 38.6 \\
\hline \multirow[t]{3}{*}{ Eriogonum fasciculatum } & 1 & 2.7 & 84.9 & 74.9 & 1.1 & 83.7 & 75 \\
\hline & 2 & 14 & 9.9 & 14.3 & 5.2 & 14 & 15.5 \\
\hline & 3 & 83.3 & 5.3 & 10.8 & 93.7 & 2.3 & 9.5 \\
\hline \multirow[t]{3}{*}{ Eriogonum wrightii } & 1 & 14.8 & 63.2 & 69.2 & 15.1 & 49.7 & 69.5 \\
\hline & 2 & 44.4 & 24.8 & 23.1 & 39.7 & 40 & 26.4 \\
\hline & 3 & 40.8 & 11.9 & 7.6 & 45.2 & 10.3 & 4.2 \\
\hline \multirow[t]{2}{*}{ Fallugia paradoxa } & 1 & 22.6 & 64.2 & 26.8 & 19.1 & 62.8 & 41 \\
\hline & 2 & 24.1 & 25.1 & 25.1 & 23.9 & 28 & 32.8 \\
\hline
\end{tabular}




\begin{tabular}{|c|c|c|c|c|c|c|c|}
\hline \multirow[b]{3}{*}{ Species } & \multirow{3}{*}{ 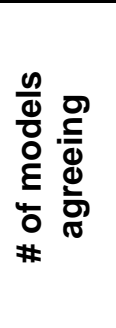 } & \multicolumn{6}{|c|}{$\begin{array}{l}\text { Model agreement for each SH class (\% of total } \\
\text { area predicted for that suitability class) for two } \\
\text { time periods }\end{array}$} \\
\hline & & \multicolumn{3}{|c|}{2050} & \multicolumn{3}{|c|}{2100} \\
\hline & & DS & IS & MS & DS & IS & MS \\
\hline & 3 & 53.3 & 10.7 & 48.2 & 57.1 & 9.2 & 26.3 \\
\hline \multirow[t]{3}{*}{ Flourensia cernua } & 1 & 2.8 & 62.9 & 78.6 & 10.8 & 49.6 & 39.1 \\
\hline & 2 & 17.5 & 25.2 & 12.6 & 8.1 & 40.5 & 51.8 \\
\hline & 3 & 79.7 & 11.8 & 8.8 & 81.1 & 10 & 9.2 \\
\hline \multirow[t]{3}{*}{ Fouquieria splendens } & 1 & 49.4 & 32.8 & 13 & 42.5 & 43.4 & 28.3 \\
\hline & 2 & 21 & 37.5 & 30.7 & 37 & 41.3 & 32.4 \\
\hline & 3 & 29.6 & 29.7 & 56.2 & 20.5 & 15.3 & 39.3 \\
\hline \multirow[t]{3}{*}{ Garrya flavescens } & 1 & 7.1 & 55.9 & 50.9 & 0.3 & 86.2 & 91.4 \\
\hline & 2 & 9 & 25.9 & 39.7 & 28.4 & 7.1 & 1 \\
\hline & 3 & 83.9 & 18.1 & 9.4 & 71.3 & 6.7 & 7.6 \\
\hline \multirow[t]{3}{*}{ Garrya wrightii } & 1 & 7.8 & 29.4 & 39 & 5.2 & 24.4 & 50.1 \\
\hline & 2 & 14 & 25.6 & 21.6 & 11.8 & 40.2 & 22.3 \\
\hline & 3 & 78.2 & 45 & 39.4 & 83 & 35.5 & 27.6 \\
\hline \multirow[t]{3}{*}{ Grayia spinosa } & 1 & 16.8 & 50.5 & 37.1 & 17 & 62.3 & 45 \\
\hline & 2 & 18.2 & 30.7 & 34.2 & 20.4 & 29.4 & 37.4 \\
\hline & 3 & 65 & 18.8 & 28.7 & 62.6 & 8.2 & 17.6 \\
\hline \multirow[t]{3}{*}{$\begin{array}{l}\text { Gutierrezia } \\
\text { microcephala }\end{array}$} & 1 & 19.5 & 52.4 & 37.5 & 14.2 & 48.8 & 40.6 \\
\hline & 2 & 18 & 29.6 & 40.6 & 14.8 & 32.1 & 38.9 \\
\hline & 3 & 62.5 & 18 & 21.9 & 71.1 & 19.1 & 20.5 \\
\hline \multirow[t]{3}{*}{ Gutierrezia sarothrae } & 1 & 14.8 & 35.3 & 12.2 & 14.6 & 36.3 & 31.7 \\
\hline & 2 & 15.2 & 24.5 & 11.9 & 24.8 & 27.5 & 18.7 \\
\hline & 3 & 70 & 40.2 & 75.9 & 60.7 & 36.2 & 49.6 \\
\hline \multirow[t]{3}{*}{ Hymenoclea salsola } & 1 & 7.8 & 64 & 35 & 9 & 50.6 & 57.4 \\
\hline & 2 & 10.2 & 19.8 & 27 & 14.4 & 42.5 & 35.6 \\
\hline & 3 & 82 & 16.2 & 38 & 76.6 & 6.9 & 7 \\
\hline \multirow[t]{3}{*}{ Juniperus communis } & 1 & 14.6 & 27.7 & 18.8 & 31.7 & 28.3 & 18.8 \\
\hline & 2 & 21.8 & 18.1 & 12.6 & 12.5 & 37.2 & 47.6 \\
\hline & 3 & 63.6 & 54.2 & 68.6 & 55.8 & 34.4 & 33.6 \\
\hline \multirow[t]{3}{*}{$\begin{array}{l}\text { Krascheninnikovia } \\
\text { lanata }\end{array}$} & 1 & 15.2 & 45.9 & 34.2 & 18.4 & 56.3 & 41.1 \\
\hline & 2 & 19.2 & 28 & 27.1 & 18.5 & 33.2 & 40.8 \\
\hline & 3 & 65.5 & 26.1 & 38.8 & 63.1 & 10.5 & 18.1 \\
\hline \multirow[t]{3}{*}{ Larrea tridentata } & 1 & 23 & 33.3 & 18.5 & 18.9 & 26.3 & 37.8 \\
\hline & 2 & 25.8 & 23.6 & 16.5 & 31.8 & 34.2 & 22.5 \\
\hline & 3 & 51.2 & 43.2 & 65.1 & 49.2 & 39.5 & 39.7 \\
\hline \multirow[t]{3}{*}{ Lupinus argenteus } & 1 & 26 & 45.7 & 15 & 1.6 & 61.4 & 82.3 \\
\hline & 2 & 11.1 & 49.2 & 35.4 & 14.3 & 36.2 & 9.3 \\
\hline & 3 & 62.9 & 5 & 49.6 & 84 & 2.4 & 8.4 \\
\hline Lycium andersonii & 1 & 9.4 & 47.9 & 48.2 & 17.2 & 42.2 & 43.2 \\
\hline
\end{tabular}




\begin{tabular}{|c|c|c|c|c|c|c|c|}
\hline \multirow[b]{3}{*}{ Species } & \multirow{3}{*}{ 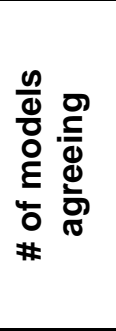 } & \multicolumn{6}{|c|}{$\begin{array}{l}\text { Model agreement for each SH class (\% of total } \\
\text { area predicted for that suitability class) for two } \\
\text { time periods }\end{array}$} \\
\hline & & \multicolumn{3}{|c|}{2050} & \multicolumn{3}{|c|}{2100} \\
\hline & & DS & IS & MS & DS & IS & MS \\
\hline & 2 & 18.6 & 25.8 & 24.4 & 21.2 & 24.1 & 35.1 \\
\hline & 3 & 72 & 26.3 & 27.4 & 61.6 & 33.7 & 21.7 \\
\hline \multirow[t]{3}{*}{ Lycium pallidum } & 1 & 0.1 & 79.9 & 96.8 & 0.2 & 88.5 & 97.3 \\
\hline & 2 & 5.5 & 13.4 & 2.3 & 7.8 & 9.6 & 2.7 \\
\hline & 3 & 94.4 & 6.7 & 0.9 & 92 & 1.9 & 0 \\
\hline \multirow[t]{3}{*}{ Mahonia repens } & 1 & 16.6 & 23.3 & 19.8 & 14.2 & 22.3 & 24.8 \\
\hline & 2 & 21.1 & 20.2 & 15.6 & 18.8 & 23.1 & 18.8 \\
\hline & 3 & 62.3 & 56.5 & 64.6 & 67 & 54.6 & 56.4 \\
\hline \multirow[t]{3}{*}{ Menodora spinescens } & 1 & 1.2 & 49.9 & 60.2 & 0.9 & 69 & 63 \\
\hline & 2 & 2.4 & 31.2 & 31.2 & 2.3 & 23.8 & 25.7 \\
\hline & 3 & 96.4 & 18.9 & 8.6 & 96.7 & 7.1 & 11.3 \\
\hline \multirow[t]{3}{*}{ Mimosa aculeaticarpa } & 1 & 14.4 & 38.8 & 31.2 & 4.9 & 34 & 47.7 \\
\hline & 2 & 16.4 & 27.9 & 27.4 & 13.5 & 34.3 & 17.4 \\
\hline & 3 & 69.2 & 33.3 & 41.4 & 81.5 & 31.7 & 34.9 \\
\hline \multirow[t]{3}{*}{ Opuntia basilaris } & 1 & 4.1 & 66.1 & 62 & 4.7 & 82.1 & 70 \\
\hline & 2 & 10.2 & 25.6 & 25.1 & 10.9 & 16.2 & 30 \\
\hline & 3 & 85.7 & 8.3 & 12.9 & 84.5 & 1.7 & 0 \\
\hline \multirow[t]{3}{*}{ Opuntia engelmannii } & 1 & 8.9 & 62.1 & 26.6 & 11.7 & 74.6 & 27.7 \\
\hline & 2 & 13.8 & 24.7 & 17.1 & 7.3 & 19.1 & 44.6 \\
\hline & 3 & 77.3 & 13.2 & 56.3 & 81 & 6.3 & 27.7 \\
\hline \multirow[t]{3}{*}{ Parthenium incanum } & 1 & 12.6 & 51.8 & 59.9 & 12.3 & 55.7 & 69.9 \\
\hline & 2 & 52.9 & 20.7 & 14.3 & 33 & 31.3 & 26 \\
\hline & 3 & 34.5 & 27.5 & 25.8 & 54.8 & 13 & 4.2 \\
\hline \multirow[t]{3}{*}{ Paxistima myrsinites } & 1 & 13.7 & 33.8 & 18.8 & 20.8 & 37.5 & 13.6 \\
\hline & 2 & 16.5 & 23 & 15.6 & 17.2 & 22.8 & 16.5 \\
\hline & 3 & 69.8 & 43.2 & 65.6 & 62 & 39.8 & 69.9 \\
\hline \multirow[t]{3}{*}{$\begin{array}{l}\text { Picrothamnus } \\
\text { desertorum }\end{array}$} & 1 & 4.8 & 61.7 & 63.8 & 0.2 & 94.6 & 96.4 \\
\hline & 2 & 15.1 & 20.3 & 20.4 & 5.2 & 5.4 & 3.6 \\
\hline & 3 & 80.1 & 18.1 & 15.8 & 94.6 & 0 & 0 \\
\hline \multirow[t]{3}{*}{ Prunus fasciculata } & 1 & 5.9 & 59.1 & 34.7 & 1.8 & 62.2 & 85.3 \\
\hline & 2 & 9.8 & 21.7 & 21 & 10.5 & 37.8 & 14.7 \\
\hline & 3 & 84.3 & 19.2 & 44.2 & 87.7 & 0 & 0 \\
\hline \multirow[t]{3}{*}{ Prunus virginiana } & 1 & 18.8 & 27.2 & 17 & 14.9 & 31.8 & 29.8 \\
\hline & 2 & 19.3 & 26.6 & 16.5 & 24.9 & 24.3 & 17.8 \\
\hline & 3 & 61.9 & 46.2 & 66.5 & 60.3 & 43.9 & 52.4 \\
\hline \multirow[t]{3}{*}{ Purshia mexicana } & 1 & 18.4 & 59.2 & 30.1 & 19.8 & 62.1 & 52.7 \\
\hline & 2 & 24.5 & 27.1 & 22.6 & 32.9 & 23.6 & 31.7 \\
\hline & 3 & 57.1 & 13.7 & 47.3 & 47.4 & 14.3 & 15.6 \\
\hline Purshia stansburiana & 1 & 10.3 & 45.2 & 48.2 & 11.7 & 40.4 & 43.4 \\
\hline
\end{tabular}




\begin{tabular}{|c|c|c|c|c|c|c|c|}
\hline \multirow[b]{3}{*}{ Species } & \multirow{3}{*}{ 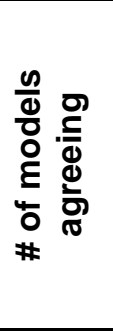 } & \multicolumn{6}{|c|}{$\begin{array}{l}\text { Model agreement for each SH class (\% of total } \\
\text { area predicted for that suitability class) for two } \\
\text { time periods }\end{array}$} \\
\hline & & \multicolumn{3}{|c|}{2050} & \multicolumn{3}{|c|}{2100} \\
\hline & & DS & IS & MS & DS & IS & MS \\
\hline & 2 & 18 & 31.5 & 27.7 & 20.8 & 35.9 & 24.3 \\
\hline & 3 & 71.7 & 23.3 & 24 & 67.5 & 23.7 & 32.4 \\
\hline \multirow[t]{3}{*}{ Purshia tridentata } & 1 & 20.7 & 31.8 & 21.4 & 13.3 & 34.5 & 44.9 \\
\hline & 2 & 17.6 & 24.3 & 25.1 & 19.9 & 30.7 & 30.1 \\
\hline & 3 & 61.6 & 43.9 & 53.5 & 66.8 & 34.8 & 25 \\
\hline \multirow[t]{3}{*}{ Quercus turbinella } & 1 & 16.9 & 33.8 & 51 & 9.4 & 48.6 & 48.4 \\
\hline & 2 & 29.3 & 35.6 & 29.4 & 14.7 & 30.7 & 31 \\
\hline & 3 & 53.8 & 30.6 & 19.6 & 75.9 & 20.8 & 20.6 \\
\hline \multirow[t]{3}{*}{ Rhus microphylla } & 1 & 8.9 & 52.3 & 65.1 & 13.9 & 60.7 & 67.7 \\
\hline & 2 & 33.1 & 24.4 & 17.5 & 34.1 & 27.8 & 27.5 \\
\hline & 3 & 58 & 23.3 & 17.3 & 52 & 11.5 & 4.7 \\
\hline \multirow[t]{3}{*}{ Rhus ovata } & 1 & 0.6 & 41.1 & 17.1 & 0 & 95.4 & 100 \\
\hline & 2 & 0.1 & 58 & 82.9 & 0.6 & 0 & 0 \\
\hline & 3 & 99.2 & 0.9 & 0 & 99.4 & 4.6 & 0 \\
\hline \multirow[t]{3}{*}{ Rhus trilobata } & 1 & 17.5 & 44.7 & 42.9 & 12.9 & 48.9 & 34.3 \\
\hline & 2 & 24.3 & 27 & 31 & 15.6 & 32.4 & 28.3 \\
\hline & 3 & 58.2 & 28.3 & 26.1 & 71.6 & 18.7 & 37.5 \\
\hline \multirow[t]{3}{*}{ Ribes cereum } & 1 & 16 & 42.6 & 34 & 18.9 & 37.6 & 33.8 \\
\hline & 2 & 21.6 & 27.4 & 25.2 & 18.6 & 30.2 & 34.2 \\
\hline & 3 & 62.4 & 30 & 40.8 & 62.5 & 32.3 & 32 \\
\hline \multirow[t]{3}{*}{ Ribes montigenum } & 1 & 11.9 & 45.7 & 34.7 & 4.9 & 46.2 & 46.4 \\
\hline & 2 & 18.7 & 25.6 & 22.1 & 9.8 & 29.4 & 23.3 \\
\hline & 3 & 69.4 & 28.7 & 43.2 & 85.3 & 24.4 & 30.2 \\
\hline \multirow[t]{3}{*}{ Robinia neomexicana } & 1 & 11 & 52.8 & 28.8 & 7.5 & 63.1 & 79.2 \\
\hline & 2 & 14 & 24.9 & 22.6 & 32.6 & 26.7 & 18.1 \\
\hline & 3 & 75 & 22.4 & 48.6 & 59.9 & 10.3 & 2.7 \\
\hline \multirow[t]{3}{*}{ Rosa woodsii } & 1 & 9.7 & 42.3 & 44.9 & 6.6 & 43.9 & 45.5 \\
\hline & 2 & 15.3 & 29.7 & 28.5 & 10.9 & 24.4 & 27.5 \\
\hline & 3 & 75 & 28 & 26.6 & 82.5 & 31.7 & 27 \\
\hline \multirow[t]{3}{*}{ Salazaria mexicana } & 1 & 5.8 & 75.3 & 49.7 & 2.8 & 63.6 & 42.7 \\
\hline & 2 & 10.6 & 16.3 & 27 & 4.5 & 27.1 & 26.3 \\
\hline & 3 & 83.6 & 8.4 & 23.3 & 92.7 & 9.3 & 31 \\
\hline \multirow[t]{3}{*}{ Salix geyeriana } & 1 & 12.2 & 33.1 & 66.5 & 1.8 & 54.5 & 95.9 \\
\hline & 2 & 40 & 16.1 & 20.3 & 51.9 & 7.5 & 3.3 \\
\hline & 3 & 47.8 & 50.9 & 13.2 & 46.3 & 38 & 0.8 \\
\hline \multirow[t]{3}{*}{$\begin{array}{l}\text { Sarcobatus } \\
\text { vermiculatus }\end{array}$} & 1 & 18.6 & 51.1 & 40.4 & 12 & 45.8 & 44.4 \\
\hline & 2 & 31.6 & 24.4 & 23.8 & 19 & 26.8 & 28.1 \\
\hline & 3 & 49.8 & 24.5 & 35.8 & 69 & 27.4 & 27.5 \\
\hline Shepherdia canadensis & 1 & 30.3 & 22.1 & 7.1 & 29.9 & 17.1 & 10 \\
\hline
\end{tabular}




\begin{tabular}{|c|c|c|c|c|c|c|c|}
\hline \multirow[b]{3}{*}{ Species } & \multirow{3}{*}{ 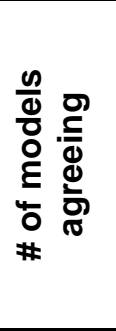 } & \multicolumn{6}{|c|}{$\begin{array}{l}\text { Model agreement for each SH class (\% of total } \\
\text { area predicted for that suitability class) for two } \\
\text { time periods }\end{array}$} \\
\hline & & \multicolumn{3}{|c|}{2050} & \multicolumn{3}{|c|}{2100} \\
\hline & & DS & IS & MS & DS & IS & MS \\
\hline & 2 & 20.7 & 17.3 & 10.4 & 16.2 & 19.2 & 18.4 \\
\hline & 3 & 49 & 60.5 & 82.4 & 53.9 & 63.6 & 71.6 \\
\hline \multirow[t]{3}{*}{ Simmondsia chinensis } & 1 & 40.4 & 61.7 & 14.3 & 18.8 & 55.8 & 35.3 \\
\hline & 2 & 25.6 & 23.8 & 22.5 & 35.7 & 33.9 & 18.5 \\
\hline & 3 & 34 & 14.6 & 63.2 & 45.6 & 10.3 & 46.2 \\
\hline \multirow[t]{3}{*}{ Suaeda moquinii } & 1 & 37.5 & 44.4 & 21 & 28.1 & 52.7 & 31.5 \\
\hline & 2 & 28.7 & 27.3 & 27.4 & 30.5 & 25.8 & 29 \\
\hline & 3 & 33.8 & 28.3 & 51.6 & 41.5 & 21.4 & 39.5 \\
\hline \multirow[t]{3}{*}{ Symphoricarpos albus } & 1 & 8.7 & 44 & 48.3 & 6.4 & 47.7 & 64.5 \\
\hline & 2 & 26.8 & 24.2 & 15.6 & 26.8 & 29.2 & 15.3 \\
\hline & 3 & 64.5 & 31.8 & 36.1 & 66.8 & 23.1 & 20.2 \\
\hline \multirow[t]{3}{*}{$\begin{array}{l}\text { Symphoricarpos } \\
\text { oreophilus } \\
\end{array}$} & 1 & 15.5 & 35.5 & 18.6 & 11.9 & 53.4 & 56.9 \\
\hline & 2 & 11.3 & 34.7 & 25.5 & 25.9 & 32.1 & 26.2 \\
\hline & 3 & 73.2 & 29.8 & 56 & 62.1 & 14.5 & 16.9 \\
\hline \multirow[t]{3}{*}{$\begin{array}{l}\text { Symphoricarpos } \\
\text { rotundifolius }\end{array}$} & 1 & 10.4 & 39.2 & 38.1 & 10.1 & 43.9 & 51.7 \\
\hline & 2 & 21.9 & 24.8 & 18.1 & 28.2 & 29.2 & 18.5 \\
\hline & 3 & 67.6 & 36 & 43.7 & 61.8 & 26.9 & 29.8 \\
\hline \multirow[t]{3}{*}{ Tetradymia glabrata } & 1 & 3.9 & 49.8 & 65 & 1.4 & 81 & 80.4 \\
\hline & 2 & 12.1 & 29.6 & 21.2 & 5.9 & 18.4 & 19.4 \\
\hline & 3 & 84 & 20.6 & 13.8 & 92.7 & 0.5 & 0.2 \\
\hline \multirow[t]{3}{*}{ Tetradymia spinosa } & 1 & 23 & 64.8 & 38.4 & 0.3 & 66.5 & 92.9 \\
\hline & 2 & 20.5 & 20.5 & 43.1 & 23 & 10.7 & 1 \\
\hline & 3 & 56.5 & 14.8 & 18.5 & 76.7 & 22.7 & 6.1 \\
\hline \multirow[t]{3}{*}{ Vaccinium myrtillus } & 1 & 16.1 & 22.7 & 21 & 10.3 & 38 & 51.5 \\
\hline & 2 & 12.7 & 29.2 & 26.5 & 21.3 & 33 & 24.9 \\
\hline & 3 & 71.2 & 48.1 & 52.5 & 68.5 & 29 & 23.7 \\
\hline \multirow[t]{3}{*}{ Vaccinium scoparium } & 1 & 12.7 & 46.4 & 18.6 & 5.9 & 85.4 & 66.9 \\
\hline & 2 & 12 & 25.8 & 19.7 & 31.1 & 6.8 & 12.7 \\
\hline & 3 & 75.2 & 27.8 & 61.7 & 63 & 7.8 & 20.4 \\
\hline \multirow[t]{3}{*}{ Yucca angustissima } & 1 & 14.1 & 57.4 & 50.8 & 10.8 & 74.2 & 59 \\
\hline & 2 & 34.3 & 29.4 & 20.9 & 22.2 & 20 & 28.6 \\
\hline & 3 & 51.6 & 13.2 & 28.3 & 67 & 5.7 & 12.4 \\
\hline \multirow[t]{3}{*}{ Yucca baccata } & 1 & 15.8 & 50 & 21.6 & 11.4 & 51.9 & 45.9 \\
\hline & 2 & 22.1 & 23.3 & 15.4 & 32.5 & 25.8 & 16.1 \\
\hline & 3 & 62.1 & 26.7 & 63 & 56.2 & 22.4 & 38 \\
\hline \multirow[t]{3}{*}{ Yucca elata } & 1 & 24 & 54.3 & 23.5 & 19.7 & 58.4 & 56.7 \\
\hline & 2 & 20.3 & 29.3 & 27.6 & 34.3 & 30.9 & 32.6 \\
\hline & 3 & 55.7 & 16.4 & 48.9 & 45.9 & 10.8 & 10.8 \\
\hline
\end{tabular}




\begin{tabular}{|c|c|c|c|c|c|c|c|}
\hline \multirow[b]{3}{*}{ Species } & \multirow{3}{*}{ 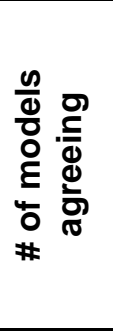 } & \multicolumn{6}{|c|}{$\begin{array}{l}\text { Model agreement for each SH class (\% of total } \\
\text { area predicted for that suitability class) for two } \\
\text { time periods }\end{array}$} \\
\hline & & \multicolumn{3}{|c|}{2050} & \multicolumn{3}{|c|}{2100} \\
\hline & & DS & IS & MS & DS & IS & MS \\
\hline \multirow[t]{3}{*}{ Yucca glauca } & 1 & 17.1 & 44.6 & 26.3 & 15.9 & 69.1 & 58 \\
\hline & 2 & 19.3 & 41.2 & 23.2 & 32.8 & 19.8 & 28.2 \\
\hline & 3 & 63.6 & 14.2 & 50.6 & 51.3 & 11 & 13.8 \\
\hline \multirow[t]{3}{*}{ Yucca schidigera } & 1 & 1.2 & 88.9 & 74.2 & 0 & 90.6 & 100 \\
\hline & 2 & 3.3 & 11.1 & 25.8 & 0.4 & 3.1 & 0 \\
\hline & 3 & 95.5 & 0 & 0 & 99.6 & 6.3 & 0 \\
\hline \multirow[t]{3}{*}{ Ziziphus obtusifolia } & 1 & 28 & 61.7 & 44.4 & 12.8 & 37.3 & 8.5 \\
\hline & 2 & 49.2 & 15.9 & 25.3 & 4.2 & 49.7 & 25.9 \\
\hline & 3 & 22.8 & 22.4 & 30.3 & 83.1 & 13 & 65.6 \\
\hline \multicolumn{8}{|l|}{ Grasses } \\
\hline \multirow[t]{3}{*}{$\begin{array}{l}\text { Achnatherum } \\
\text { hymenoides }\end{array}$} & 1 & 21.3 & 40.6 & 22.1 & 18 & 41.3 & 28.2 \\
\hline & 2 & 21.9 & 29.8 & 21.5 & 18.2 & 31.7 & 27.9 \\
\hline & 3 & 56.8 & 29.6 & 56.5 & 63.9 & 26.9 & 43.9 \\
\hline \multirow[t]{3}{*}{$\begin{array}{l}\text { Achnatherum } \\
\text { speciosum }\end{array}$} & 1 & 8.2 & 60.2 & 36.5 & 9.9 & 81.7 & 33.8 \\
\hline & 2 & 9.1 & 32.9 & 33 & 5.9 & 16.6 & 56.5 \\
\hline & 3 & 82.6 & 6.9 & 30.5 & 84.2 & 1.7 & 9.7 \\
\hline \multirow[t]{3}{*}{$\begin{array}{l}\text { Achnatherum } \\
\text { thurberianum }\end{array}$} & 1 & 7.8 & 43.7 & 44.2 & 0 & 74.6 & 100 \\
\hline & 2 & 14.2 & 30.6 & 24.1 & 7.9 & 25.4 & 0 \\
\hline & 3 & 78 & 25.7 & 31.7 & 92.1 & 0 & 0 \\
\hline \multirow[t]{3}{*}{ Bouteloua curtipendula } & 1 & 9.3 & 34.1 & 21.2 & 10.1 & 41.7 & 23.9 \\
\hline & 2 & 11.4 & 22 & 17.3 & 8.9 & 30 & 27.3 \\
\hline & 3 & 79.3 & 43.9 & 61.5 & 81 & 28.3 & 48.8 \\
\hline \multirow[t]{3}{*}{ Bouteloua eriopoda } & 1 & 11.5 & 40.7 & 38.9 & 13.6 & 30.5 & 42.4 \\
\hline & 2 & 21 & 27.5 & 21.3 & 14.3 & 35.4 & 40.5 \\
\hline & 3 & 67.5 & 31.8 & 39.8 & 72.1 & 34.1 & 17.1 \\
\hline \multirow[t]{3}{*}{ Bouteloua gracilis } & 1 & 25 & 43.5 & 25.2 & 20.9 & 38.4 & 31 \\
\hline & 2 & 21.9 & 29 & 28.7 & 18.3 & 37.4 & 35.5 \\
\hline & 3 & 53.1 & 27.5 & 46.1 & 60.8 & 24.3 & 33.5 \\
\hline \multirow[t]{3}{*}{ Bouteloua hirsuta } & 1 & 12.6 & 58.1 & 30.3 & 13.8 & 64.7 & 30.6 \\
\hline & 2 & 17 & 22.9 & 22.6 & 15.5 & 18.8 & 27.3 \\
\hline & 3 & 70.4 & 18.9 & 47.2 & 70.7 & 16.5 & 42.1 \\
\hline \multirow[t]{3}{*}{ Dasyochloa pulchella } & 1 & 21.6 & 56.3 & 46.2 & 17.1 & 48.2 & 41.1 \\
\hline & 2 & 43 & 24.2 & 23.3 & 29.2 & 24.5 & 24.2 \\
\hline & 3 & 35.4 & 19.5 & 30.5 & 53.7 & 27.2 & 34.7 \\
\hline \multirow[t]{3}{*}{ Elymus elymoides } & 1 & 12.3 & 51 & 37.4 & 10.8 & 49.2 & 53.8 \\
\hline & 2 & 16.6 & 29.9 & 27.7 & 20.3 & 33.2 & 28.5 \\
\hline & 3 & 71.2 & 19.1 & 34.9 & 68.9 & 17.6 & 17.7 \\
\hline
\end{tabular}




\begin{tabular}{|c|c|c|c|c|c|c|c|}
\hline \multirow[b]{3}{*}{ Species } & \multirow{3}{*}{ 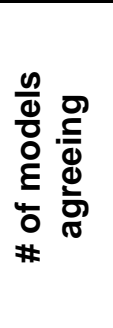 } & \multicolumn{6}{|c|}{$\begin{array}{l}\text { Model agreement for each SH class (\% of total } \\
\text { area predicted for that suitability class) for two } \\
\text { time periods }\end{array}$} \\
\hline & & \multicolumn{3}{|c|}{2050} & \multicolumn{3}{|c|}{2100} \\
\hline & & DS & IS & MS & DS & IS & MS \\
\hline \multirow[t]{3}{*}{ Elymus glaucus } & 1 & 15.6 & 43.7 & 14 & 24.3 & 46.2 & 20.2 \\
\hline & 2 & 16.8 & 24.8 & 13 & 21.3 & 27 & 23.1 \\
\hline & 3 & 67.6 & 31.5 & 73 & 54.4 & 26.7 & 56.6 \\
\hline \multirow[t]{3}{*}{ Elymus trachycaulus } & 1 & 18.9 & 40.2 & 19.3 & 16.2 & 52.7 & 25.6 \\
\hline & 2 & 21.7 & 26.7 & 16.9 & 20.1 & 26.5 & 20.6 \\
\hline & 3 & 59.4 & 33.1 & 63.8 & 63.6 & 20.8 & 53.8 \\
\hline \multirow[t]{3}{*}{ Festuca arizonica } & 1 & 9.2 & 45.5 & 64.1 & 5.1 & 35.5 & 43.4 \\
\hline & 2 & 26.2 & 22.1 & 22.5 & 6.7 & 39.2 & 33.3 \\
\hline & 3 & 64.6 & 32.4 & 13.4 & 88.2 & 25.3 & 23.3 \\
\hline \multirow[t]{3}{*}{ Festuca brachyphylla } & 1 & 20 & 47.9 & 34 & 3.5 & 68.7 & 88.5 \\
\hline & 2 & 16.8 & 34.9 & 40.4 & 29.4 & 22.2 & 10.5 \\
\hline & 3 & 63.2 & 17.2 & 25.6 & 67.1 & 9.2 & 0.9 \\
\hline \multirow[t]{3}{*}{ Festuca idahoensis } & 1 & 11.3 & 59.9 & 34.3 & 8.3 & 78.2 & 51 \\
\hline & 2 & 19.7 & 20.2 & 19.6 & 26.3 & 12.1 & 16 \\
\hline & 3 & 69 & 20 & 46.1 & 65.4 & 9.7 & 33 \\
\hline \multirow[t]{3}{*}{ Festuca thurberi } & 1 & 20.1 & 33 & 20.7 & 20.7 & 34.3 & 27.4 \\
\hline & 2 & 16.7 & 19.8 & 24.9 & 15.2 & 30 & 37.3 \\
\hline & 3 & 63.2 & 47.1 & 54.4 & 64.1 & 35.7 & 35.2 \\
\hline \multirow[t]{3}{*}{ Hesperostipa comata } & 1 & 18.3 & 46.2 & 24.3 & 13.7 & 44.1 & 32.2 \\
\hline & 2 & 14.5 & 28.6 & 30.6 & 15.3 & 31.6 & 28.9 \\
\hline & 3 & 67.2 & 25.2 & 45.1 & 70.9 & 24.3 & 38.9 \\
\hline \multirow[t]{3}{*}{ Hilaria belangeri } & 1 & 24.3 & 39.5 & 33.9 & 26.2 & 58.6 & 14.3 \\
\hline & 2 & 39 & 29.3 & 21.1 & 11.4 & 18.5 & 32.9 \\
\hline & 3 & 36.7 & 31.2 & 44.9 & 62.3 & 22.9 & 52.8 \\
\hline \multirow[t]{3}{*}{ Hordeum jubatum } & 1 & 9.9 & 33.6 & 26.7 & 8.5 & 39.9 & 33.8 \\
\hline & 2 & 18.2 & 27.2 & 14.4 & 14.6 & 31.7 & 19.7 \\
\hline & 3 & 71.9 & 39.2 & 58.9 & 77 & 28.4 & 46.5 \\
\hline \multirow[t]{3}{*}{ Koeleria macrantha } & 1 & 15.4 & 37.8 & 23.6 & 8.9 & 33.1 & 31.1 \\
\hline & 2 & 15.8 & 25 & 23.1 & 15.6 & 28.4 & 17.8 \\
\hline & 3 & 68.8 & 37.2 & 53.3 & 75.4 & 38.5 & 51.2 \\
\hline \multirow[t]{3}{*}{ Leymus cinereus } & 1 & 12.9 & 61.1 & 37.7 & 3.7 & 83 & 79 \\
\hline & 2 & 23.3 & 23 & 21 & 20.9 & 11.1 & 14.1 \\
\hline & 3 & 63.8 & 15.9 & 41.3 & 75.4 & 5.9 & 6.9 \\
\hline \multirow[t]{3}{*}{ Muhlenbergia emersleyi } & 1 & 14.1 & 41.8 & 43.7 & 5.4 & 44.5 & 22.5 \\
\hline & 2 & 26.1 & 33.6 & 23.6 & 12.5 & 13.7 & 9.8 \\
\hline & 3 & 59.8 & 24.5 & 32.7 & 82.1 & 41.8 & 67.7 \\
\hline \multirow[t]{3}{*}{ Muhlenbergia montana } & 1 & 5.1 & 55.9 & 44.7 & 8.4 & 46 & 31.6 \\
\hline & 2 & 17.2 & 19.1 & 13.2 & 6.6 & 32.9 & 40.5 \\
\hline & 3 & 77.7 & 25 & 42 & 85 & 21.1 & 27.9 \\
\hline Muhlenbergia porteri & 1 & 40 & 53.6 & 26.2 & 50.9 & 53.3 & 19.3 \\
\hline
\end{tabular}




\begin{tabular}{|c|c|c|c|c|c|c|c|}
\hline \multirow[b]{3}{*}{ Species } & \multirow{3}{*}{ 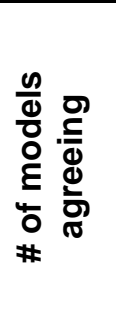 } & \multicolumn{6}{|c|}{$\begin{array}{l}\text { Model agreement for each SH class (\% of total } \\
\text { area predicted for that suitability class) for two } \\
\text { time periods }\end{array}$} \\
\hline & & \multicolumn{3}{|c|}{2050} & \multicolumn{3}{|c|}{2100} \\
\hline & & DS & IS & MS & DS & IS & MS \\
\hline & 2 & 30.8 & 23.3 & 34 & 21.9 & 24.8 & 44.8 \\
\hline & 3 & 29.2 & 23.1 & 39.7 & 27.2 & 22 & 35.9 \\
\hline \multirow[t]{3}{*}{ Pascopyrum smithii } & 1 & 18.5 & 33.2 & 21.2 & 11.1 & 39.8 & 36.3 \\
\hline & 2 & 15.1 & 29.6 & 25.9 & 17.7 & 27.2 & 22.8 \\
\hline & 3 & 66.3 & 37.2 & 52.9 & 71.2 & 33 & 40.9 \\
\hline \multirow[t]{3}{*}{ Pleuraphis jamesii } & 1 & 19.6 & 39.4 & 30.4 & 14.3 & 42.9 & 41.9 \\
\hline & 2 & 26.2 & 26.8 & 22.7 & 19.5 & 26.5 & 30.8 \\
\hline & 3 & 54.2 & 33.7 & 46.9 & 66.3 & 30.6 & 27.3 \\
\hline \multirow[t]{3}{*}{ Pleuraphis mutica } & 1 & 5.9 & 42.7 & 39.3 & 3.2 & 52.5 & 65.6 \\
\hline & 2 & 10.6 & 24.5 & 22.1 & 7.6 & 35.8 & 27.8 \\
\hline & 3 & 83.5 & 32.8 & 38.6 & 89.2 & 11.7 & 6.6 \\
\hline \multirow[t]{3}{*}{ Pleuraphis rigida } & 1 & 10.5 & 48.6 & 44.5 & 1.1 & 64.4 & 73.5 \\
\hline & 2 & 13.1 & 31.7 & 35.5 & 5.1 & 20.9 & 16.4 \\
\hline & 3 & 76.5 & 19.7 & 20 & 93.8 & 14.7 & 10.1 \\
\hline \multirow[t]{3}{*}{ Poa fendleriana } & 1 & 8.8 & 32.7 & 32.8 & 7.4 & 24.8 & 30.7 \\
\hline & 2 & 14.6 & 26.1 & 19.7 & 12 & 28.3 & 19 \\
\hline & 3 & 76.6 & 41.3 & 47.5 & 80.6 & 46.9 & 50.3 \\
\hline \multirow[t]{3}{*}{ Poa secunda } & 1 & 34.3 & 58.4 & 17.4 & 30.6 & 69 & 38.7 \\
\hline & 2 & 25.8 & 21.7 & 23.2 & 35.3 & 20 & 33.6 \\
\hline & 3 & 40 & 19.9 & 59.4 & 34 & 11 & 27.7 \\
\hline \multirow[t]{3}{*}{$\begin{array}{l}\text { Schizachyrium } \\
\text { scoparium }\end{array}$} & 1 & 11.4 & 42.6 & 35 & 7.2 & 59.1 & 61.4 \\
\hline & 2 & 13.5 & 34.3 & 29.4 & 19 & 27.3 & 23.4 \\
\hline & 3 & 75.1 & 23.1 & 35.6 & 73.8 & 13.7 & 15.1 \\
\hline \multirow[t]{3}{*}{ Sporobolus airoides } & 1 & 33 & 39.1 & 20.9 & 14 & 41 & 51.8 \\
\hline & 2 & 26.4 & 24.8 & 26.1 & 33.6 & 24 & 21.5 \\
\hline & 3 & 40.6 & 36 & 53.1 & 52.4 & 34.9 & 26.6 \\
\hline \multirow[t]{3}{*}{ Sporobolus cryptandrus } & 1 & 14.9 & 33.9 & 31.3 & 3.5 & 47.4 & 74.2 \\
\hline & 2 & 11.6 & 28.7 & 40.2 & 14.3 & 26.3 & 17.9 \\
\hline & 3 & 73.5 & 37.4 & 28.5 & 82.3 & 26.3 & 7.9 \\
\hline \multirow[t]{3}{*}{ Sporobolus flexuosus } & 1 & 3.8 & 51.6 & 54.8 & 1.6 & 72.6 & 80.1 \\
\hline & 2 & 11.5 & 29.2 & 18.4 & 9.6 & 21.7 & 13.4 \\
\hline & 3 & 84.7 & 19.1 & 26.8 & 88.8 & 5.8 & 6.5 \\
\hline
\end{tabular}


Table 4. Suitable habitat (SH) vulnerability and potential scores for each of the study plant species $(n=166)$ for two time periods. The vulnerability score represents the SH area, averaged over three future $\mathrm{SH}$ models, scenarios, predicted to decrease in the future divided by area predicted as suitable habitat for the species in modern-day. The higher the score, the more SH predicted to be lost and the higher the species' predicted vulnerability. The potential score is the $\mathrm{SH}$, averaged over three future SH models, predicted to be gained in the future divided by the area predicted as $\mathrm{SH}$ for the species in modern-day. The higher the potential score, the more $\mathrm{SH}$ is predicted to be gained during the future time period. A score greater than 1 indicates the species is predicted to have more $\mathrm{SH}$ in the future than was predicted for the modern day. The future SH predictions were based on climate models based on 2007 IPPC emission scenarios $\mathrm{B} 1$ (global temperature rise of $2.4^{\circ} \mathrm{C}$ ), A1B (global temperature rise of $2.8^{\circ} \mathrm{C}$ ), and A2 (global temperature rise of $3.4^{\circ} \mathrm{C}$ ) for the time period $2050(2040-2069)$ and 2100 (2070-2100) as compiled by the Climate Wizard collaboration. 


\begin{tabular}{|c|c|c|c|c|}
\hline \multirow{2}{*}{$\begin{array}{l}\text { Species } \\
\text { Time Period }\end{array}$} & \multicolumn{2}{|c|}{$\begin{array}{l}\text { Vulnerability } \\
\text { score }\end{array}$} & \multicolumn{2}{|c|}{ Potential score } \\
\hline & 2050 & 2100 & 2050 & 2100 \\
\hline \multicolumn{5}{|l|}{ Trees } \\
\hline Abies concolor & 0.712 & 0.761 & 0.232 & 0.297 \\
\hline Abies lasiocarpa & 0.473 & 0.549 & 0.317 & 0.24 \\
\hline Acer glabrum & 0.362 & 0.43 & 1.548 & 1.87 \\
\hline Acer grandidentatum & 0.514 & 0.52 & 0.945 & 1.371 \\
\hline Acer negundo & 0.694 & 0.731 & 1.247 & 1.673 \\
\hline Carnegiea gigantea & 0.553 & 0.638 & 0.577 & 0.51 \\
\hline Fraxinus velutina & 0.86 & 0.901 & 0.383 & 0.519 \\
\hline Juglans major & 0.866 & 0.876 & 0.255 & 0.564 \\
\hline Juniperus coahuilensis & 0.638 & 0.702 & 1.02 & 1.715 \\
\hline Juniperus deppeana & 0.564 & 0.669 & 0.214 & 0.255 \\
\hline Juniperus monosperma & 0.564 & 0.711 & 0.254 & 0.294 \\
\hline Juniperus osteosperma & 0.517 & 0.543 & 0.222 & 0.269 \\
\hline Juniperus scopulorum & 0.689 & 0.737 & 0.332 & 0.433 \\
\hline Olneya tesota & 0.449 & 0.419 & 0.843 & 0.914 \\
\hline Parkinsonia florida & 0.6 & 0.727 & 1.642 & 1.852 \\
\hline Parkinsonia microphylla & 0.393 & 0.45 & 0.61 & 0.757 \\
\hline Picea engelmannii & 0.498 & 0.605 & 0.165 & 0.126 \\
\hline Picea pungens & 0.65 & 0.762 & 0.892 & 0.787 \\
\hline Pinus aristata & 0.766 & 0.874 & 0.393 & 0.412 \\
\hline Pinus contorta & 0.47 & 0.733 & 0.464 & 0.242 \\
\hline Pinus edulis & 0.568 & 0.669 & 0.264 & 0.407 \\
\hline Pinus flexilis & 0.922 & 0.967 & 0.122 & 0.115 \\
\hline Pinus monophylla & 0.788 & 0.91 & 0.122 & 0.076 \\
\hline Pinus ponderosa & 0.705 & 0.823 & 0.156 & 0.247 \\
\hline Pinus strobiformis & 0.766 & 0.885 & 0.185 & 0.082 \\
\hline Populus angustifolia & 0.706 & 0.815 & 0.379 & 0.393 \\
\hline Populus tremuloides & 0.512 & 0.66 & 0.29 & 0.248 \\
\hline Prosopis glandulosa & 0.275 & 0.471 & 0.879 & 1.456 \\
\hline Prosopis velutina & 0.222 & 0.248 & 1.067 & 1.31 \\
\hline Pseudotsuga menziesii & 0.546 & 0.632 & 0.304 & 0.353 \\
\hline Quercus arizonica & 0.859 & 0.838 & 0.548 & 0.778 \\
\hline Quercus emoryi & 0.673 & 0.78 & 0.49 & 0.607 \\
\hline Quercus gambelii & 0.545 & 0.665 & 0.43 & 0.515 \\
\hline Quercus grisea & 0.823 & 0.901 & 0.362 & 0.315 \\
\hline Quercus havardii & 0.739 & 0.866 & 1.107 & 0.878 \\
\hline
\end{tabular}




\begin{tabular}{|c|c|c|c|c|}
\hline \multirow{2}{*}{$\begin{array}{l}\text { Species } \\
\text { Time Period }\end{array}$} & \multicolumn{2}{|c|}{$\begin{array}{c}\text { Vulnerability } \\
\text { score }\end{array}$} & \multicolumn{2}{|c|}{ Potential score } \\
\hline & 2050 & 2100 & 2050 & 2100 \\
\hline Yucca brevifolia & 0.691 & 0.894 & 0.846 & 0.748 \\
\hline \multicolumn{5}{|l|}{ Shrubs } \\
\hline Acacia constricta & 0.473 & 0.549 & 0.317 & 0.24 \\
\hline Acacia greggii & 0.668 & 0.835 & 0.692 & 0.75 \\
\hline Ambrosia deltoidea & 0.846 & 0.817 & 0.277 & 0.282 \\
\hline Ambrosia dumosa & 0.593 & 0.69 & 0.374 & 0.391 \\
\hline Amelanchier alnifolia & 0.423 & 0.465 & 0.567 & 0.773 \\
\hline Amelanchier utahensis & 0.592 & 0.597 & 0.415 & 0.497 \\
\hline Arctostaphylos patula & 0.763 & 0.752 & 0.36 & 0.655 \\
\hline Arctostaphylos pringlei & 0.846 & 0.92 & 0.266 & 0.379 \\
\hline Arctostaphylos pungens & 0.652 & 0.818 & 0.377 & 0.343 \\
\hline Arctostaphylos uvaursi & 0.686 & 0.768 & 0.857 & 0.625 \\
\hline Artemisia arbuscula & 0.825 & 0.92 & 0.083 & 0.019 \\
\hline Artemisia bigelovii & 0.607 & 0.795 & 0.526 & 0.511 \\
\hline Artemisia filifolia & 0.549 & 0.747 & 1.175 & 1.412 \\
\hline Artemisia frigida & 0.591 & 0.626 & 0.368 & 0.43 \\
\hline Artemisia nova & 0.586 & 0.747 & 0.269 & 0.226 \\
\hline Artemisia tridentata & 0.486 & 0.59 & 0.095 & 0.067 \\
\hline Atriplex canescens & 0.325 & 0.524 & 0.701 & 0.826 \\
\hline Atriplex confertifolia & 0.475 & 0.606 & 0.306 & 0.231 \\
\hline Atriplex corrugata & 0.822 & 0.831 & 0.288 & 0.187 \\
\hline Atriplex gardneri & 0.732 & 0.764 & 0.249 & 0.211 \\
\hline Atriplex hymenelytra & 0.783 & 0.876 & 0.173 & 0.432 \\
\hline Atriplex obovata & 0.271 & 0.498 & 2.215 & 2.657 \\
\hline Atriplex polycarpa & 0.678 & 0.718 & 0.405 & 0.523 \\
\hline Baccharis sarothroides & 0.666 & 0.678 & 0.381 & 1.081 \\
\hline Canotia holacantha & 0.819 & 0.992 & 0.454 & 0.461 \\
\hline Ceanothus greggii & 0.938 & 0.983 & 0.121 & 0.087 \\
\hline Cercocarpus intricatus & 0.95 & 0.924 & 0.079 & 0.182 \\
\hline Cercocarpus ledifolius & 0.775 & 0.884 & 0.158 & 0.085 \\
\hline Cercocarpus montanus & 0.67 & 0.71 & 0.619 & 0.77 \\
\hline Chrysothamnus depressus & 0.907 & 0.885 & 0.276 & 0.355 \\
\hline Chrysothamnus greenei & 0.773 & 0.916 & 0.423 & 0.466 \\
\hline Chrysothamnus viscidiflorus & 0.72 & 0.926 & 0.079 & 0.025 \\
\hline Coleogyne ramosissima & 0.66 & 0.868 & 0.806 & 0.786 \\
\hline Encelia farinosa & 0.781 & 0.913 & 0.247 & 0.182 \\
\hline Ephedra nevadensis & 0.589 & 0.704 & 0.654 & 0.706 \\
\hline
\end{tabular}




\begin{tabular}{|c|c|c|c|c|}
\hline \multirow{2}{*}{$\begin{array}{l}\text { Species } \\
\text { Time Period }\end{array}$} & \multicolumn{2}{|c|}{$\begin{array}{c}\text { Vulnerability } \\
\text { score }\end{array}$} & \multicolumn{2}{|c|}{ Potential score } \\
\hline & 2050 & 2100 & 2050 & 2100 \\
\hline Ephedra torreyana & 0.329 & 0.496 & 1.068 & 1.335 \\
\hline Ephedra trifurca & 0.384 & 0.574 & 1.009 & 1.213 \\
\hline Ephedra viridis & 0.523 & 0.638 & 0.366 & 0.466 \\
\hline Ericameria linearifolia & 0.903 & 0.988 & 0.507 & 0.115 \\
\hline Ericameria nauseosa & 0.779 & 0.843 & 0.232 & 0.244 \\
\hline Eriogonum fasciculatum & 0.917 & 0.969 & 0.221 & 0.197 \\
\hline Eriogonum wrightii & 0.718 & 0.749 & 0.63 & 1.132 \\
\hline Fallugia paradoxa & 0.536 & 0.688 & 0.728 & 0.799 \\
\hline Flourensia cernua & 0.905 & 0.884 & 0.546 & 1.09 \\
\hline Fouquieria splendens & 0.315 & 0.392 & 1.196 & 1.529 \\
\hline Garrya flavescens & 0.908 & 0.883 & 0.142 & 0.387 \\
\hline Garrya wrightii & 0.79 & 0.869 & 0.263 & 0.419 \\
\hline Grayia spinosa & 0.725 & 0.758 & 0.437 & 0.376 \\
\hline Gutierrezia microcephala & 0.733 & 0.797 & 0.322 & 0.652 \\
\hline Gutierrezia sarothrae & 0.437 & 0.591 & 0.301 & 0.365 \\
\hline Hymenoclea salsola & 0.823 & 0.877 & 0.341 & 0.49 \\
\hline Juniperus communis & 0.462 & 0.61 & 0.339 & 0.274 \\
\hline Krascheninnikovia lanata & 0.685 & 0.754 & 0.335 & 0.252 \\
\hline Larrea tridentata & 0.398 & 0.576 & 0.89 & 1.227 \\
\hline Lupinus argenteus & 0.579 & 0.928 & 0.748 & 0.651 \\
\hline Lycium andersonii & 0.791 & 0.736 & 1.482 & 1.734 \\
\hline Lycium pallidum & 0.98 & 0.973 & 0.121 & 0.192 \\
\hline Mahonia repens & 0.485 & 0.591 & 0.659 & 0.655 \\
\hline Menodora spinescens & 0.981 & 0.982 & 0.53 & 0.408 \\
\hline Mimosa aculeaticarpa & 0.697 & 0.839 & 0.398 & 0.464 \\
\hline Opuntia basilaris & 0.919 & 0.933 & 0.147 & 0.072 \\
\hline Opuntia engelmannii & 0.693 & 0.837 & 0.331 & 0.37 \\
\hline Parthenium incanum & 0.602 & 0.793 & 1.492 & 1.445 \\
\hline Paxistima myrsinites & 0.541 & 0.428 & 0.682 & 1.139 \\
\hline Picrothamnus desertorum & 0.885 & 0.981 & 0.185 & 0.029 \\
\hline Prunus fasciculata & 0.825 & 0.953 & 0.178 & 0.552 \\
\hline Prunus virginiana & 0.461 & 0.569 & 0.616 & 0.648 \\
\hline Purshia mexicana & 0.574 & 0.691 & 0.543 & 0.73 \\
\hline Purshia stansburiana & 0.799 & 0.738 & 0.395 & 0.696 \\
\hline Purshia tridentata & 0.557 & 0.761 & 0.457 & 0.376 \\
\hline Quercus turbinella & 0.71 & 0.836 & 0.337 & 0.379 \\
\hline Rhus microphylla & 0.763 & 0.775 & 0.522 & 0.634 \\
\hline
\end{tabular}




\begin{tabular}{|c|c|c|c|c|}
\hline \multirow{2}{*}{$\begin{array}{l}\text { Species } \\
\text { Time Period }\end{array}$} & \multicolumn{2}{|c|}{$\begin{array}{c}\text { Vulnerability } \\
\text { score }\end{array}$} & \multicolumn{2}{|c|}{ Potential score } \\
\hline & 2050 & 2100 & 2050 & 2100 \\
\hline Rhus ovata & 0.995 & 0.998 & 0.044 & 0.006 \\
\hline Rhus trilobata & 0.699 & 0.737 & 0.282 & 0.382 \\
\hline Ribes cereum & 0.652 & 0.69 & 0.459 & 0.553 \\
\hline Ribes montigenum & 0.697 & 0.879 & 0.314 & 0.105 \\
\hline Robinia neomexicana & 0.712 & 0.832 & 0.196 & 0.261 \\
\hline Rosa woodsii & 0.811 & 0.864 & 0.277 & 0.239 \\
\hline Salazaria mexicana & 0.882 & 0.935 & 0.385 & 0.221 \\
\hline Salix geyeriana & 0.728 & 0.812 & 0.794 & 0.47 \\
\hline Sarcobatus vermiculatus & 0.602 & 0.766 & 0.322 & 0.222 \\
\hline Shepherdia canadensis & 0.215 & 0.345 & 1.454 & 1.047 \\
\hline Simmondsia chinensis & 0.302 & 0.515 & 2.333 & 2.311 \\
\hline Suaeda moquinii & 0.383 & 0.515 & 1.481 & 1.263 \\
\hline Symphoricarpos albus & 0.71 & 0.801 & 0.603 & 0.639 \\
\hline Symphoricarpos oreophilus & 0.641 & 0.774 & 0.24 & 0.194 \\
\hline Symphoricarpos rotundifolius & 0.685 & 0.722 & 0.794 & 0.935 \\
\hline Tetradymia glabrata & 0.91 & 0.971 & 0.44 & 0.3 \\
\hline Tetradymia spinosa & 0.708 & 0.908 & 0.294 & 0.101 \\
\hline Vaccinium myrtillus & 0.646 & 0.784 & 0.509 & 0.336 \\
\hline Vaccinium scoparium & 0.626 & 0.783 & 0.42 & 0.247 \\
\hline Yucca angustissima & 0.665 & 0.816 & 0.402 & 0.45 \\
\hline Yucca baccata & 0.499 & 0.643 & 0.453 & 0.717 \\
\hline Yucca elata & 0.542 & 0.708 & 0.618 & 0.88 \\
\hline Yucca glauca & 0.599 & 0.728 & 0.212 & 0.166 \\
\hline Yucca schidigera & 0.981 & 0.999 & 0.13 & 0.069 \\
\hline Ziziphus obtusifolia & 0.486 & 0.681 & 1.77 & 4.019 \\
\hline \multicolumn{5}{|l|}{ Grasses } \\
\hline Achnatherum hymenoides & 0.503 & 0.639 & 0.187 & 0.218 \\
\hline Achnatherum speciosum & 0.85 & 0.899 & 0.134 & 0.061 \\
\hline Achnatherum thurberianum & 0.818 & 0.974 & 0.119 & 0.034 \\
\hline Bouteloua curtipendula & 0.676 & 0.764 & 0.277 & 0.45 \\
\hline Bouteloua eriopoda & 0.702 & 0.814 & 0.886 & 1.039 \\
\hline Bouteloua gracilis & 0.543 & 0.668 & 0.146 & 0.17 \\
\hline Bouteloua hirsuta & 0.68 & 0.706 & 0.447 & 0.766 \\
\hline Dasyochloa pulchella & 0.555 & 0.633 & 2.104 & 2.354 \\
\hline Elymus elymoides & 0.748 & 0.807 & 0.177 & 0.223 \\
\hline Elymus glaucus & 0.448 & 0.481 & 1.101 & 0.689 \\
\hline Elymus trachycaulus & 0.467 & 0.58 & 0.72 & 0.44 \\
\hline
\end{tabular}




\begin{tabular}{l|r|r|r|r}
\hline & \multicolumn{2}{|c|}{$\begin{array}{c}\text { Vulnerability } \\
\text { score }\end{array}$} & \multicolumn{2}{c}{ Potential score } \\
\hline Species & $\mathbf{2 0 5 0}$ & $\mathbf{2 1 0 0}$ & $\mathbf{2 0 5 0}$ & $\mathbf{2 1 0 0}$ \\
\hline \multicolumn{1}{c|}{ Time Period } & 0.807 & 0.911 & 0.689 & 0.791 \\
\hline Festuca arizonica & 0.72 & 0.876 & 0.569 & 0.43 \\
\hline Festuca brachyphylla & 0.679 & 0.732 & 0.499 & 0.265 \\
\hline Festuca idahoensis & 0.563 & 0.679 & 0.659 & 0.491 \\
\hline Festuca thurberi & 0.654 & 0.723 & 0.291 & 0.374 \\
\hline Hesperostipa comata & 0.467 & 0.554 & 0.98 & 1.566 \\
\hline Hilaria belangeri & 0.623 & 0.746 & 0.783 & 0.641 \\
\hline Hordeum jubatum & 0.622 & 0.706 & 0.858 & 1.071 \\
\hline Koeleria macrantha & 0.666 & 0.889 & 0.11 & 0.023 \\
\hline Leymus cinereus & 0.685 & 0.67 & 0.525 & 0.66 \\
\hline Muhlenbergia emersleyi & 0.782 & 0.871 & 0.611 & 0.731 \\
\hline Muhlenbergia montana & 0.43 & 0.418 & 1.196 & 1.809 \\
\hline Muhlenbergia porteri & 0.599 & 0.723 & 0.562 & 0.56 \\
\hline Pascopyrum smithii & 0.557 & 0.745 & 0.311 & 0.331 \\
\hline Pleuraphis jamesii & 0.838 & 0.946 & 1.001 & 0.898 \\
\hline Pleuraphis mutica & 0.837 & 0.969 & 0.644 & 0.406 \\
\hline Pleuraphis rigida & 0.737 & 0.761 & 0.575 & 0.944 \\
\hline Poa fendleriana & 0.365 & 0.541 & 0.123 & 0.067 \\
\hline Poa secunda & 0.773 & 0.849 & 0.212 & 0.2 \\
\hline Schizachyrium scoparium & 0.414 & 0.677 & 0.772 & 0.71 \\
\hline Sporobolus airoides & 0.78 & 0.915 & 0.513 & 0.495 \\
\hline Sporobolus cryptandrus & 0.887 & 0.95 & 0.959 & 0.621 \\
\hline Sporobolus flexuosus & & & \\
\hline & & & \\
\hline
\end{tabular}




\section{Appendix B Assessment Results for the 166 Plant Species: Spatial Models Figures 1 to 166.}

http://pubs.usgs.gov/of/2012/1020/of2012-1020_appendix_b/: Assessment Results for the 166 Plant Species: Spatial Models Figures 1 to 166. The data are presented as a single large PDF; as one PDF each for trees, shrubs, and grasses; and as a set of 166 single-page PDFs - one for each of the species (2.6 GB total). 